ARTHUR WELLE

\title{
ADAPTAÇÃO E USO DE FERRAMENTA DE VISUALIZAÇÃO PARA O ESTUDO DO CONJUNTO DE TRATADOS ENTRE OS MEMBROS DA ONU
}

CAMPINAS, 2012 


\title{
UNIVERSIDADE ESTADUAL DE CAMPINAS \\ INSTITUTO DE FILOSOFIA E CIÊNCIAS HUMANAS
}

\author{
ARTHUR WELLE
}

\section{ADAPTAÇÃO E USO DE FERRAMENTA DE VISUALIZAÇÃO PARA O ESTUDO DO CONJUNTO DE TRATADOS ENTRE OS MEMBROS DA ONU}

Dissertação de Mestrado apresentada ao Programa de Pós-Graduação do Instituto de Filosofia e Ciências Humanas da Universidade Estadual de Campinas como requisito parcial para a obtenção do título de Mestre em Relações Internacionais na área de concentração Instituições, Processos e Atores.

Orientador: Prof. Dr. Reginaldo Carmello Corrêa de Moraes

CAMPINAS

2012 
W458a

Welle, Arthur, 1983-

Adaptação e uso de ferramenta de visualização para o estudo do conjunto de tratados entre os membros da ONU / Arthur Welle. - - Campinas, SP : [s. n.], 2012.

Orientador: Reginaldo Carmello Corrêa de Moraes. Dissertação (mestrado) - Universidade Estadual de Campinas, Instituto de Filosofia e Ciências Humanas.

1. Nações Unidas. 2. Tratados. 3. Visualização. 4. Relações internacionais. 5. Epistemologia. I. Moraes, Reginaldo C. Corrêa de (Reginaldo Carmello Corrêa de), 1950- II. Universidade Estadual de Campinas. Instituto de Filosofia e Ciências Humanas. III.Título.

\section{Informação para Biblioteca Digital}

Título em Inglês: Investigating the UN members treaty collection:

adaptation and use of a visualization tool

Palavras-chave em inglês:

United Nations

Treaties

Visualization

International relations

Epistemology

Área de concentração: Instituição, Processos e Atores

Titulação: Mestre em Relações Internacionais

Banca examinadora:

Reginaldo Carmello Corrêa de Moraes [Orientador]

Shiguenoli Miyamoto

Cecilia Carmen Pontes Rodrigues

Data da defesa: 16-08-2012

Programa de Pós-Graduação: Relações Internacionais San Tiago Dantas (UNESP, UNICAMP, PUC-SP) 
Universidade Estadual de Campinas

Instituto de Filosofia e Ciências Humanas

Programa de Pós-Graduação em Relações Internacionais

A Comissão Julgadora dos trabalhos de Defesa de Dissertação de Mestrado, em sessão pública realizada em 16 de agosto de 2012, considerou o candidato Arthur Welle aprovado.

Este exemplar corresponde à redação final da Dissertação defendida e aprovada pela Comissão Julgadora.

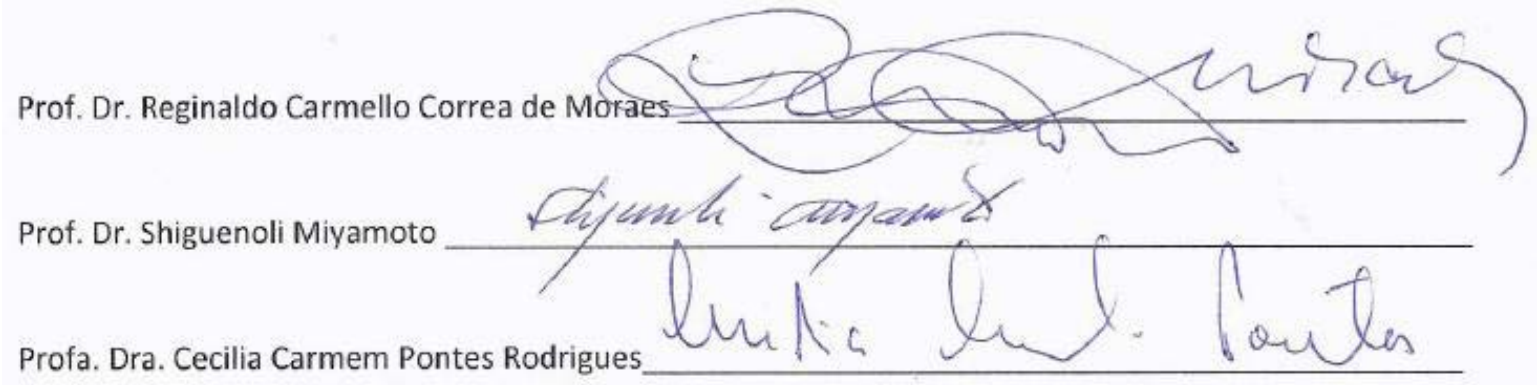

\section{Campinas}

Agosto de 2012 


\section{AGRADECIMENTOS}

Agradeço a toda a minha família.

Ao professor Reginaldo Moraes pela orientação ao longo deste trabalho.

À professora Cecília Pontes pela leitura cuidadosa e comentários críticos feitos ao texto.

Agradecimento especial ao professor Shiguenoli Miyamoto, que não só me iniciou nos estudos internacionais durante a graduação como foi fundamental para a decisão de seguir em frente com este projeto quando ele ainda era só uma vaga ideia.

Aos amigos, professores e funcionários do programa de pós-graduação "San Tiago Dantas" por todas as discussões e pelo aprendizado.

Ao Diego e ao Vinícios da Empresa Júnior de Computação da Unicamp pelo apoio na construção das ferramentas, e em especial ao desenvolvedor José pelo trabalho cheio de percalços até que chegássemos ao programa final.

Aos funcionários do Treaty Section do Office of Legal Affairs das Nações Unidas, pelo valioso suporte na pesquisa.

Aos amigos Marcelo, Otávio e Bruno pela ajuda na aventura de aprender programação.

Aos amigos de longa data da nossa famosa república: Matheus, Pedro, Juliano, Ricardo, Valdeni, Mário, Elsa, Márcio, Bernardus, Gustavo, Charlie, Yamashiro, Marcos, Robert, Gleidson, Robson, e todos ao novos membros desta.

Aos amigos de jogatina, Daniel, Mari, Caio, Alice e Jerê.

À Elisa pelo amor, pelo carinho, pelo renovado incentivo e ainda por corrigir meu português.

E finalmente, à Fundação de Amparo a Pesquisa do Estado de São Paulo (Fapesp) pela bolsa concedida para realização desta pesquisa. 


\section{RESUMO}

O presente projeto consiste numa pesquisa exploratória centralizada sobre os padrões gerais do conjunto de tratados registrados pelo Secretariado das Nações Unidas seguindo as atribuições do Artigo 102 da Carta de fundação da entidade. Especificamente pretende adaptar e aplicar em tal conjunto ferramentas de visualização gráfica apoiadas por computador, que visam à exploração, descoberta e comunicação de fatores relevantes para o estudo das Relações Internacionais. As ferramentas permitem a manipulação das variáveis presentes neste banco de dados tais como datas, atores e assuntos dos tratados. As representações visuais geradas, por sua vez, permitem a análise de diferentes dimensões deste conjunto, tais como a distribuição temporal, espacial e qualitativa de uma seleção de tratados escolhida pelo usuário. Isto permite que padrões antes escondidos possam ser trazidos a tona. Também tem papel central nesta pesquisa uma discussão dos limites de tal ferramenta, elencando e discutindo os procedimentos e características que podem influenciar o resultado final da análise.

Palavras-chave: Nações Unidas, Tratados, Visualização, Relações Internacionais, Epistemologia. 


\begin{abstract}
The present project consists in an exploratory research centralized on the main patterns of the database of treaties registered by the Secretariat of the United Nations due to its obligations stated at Article 102 of the organization's Charter. More specifically its purpose is to adapt and apply computer visualization tools to this database. The visualization tools developed here aim the exploration, discovery and communication of relevant features to International Relations research. These tools allow the manipulation of selected variables in the database, such as dates, participant actors and treaties subject. The visual representations furthermore facilitate the analysis of several dimensions of subsets chosen by the user, such as qualitative, temporal and geographic distribution. These proceedings help bring hidden patterns to the surface. The discussion about the limits of these tools has also a central place on this research. We listed and analyzed the characteristics and steps which could have a relevant impact on the final result.
\end{abstract}

Key words: United Nations, Treaties, Visualization, International Relations, Epistemology. 


\section{LISTA DE FIGURAS.}

Figura 2.1. Tela inicial da visualização radial, com os controles do banco de dados.

Figura 2.2. $\quad$ Representação de todos os tratados bilaterais do Brasil, 1900- 30 2000.

Figura 2.3. Todos os tratados bilaterais categorizado nos assuntos Raw Materials Trade e General Trade, 1900-2000.

Figura 2.4. Interações com a visualização.

Figura 2.5. Caixa de informações sobre cada tratado. 35

Figura 2.6. Exemplo de agregação das linhas por fator hierárquico. 35

Figura 2.7. Tela Inicial da ferramenta de geração de relatório. 36

Figura 2.8. Mapa da distribuição espacial das quantidades de tratados 37 bilaterais dos quais o Brasil é parte, 1900-2000.

Figura 2.9. Gráfico de barras mostrando a distribuição temporal das quantidades de tratados dos quais o Brasil é parte, 1900-2000.

Figura 2.10. Tabela A mostrando os atores com quem o ator selecionado (Brasil) faz mais tratados e suas porcentagens. Tabela B mostrando os assuntos mais freqüentemente relacionados aos tratados celebrados pelo Brasil; 1900-2000.

Figura 3.1. Quantidade de tratados em vigor e extintos por ano, com linha de tendência, 1945-2008.

Figura 3.2. Número médio de tratados bilaterais registrados no UNTS por 55 ano por Estado Membro da ONU, 1945-2008.

Figura 3.3. Quantidade de tratados bilaterais de A) Atores territoriais entre si; B) Atores territoriais e Organizações Internacionais; C) Organizações Internacionais entre si; 1945-2007.

Figura 3.4. Aumento do número de Estados Membros da ONU, 1945-2011. 62

Figura 3.5. Distribuição geográfica e temporal da filiação à ONU. 65

Figura 4.1. Exemplos de evolução temporal de tratados por ator, 1945- 76 2008.

Figura 4.2. Quantidade de tratados bilaterais americanos, do mundo e 79 porcentagem dos EUA no total mundial, 1945-2007. 
Figura 4.3. Distribuição espacial dos tratados Argentina, 1945-2008. 80

Figura 4.4. Distribuição espacial dos tratados da China, 1945-2008. 80

Figura 4.5. Distribuição espacial dos tratados do BIRD, 1945-2008. 81

Figura 4.6. Distribuição espacial dos tratados da IDA, 1945-2008. $\quad$ D

Figura 4.7. Distribuição espacial dos tratados da URSS, 1945-1991. 82

Figura 4.8. Exemplos de evolução temporal de tratados por assunto relativo, 84 1945-2008.

Figura 4.9. Evolução dos preços internacionais do petróleo (ajustados para 85 2011) e das quantidade de tratados relacionados aos assuntos Petroleum, Gas e Fuel, 1945-2007.

Figura 4.10. Evolução das quantidades de tratados relacionados aos temas 87 Trade e Taxation \& Investments. 1945-2007.

Figura 4.11. Distribuição dos tratados relacionados aos assuntos General 88 Trade e Investments Guarantees.

Figura 4.12. Distribuição espacial dos tratados do Brasil, 01/01/1945 - 89 01/04/1964.

Figura 4.13. Distribuição espacial dos tratados do Brasil, 01/04/1964 - 90 01/04/1985.

Figura 4.14. Distribuição espacial dos tratados do Brasil, 01/04/1985 - 90 31/12/2008.

Figura 4.15. Evolução da quantidade total de tratados do Brasil, e de alguns 92 assuntos selecionado, 1945-2008. 


\section{ABREVIAÇÕES.}

Artigo 102: Artigo 102 da Carta das Nações Unidas.

BIRD: Banco Internacional de Reconstrução e Desenvolvimento. Braço do Banco Mundial.

Carta: Carta das Nações Unidas de 1945.

CV ou Convenção de Viena 1969: Convenção de Viena sobre o Direito dos Tratados, 1969 (Vienna Convention on the Law of Treaties).

Convenção de Viena 1986: Convenção de Viena sobre o Direito dos Tratados entre Estados e Organizações Internacionais ou entre Organizações Internacionais, 1986 (Vienna Convention on the Law of Treaties between States and International Organizations or between International Organizations).

EUA: $\quad$ Estados Unidos da América.

GATT: Acordo Geral de Tarifas e Comércio (General Agreement on Tariffs and Trade).

IDA: International Development Association. Braço do Banco Mundial de empréstimos para o desenvolvimento, concentrados nos países mais pobres.

OI: $\quad$ Organizações Internacionais.

OLA: $\quad$ Escritório de assuntos Legais da ONU; (Office of Legal Affairs).

OMC: $\quad$ Organização Mundial do Comércio.

Online Collection: United Nations Treaty Series Online Collection.

ONU: $\quad$ Organização das Nações Unidas.

Regulações: Regulações para dar efeito ao Artigo 102 da Carta das Nações Unidas (Regulations to give effect to Article 102 of the Charter of the United Nations) (ver citação completa em ONU[c]).

Repertory of Practice: Repertório das Práticas dos Órgãos da ONU (Repertory of Practice of United Nations Organs) (ver citação completa em ONU[h]).

Secretariado: Secretariado-Geral da Organização das Nações Unidas.

Summary of Practice: Summary of Practice of the Secretary-General as Depositary of Multilateral Treaties (ONU[g], 1999). 
Treaty Section: Treaty Section, Office of Legal Affairs of the United Nations.

UNCTAD: Conferência das Nações Unidas sobre Comércio e Desenvolvimento (acrônimo de United Nations Conference on Trade and Development).

UNICEF: Fundo das Nações Unidas para a Criança; agência especializada da ONU (acrônimo de United Nations Children's Fund).

UNTS: $\quad$ United Nations Treaty Series. Principal publicação da OLA, é composta pela íntegra da maioria dos tratados assinados por qualquer um dos Membros da ONU, em cumprimento ao artigo 102 da Carta das Nações Unidas.

UNTC: $\quad$ United Nations Treaty Collection, departamento do OLA.

URSS: União das Repúblicas Socialistas Soviéticas.

WTI: $\quad$ World Treaty Index (www.worldtreatyindex.com) 


\section{SUMÁRIO}

INTRODUÇÃO

CAPÍTULO 1. Tratados, seu estudo e opção metodológica deste trabalho 7

1.1. Tratados

$\begin{array}{ll}\text { 1.2. A opção metodológica deste trabalho } & 17\end{array}$

CAPÍTULO 2. Ferramentas 25

2.1. Introdução 25

2.2. Descrição das ferramentas $\quad 27$

2.2.1. Ferramenta de representação radial 27

2.2.2. Ferramenta de geração de relatório, gráfico temporal e mapa 36

CAPÍTULO 3. Os Dados 41

3.1. Introdução 41

3.2. Tratados 42

3.2.1. O Artigo 102 da Carta das Nações Unidas 42

3.2.2. Definição de tratados e acordos internacionais 44

3.2.3. Poder de celebrar tratados 46

3.2.4. Consentimento de obrigar-se por um tratado (consent to be 48 bound)

3.2.5. Entrada em vigor e outras ações referentes a tratados. 49

3.2.6. Duração e extinção de um tratado 51

3.2.7. Registro dos tratados junto ao Secretariado da ONU 52

3.2.8. Arquivamento e publicação dos tratados pelo Secretariado 56

3.2.9. Definição do(s) assunto(s) e da lateralidade dos tratados 58

3.3. Atores internacionais 59

3.3.1. Critérios para filiação à ONU. 
3.3.2. Evolução do número de Estados Membros da ONU e sua dispersão.

3.3.3. Tipos de atores internacionais presentes no banco de dados 63

3.3.4. Mudanças no conjunto de atores relevantes para a 66 representação visual e a sucessão aos tratados

3.4. Procedimentos de transformação dos dados. 69

3.4.1. Compilação de tratados 70

3.4.2. Compilação de atores 71

CAPÍTULO 4. Análise experimental e conclusão 73

4.1. Alguns exemplos de uso das ferramentas 74

4.2. Conclusão 93

$\begin{array}{ll}\text { BIBLIOGRAFIA } & 97\end{array}$

$\begin{array}{ll}\text { ANEXOS } & 109\end{array}$

Anexo I - Lista de atores e quantidades de tratados para cada um deles no 109 banco de dados do Treaty Section do Office of Legal Affairs da ONU (1900-2010).

Anexo II - Lista de assuntos relacionados e quantidades de tratados para cada um deles no banco de dados do Treaty Section do Office of Legal Affairs da ONU (1900-2010).

Anexo III - Lista de atores e quantidades de tratados para cada um deles no banco de dados do World Treaty Index (1900-2000).

Anexo IV - Lista de assuntos relacionados suas descrições, e quantidades de tratados, no banco de dados do World Treaty Index (19002000). 


\section{INTRODUÇÃO}

Atores internacionais interagem, o que chamamos de relações internacionais. Algumas interações são conflitivas (como nas guerras), outras competitivas (como em algumas áreas de comércio), e outras cooperativas (como em muitos casos de assistência mútua). Ao tentar delinear uma figura geral das interações internacionais, o estudioso usa seu aparato teórico, seus conhecimentos prévios e os indícios empíricos que consegue recolher dessas interações. No caso dos conflitos, ele observa quais áreas foram disputadas, os gastos militares e toda informação que ele possa considerar útil para compor o acontecimento e para embasar seu entendimento e sua interpretação. No caso das competições comerciais, ele pode elencar um sem número de informações econômicas, tais como pauta exportadora e destino da exportação. Ao estudar cooperação, ele pode elencar e analisar discursos, pode pinçar quais os tratados assinados, pode verificar quais foram as ações conjuntas. A depender do objetivo da pesquisa, do aparato teórico utilizado, do objeto desta pesquisa, o estudioso atribuirá pesos diferentes a informações diferentes. Percebemos que um tratamento específico de um conjunto de dados que poderia ser relevante para muitos destes estudos era subutilizado: os conjuntos de tratados. Os tratados sempre tiveram a atenção das Relações Internacionais, mas muito pouco freqüentemente de um ponto de vista generalista e distante, usando o conjunto de tratados como fonte.

Tratados são um dos mais importantes indícios da interação entre atores internacionais; a interação expressa pelos tratados está normalmente, mas não exclusivamente, relacionada à cooperação entre nações. Alguns dos temas estudados pelas Relações Internacionais são refletidos com diferentes graus de intensidade nas ações dos atores internacionais por meio de tratados. O Secretariado Geral das Nações Unidas, de acordo com suas atribuições, registra e publica todos os tratados que entram em vigor para cada um de seus membros. Ao longo de seus mais de sessenta anos de atividades com este propósito, o total de tratados atualmente à disposição para consulta por qualquer cidadão é de aproximadamente 60 mil tratados bilaterais e 6 mil multilaterais, celebrados entre mais de 200 nações e aproximadamente mil organizações internacionais. 
O objetivo desta pesquisa é construir e avaliar ferramentas de suporte para a exploração e análise deste conjunto de tratados. As ferramentas escolhidas para fazê-lo de modo eficaz foram as visualizações de dados apoiadas por computador. Optamos pelas visualizações de informações por elas terem um longo histórico de uso nas ciências, ajudando na descoberta de características inerentes aos dados, permitindo manipulação e comparação de muitas variáveis, reduzindo a complexidade do conjunto e tornando evidente a estrutura por detrás desta grande quantidade de dados. Enfim, as visualizações ajudam no processo de descoberta de novos conhecimentos, e ainda na transmissão destes.

De maneira prática compilamos informações básicas dos tratados registrados no banco de dados da ONU, tais como datas de assinatura e de entrada em vigor, nome dos participantes do tratado, assunto relacionado ao tratado, e outras informações de registro. Essas informações são tomadas como variáveis do conjunto desses tratados e serão manipuladas pelas ferramentas. É possível, por exemplo, ver a representação de todos os tratados, de um certo país e em uma certa época, que têm como assunto o comércio. É possível acompanhar a distribuição espacial da seleção de tratados escolhidos por meio de um mapa, ou a tendência nas quantidades destes ao longo do tempo com um gráfico de barras; ou ainda é possível comparar a distribuição de dois atores através da visualização radial.

Estes são exemplos de explorações feitas sobre os dados através do uso das ferramentas. Explorar é uma atitude muito comum aos cientistas de várias áreas, e aqui é feita com base em informações (tratados) que transformamos em dados estruturados. Criamos ferramentas que permitem não só a manipulação dos dados mas que tem ainda o objetivo de representar estas informações de tal maneira que a interpretação da estrutura e dinâmica de suas características relevantes seja facilitada. O usuário é convidado a explorar as possibilidades das relações entre as variáveis dos dados e as representações voltadas para a expressão de diferentes dimensões destes dados e, com a ajuda de seus conhecimentos prévios do mundo da política internacional, interpretar os padrões do conjunto de tratados que toma conhecimento.

No entanto, atingir este objetivo não é tarefa fácil, e há alguns perigos no caminho. Há uma longa lista de interferências e ruídos que cumulativamente dificultam 
ligar o que ocorre na política internacional com a representação visual de um conjunto de tratados. Os atores internacionais agem de diferentes maneiras, há outras formas de cooperar que não tratados, há diferentes tipos de tratados, muitos deles não são registrados, há erros nos registros, há dificuldade no tratamento dos dados por serem incompletos e não padronizados, o processo legal evolui e se modifica com o tempo, as formas de representação visual escolhidas são sempre obrigadas a conter em si processos que distorcem os dados. Enfim, há uma série de procedimentos que, de maneiras diferentes, influenciam na formação dos dados e de sua representação e que assim irão restringir as possíveis interpretações desses dados. A ligação destas pontas, a política internacional e a representação do conjunto de tratados, não é trivial.

Deste modo, tão ou mais importante do que o próprio processo de pensar e construir estas ferramentas, se tornou a necessidade de dar bases para avaliar corretamente o resultado final de uso destas ferramentas e seus limites. Para isso, tentamos esmiuçar criticamente no corpo da dissertação os procedimentos adotados em cada etapa, desde a escolha do uso de um tratado por um ator internacional, passando pela sua realização, seu registro, os procedimentos de indexação do secretariado, os procedimentos de seleção e compilação que utilizamos para transformar estes dados em dados manipuláveis pela ferramenta, e finalmente os procedimentos de representação produzidos pelas ferramentas e as possíveis análises feitas pelo usuário final das ferramentas. Análoga a uma crítica de fontes, este trabalho visa balizar uma avaliação das possibilidades e limites de uso das ferramentas propostas. E, ao mesmo tempo, ao descrever em minúcias todos os passos relevantes, dá ao leitor as ferramentas para que ele faça sua própria análise crítica.

Ainda assim, cremos que as ferramentas apresentadas podem ser bastante úteis para aquelas análises que tenham o devido cuidado ao utilizá-las. A exploração parcimoniosa destes dados empíricos por meio de sua representação visual pode ajudar na geração de conhecimento novo ou na criação de novas questões. A opção por uma análise mais distanciada dos dados usados por estas ferramentas sem dúvida limita seu uso, mas é importante lembrar que esta ferramenta é pensada como uma entre outras. Dado seu recorte e suas limitações, ela só pode apoiar o analista na execução de certas tarefas de uma certa 
maneira, ficando a seu cargo, como tem sido o padrão clássico da disciplina, as tarefas de análise social e política contextualizada.

A pesquisa pode ser dividida nas seguintes tarefas: a) compilar o banco de dados de tratados da ONU; b) pensar e construir as ferramentas de representação destes dados; c) fazer uma análise crítica destas ferramentas, de suas possibilidades e de seus limites.

No Capítulo 1 descrevemos o uso dos tratados como forma de interação entre atores internacionais, seu uso como fonte em estudos de Relações Internacionais sob diferentes visões, e em particular aquela visão que privilegia como base um olhar do conjunto geral de tratados. Discutem-se também aqui os possíveis problemas da opção metodológica deste projeto.

No Capítulo 2, após uma apresentação do uso de representações como ferramenta de estudos, descrevemos as ferramentas propostas. Explicitamos quais são os critérios das ferramentas, quais são os procedimentos para sua construção, como elas transformam os dados e quais são as conseqüências da utilização dessas ferramentas para a análise dos dados. São duas as principais ferramentas propostas. A primeira produz uma visualização radial dos dados, e a segunda um gerador de relatório dos dados selecionados que tem como pontos chave a geração de um mapa para análise da distribuição espacial dos tratados da seleção, de um gráfico de barras para análise da distribuição temporal dos tratados da seleção, e de tabelas com a lista dos atores mais relevantes na seleção e as respectivas porcentagens relativas.

No Capítulo 3 descrevemos em minúcias as características dos dados utilizados, como foram formados, como são manipulados pelo Secretariado da ONU, como são recolhidos e transformados em um segundo banco de dados apropriado à manipulação pelas ferramentas propostas. Dividimos este capítulo três partes que refletem discussões sobre a) tratados, b) atores, e c) transformações feitas nos dados durante a formação do banco de dados paralelo utilizado pelas ferramentas propostas.

O Capítulo 4 apresenta alguns usos experimentais das ferramentas propostas como teste de suas possibilidades. Concluímos retomando a discussão sobre as virtudes e os limites de seu uso. 
É preciso destacar ainda que durante o período de trabalho deste projeto um grupo da Michigan State University criou e disponibilizou uma base de dados de tratados do século XX, chamada de World Treaty Index ${ }^{1}$ (doravante WTI). Devido a dificuldades iniciais na compilação dos dados diretamente da ONU, utilizamos esta base de dados para trabalhar inicialmente com as ferramentas e algumas das figuras apresentadas aqui são feitas com base nestes dados.

As duas ferramentas podem ser acessadas online nos seguintes endereços:

http://www.treatypatterns.com:40760/view/

www.treatypatterns.biz.nf/TreatyMaps.html (utilize os navegadores Firefox ou Google Chrome)

\footnotetext{
${ }^{1}$ World Treaty Index é mantido pelos pesquisadores Michael Bommarito, Daniel Martin Katz e Paul Poast. A partir do fim de 2010 pôde ser acessado pelo site: www.worldtreatyindex.com .
} 


\section{CAPÍTULO 1: Tratados, seu estudo e opção metodológica deste trabalho}

São dois os objetivos centrais deste capítulo: apresentar os tratados como objeto de estudo das Relações Internacionais e definir o foco particular desta pesquisa. Como será detalhado ao longo deste trabalho, aqui se propõe ferramentas de análise de um conjunto de tratados por meio de representações visuais. A interpretação que se faz do significado dos tratados para as Relações Internacionais varia enormemente, dependendo do nível de análise, se mais ampla ou mais particular, dos pressupostos teóricos do analista e das informações de que este dispõe. Se a ferramenta produz uma representação da distribuição dos tratados norte-americanos com o resto do mundo, um primeiro analista pode ler aí um índice de afinidade identitária ou de amizade entre Nações. Outro pode percebê-la como reflexo das interações de cooperação e coordenação entre Nações. Um terceiro pode interpretá-la como os resultados de um exercício de hegemonia, ou ainda pode ver esta representação como nada mais do que o resultado da retórica política, considerando todos os tratados como um engodo completamente inócuo para as ações subseqüentes dos atores.

Vale notar que o fato de termos escolhido fazer, na primeira parte deste capítulo, uma apresentação de várias facetas dos tratados estudadas pelas Relações Internacionais não significa dizer que poderemos ver todas elas refletidas nas ferramentas propostas. A razão para incluir estes casos é permitir posteriormente definir em contexto os limites de sua aplicação.

$\mathrm{Na}$ segunda parte deste capítulo faremos a exposição da opção metodológica deste trabalho, isto é, o estudo dos tratados quantitativamente como contagem de eventos. Acompanha uma breve discussão dos principais problemas epistemológicos que esta opção acarreta, discussão esta que será posteriormente retomada no capitulo final deste texto.

\subsection{Tratados}

Tratados são instrumentos em forma escrita nos quais os atores internacionais demonstram seu comprometimento para com outro(s) ator(es). É uma atividade política racional com relação a fins. Com algumas variações importantes é uma atividade assumida como não coercitiva, isto é, nenhum ator é obrigado a entrar em tratado algum, e o ato de o 
fazer é conscientemente escolhido. É ainda uma forma de interação política imersa num contexto onde outras e diferentes formas de interação existem - em outras palavras, quando o ator internacional escolhe usar esta ferramenta (o tratado), o faz tendo um leque de outras opções em vista, tais como acordos políticos não escritos. Além disso, o uso de tratados é feito de acordo com regras, hábitos e rituais socialmente construídos e reconstruídos ao longo da história de seu uso.

Estes hábitos, regras e rituais socialmente construídos deram ao tratado de hoje suas características próprias, particulares ao contexto atual. Uma das mais importantes entre estas facetas, e que tem grandes implicações, é estar sujeito ao direito internacional contemporâneo (outra construção social com história). As características particulares que partem do direito internacional e definem a natureza do tratado contemporâneo serão discutidas em minúcias no terceiro capítulo deste trabalho; a título de exemplo, podemos citar aqui a forma do documento, o uso de uma tipologia de lateralidade (bilaterais, multilaterais), a prescrição de tratados secretos, e o rito envolvido.

É importante ter em mente que os tratados são em primeiro lugar atos políticos, atos estes que sofrem uma tentativa de limitação e codificação por parte do direito internacional. Sem dúvida que o direito internacional é importante para definir o que são os tratados e qual o uso deles, mas há outras características que são especialmente resultado da influência dos processos da política internacional. Alguns temas são objeto de tratados em períodos particulares e não em outros; alguns atores fazem muito mais tratados que outros, e a escolha de com quem fazer um tratado não é aleatória; em certos momentos há preponderância de tratados bilaterais, em outros são os multilaterais que se sobressaem. Em algum determinado ponto do século XX o meio ambiente se tornou um tema das relações entre Estados, e nesta esteira se tornou também um tema de tratados, logo não é trivial a distribuição destes ao longo do tempo e do espaço, sendo reflexo de um processo histórico e político. Do mesmo modo a divisão do planeta em dois blocos durante a Guerra Fria deixou marcas na distribuição dos tratados de muitas Nações, tornando difícil não esperar uma predominância de tratados intra-bloco. Alguns apontam que o fim desta bipolaridade significou um retorno à agenda multilateral durante a década de 1990, o que possivelmente será refletido em um aumento dos tratados multilaterais em detrimento dos bilaterais para 
este período. Os motivos para muitos padrões e características do conjunto de tratados, ainda que influenciados pelo direito internacional, só podem ser encontrados na política internacional e no desenvolvimento histórico dela.

Os tratados foram alvo de distintas teorizações partindo da disciplina de Relações Internacionais, seja os considerando em si mesmos, ou como parte de um conjunto maior de inter-relações dos atores internacionais. De maneira geral os debates refletem as visões dominantes das Relações Internacionais, opondo realistas e institucionalistas liberais. Grosso modo, realismo e institucionalismo liberal se diferenciam pelos entendimentos na capacidade de mudança do comportamento dos atores, pelas concepções sobre o poder e papel das instituições neste processo, e pela expectativa sobre a possibilidade de cooperação através destas instituições.

Para o realismo a organização não existe na esfera internacional, oposto ao que ocorre com as regras existentes dentro dos Estados. O espaço internacional é espaço da anarquia, e os atores buscam sua segurança e ganhos relativos. Num mundo assim, a cooperação é quase impossível à primeira vista, e instituições internacionais são fenômenos fadados ao fracasso e à irrelevância. Mas estes mesmos Estados insistem em se relacionar cooperativamente, e insistem em criar instituições como as Organizações Internacionais. A primeira explicação, aquela que se afasta menos dos pressupostos deste realismo, é afirmar que cooperação só existe quando há uma grande potência ou uma hegemonia por detrás desta, e que as instituições são em essência uma tentativa desses atores mais poderosos de manter sua posição, ou seja um instrumento de exercício de seu poder. Quando há uma Nação hegemônica esta faz tratados para tentar definir e manter o status-quo e solidificar ainda mais sua posição (ELSIG et al., 2008, pg.5).

O institucionalismo liberal, por sua vez, cujo maior expoente é Robert Keohane, também compartilha de muitos dos pressupostos realistas, mas se afasta deles ou os qualifica de tal modo que entende ser possível a cooperação mesmo num ambiente anárquico, mesmo se cada ator estiver somente em busca de benefícios próprios. Estes autores afirmam que as instituições podem ter um impacto significativo e modificar o comportamento dos atores, mesmo que limitado pelos interesses dos Estados, em especial pelos mais poderosos. Não é de surpreender, portanto, ser o institucionalismo liberal e não 
o realismo aquele que se interessa mais pelos tratados, pois estes podem ser entendidos como uma forma de instituição ou parte de um regime. A pergunta que mais intriga estes estudiosos é: como as instituições afetam o comportamento dos atores? A resposta a ela varia de autor para autor, especialmente por serem vários e ligeiramente diferentes os entendimentos da natureza dos processos envolvidos nas relações internacionais, da natureza das instituições internacionais e dos motivos para a existência dessas instituições. O mais correto seria falar em institucionalismos liberais, visto que cada autor apresenta uma resposta diferente para essas perguntas.

As explicações mais comuns da visão liberal-institucionalista para a existência dos tratados os apresentam como uma solução possível para os problemas de coordenação e cooperação, afirmando que os tratados trazem mecanismos de coerção e podem criar mecanismos de troca de informações, e que isto traz mais segurança para os atores escolherem o caminho da cooperação. Para eles, as instituições podem prover informação, reduzir os custos de transação, fazer com que os comprometimentos sejam mais críveis, estabelecer pontos focais para a coordenação, e, em geral facilitar a operação da reciprocidade. Se não houver interesse mútuo no regime, ou, de maneira específica, no tratado, ele não se realiza (ELSIG et al, 2008, p.5). Há aqueles, como Keohane (1984, apud: HELFER, 2005, p.1612), que crêem que as instituições contribuem para aumentar a cooperação num ambiente anárquico, permitindo que as partes tenham acesso à informação, façam a mediação de disputas entre si, e sancionem legalmente o não-cumprimento daquilo contratado.

Autores construtivistas argumentam que quaisquer que sejam os benefícios normativos que os tratados possam representar, estes devem ser entendidos como uma construção histórica, isto é, nem sempre estes benefícios existiram. Nas palavras de ReusSmit "It matters little whether, in an abstract rational sense, arbitration or multilateralism constitute a more efficient response to coordination and collaboration problems; what matters is that at particular historical moments states have deemed them the right responses"(REUS-SMIT, 1997, p.569). Denemark e Hoffmann (2006) afirmam que o uso dos tratados multilaterais teve um crescimento exponencial no final do século XIX e que para explicar este processo histórico é necessário perceber que a adoção destes como meio 
legítimo de interação depende justamente da quantidade de participantes. Quanto maior é o número de atores internacionais que utilizam os tratados maiores serão os retornos da utilização deste meio, e os custos de aprendizado serão decrescentes ao longo do tempo.

Os mecanismos de coerção que os tratados implicam têm pesos diferentes para cada autor. Alguns focam no poder de sanção instituída pelo próprio tratado, isto é, cláusulas de não cumprimento e de sanção legitimada em relação ao comportamento desviante do acordado. Outros apresentam junto do anterior o peso da reputação (GUZMAN, 2002; SIMONS et al., 2005; HELFER, 2005). O argumento é que os atores empenham no momento de fazer um tratado sua reputação, e deixar de cumprir um tratado destruiria a reputação não só com a outra parte contratante, mas com todos os outros atores do sistema que o tomariam como um ator não confiável. O peso deste fator deve variar conforme o assunto (GUZMAN, 2002, p.2), e nota-se que a reputação é algo bastante maleável, podendo ser que em determinado caso a reputação de ser um ator irracional ou instável seja vantajosa para o ator em questão (KEOHANE, 1997). Vale ainda lembrar que a reputação é algo relacional; se, por exemplo, todos os atores importantes do sistema violarem um dado tratado, talvez seja pouco vantajoso ficar com a reputação de cumpridor de tratados.

Raustiala (2004) sugere três conceitos analíticos para o estudo dos tratados: 'estrutura', 'legalidade', e 'substância'. Estrutura qualifica as instituições que foram criadas pelo tratado para monitorar, cobrar e punir um dado comportamento dos contratantes. Vários graus de estrutura são possíveis, desde nenhuma, até uma estrutura forte, independente e com poder de ações sobre as partes, tal como o tratado de criação da União Européia. Legalidade indica o grau de sujeição das regras e artigos propostos pelo tratado para com o corpo estabelecido do direito internacional. O continuum aqui vai desde acordos informais até tratados. Legalidade não é sinônimo de importância; prova disso é que algumas das mais importantes instâncias de cooperação aconteceram sem nenhum acordo escrito, caso do acordo tácito de não agressão entre EUA e URSS durante certo momento da Guerra Fria. Substância, por sua vez, indica o grau de desvio entre o statusquo e o que o tratado em questão demanda das partes, o que em outras palavras pode ser 
entendido como a profundidade real de um tratado ${ }^{2}$. O grau de substância parece ser correlato ao custo de implementação do tratado em questão. O custo de implantação e a distância do status-quo dependerão do ponto de partida inicial de cada um dos atores envolvidos em relação ao conteúdo do tratado. Assim, a assimetria de exigências entre as partes de um tratado é recorrente, embora o tratado seja via de regra exatamente o mesmo para cada um de seus participantes.

Uma ferramenta analítica trazida por Abbott (et al, 2001, p.20) pode ser acrescentada às três apresentadas acima: o conceito de "precisão"3. Precisão pode ser definida pela clareza e grau de elaboração das regras criadas pelo tratado. Esta preocupação é típica do institucionalismo liberal, que crê que a disponibilidade e qualidade de informações entre os agentes têm peso nas ações subseqüentes destes, e que as instituições têm o papel de ajudar neste processo.

Tratados são instrumentos muito maleáveis, podendo se adaptar às diversas facetas das relações entre atores internacionais e às suas recorrentes mudanças. Provas dessa maleabilidade são o uso dos tratados para assuntos tão diferentes como energia nuclear ou direitos das mulheres e a utilização recorrente destes ao longo de toda história das relações internacionais. Mesmo num tema e contexto específico a variedade é grande; tratados de comércio, por exemplo, podem ser feitos tanto para promover como para restringir o comércio (LESTER et al, 2009, p.xiv).

Toda a literatura de Relações Internacionais consultada sobre tratados pressupõe a racionalidade dos atores internacionais e a busca destes por maximizar seus ganhos. Os tratados são também ferramentas usadas racionalmente em busca de ganhos. No

\footnotetext{
${ }^{2}$ É recorrente a argumentação, especialmente baseada nos pressupostos realistas, de que a assinatura de um tratado é somente a ratificação do status-quo, que os atores internacionais só assinam aquilo que de outra maneira já fariam de todo modo, e acrescentam ainda que esta é a principal explicação para o fato de a maioria dos tratados serem cumpridos (RASUTIALA, 2004, p.42; GOSLSMITH et al., 2005, p.83). Para uma contra-argumentação a esta última colocação ver Simmons \& Hopkins (2005) que defendem com dados empíricos que os tratados provocam sim mudanças no comportamento dos atores, e que isso ocorre na maioria das vezes antes de assinar o tratado. O Estado se anteciparia por diversos motivos para se adequar ao tratado e ter certeza de que poderá cumpri-lo, só se comprometendo quando já se modificou, adequando-se ao cumprimento do contrato.

${ }^{3}$ Abbott está discutindo o conceito de legalidade em instituições, que estendemos aos tratados. $\mathrm{O}$ autor traz três fatores: 'precisão', 'delegação' e 'obrigação'. Obrigação e delegação tem definições que se sobrepõem, embora não diretamente, aos conceitos de Raustiala (2004). Visto este paralelismo trouxemos para o texto somente aquele que diferia dos conceitos já citados da última autora.
} 
entanto, variam sobremaneira os motivos e as justificações racionais para se fazer cada um dos tratados. Na superfície, imagina-se que as razões para a existência de um tratado sejam identificáveis pelo conteúdo deste ou pelo efeito que este quer causar no comportamento dos atores. Acreditamos que na maioria dos casos estes são sim os fatores mais relevantes, mas em muitos casos há outros fatores tão ou mais importantes. $\mathrm{O}$ ato político de fazer um tratado está imerso em um mundo complexo e variado, assim é preciso observar de perto cada caso para tentarmos nos aproximar dos motivos para estas ações.

O espetáculo retórico pode ser o que realmente leva um ator a fazer um tratado. Nestes casos temos que nos perguntar quem é a audiência de tal ato, se interna ou externa. Um exemplo seria uma Nação assinar um tratado de direitos humanos não tendo o objetivo real de cumpri-lo, mas sim o de criar sobre si uma aura de cumpridor, e assim, possivelmente, se eximir de críticas por parte da comunidade internacional. De maneira semelhante a mensagem ou a comunicação entre atores internacionais pode ser o objetivo com um tratado (MARTIN, 2005). Por exemplo, num tratado de assistência militar mútua em caso de ataque, o objetivo, além de ter apoio em situação de dificuldade, pode ser o de tentar criar uma détente, e assim de evitar ataques. O tratado neste caso seria uma forma de retórica, uma maneira de transmitir uma mensagem para os outros atores do sistema.

Para alguns tratados com grau de estrutura bastante elevado, ou para aqueles que são base para a criação um regime novo, fazer parte das discussões e negociações (ou da instituição criada por ele) pode ser a melhor maneira de influenciar o resultado final. De modo correlato sair de um tratado com estas características pode levar à perda de voz e do palco, diminuindo assim a possibilidade de influenciar na construção do novo regime ou padrão. A criação da OMC é um bom exemplo. Fazer parte da construção dos seus parâmetros desde o início pode ter sido valioso, em oposição a aderir a ele uma vez que suas regras já estivessem enrijecidas. Diz-se que este foi um dos motivos que levou os Estados Unidos a participarem das discussões e assinarem durante o governo Clinton o tratado criador do Tribunal Penal Internacional. O governo seguinte, de G. W. Bush, discordou das vantagens finais deste e em uma atitude pouco comum "desassinou" o tratado (HELFER, 2005, p.1615). 
Como estão num meio mais amplo de disputa, de competição e cooperação, pode ser que se use um tratado como barganha entre outros fatores. Por exemplo, um país aquiesce em assinar um tratado sobre rios transfronteiriços que pode prejudicá-lo em troca de ganhos econômicos em outra área. Nestes casos, é particularmente nebuloso para o observador externo asseverar a motivação dos atores para suas ações.

Havíamos assinalado que em geral os tratados são entendidos como atos voluntários dos atores, mas isto não significa que eles sejam feitos em ambientes alheios a pressões. Significa sim que, na maioria das vezes, há soberania para pesar as pressões e voluntariamente consentir ou não com elas. A racionalidade por trás de um tratado pode ser simplesmente evitar prováveis conseqüências (mais) danosas. Mesmo tratados considerados injustos podem ser vistos como tendo vantagens que ajudariam a culminar na sua assinatura. $\mathrm{O}$ oneroso tratado de Versalhes, por exemplo, pode ser considerado pela Alemanha melhor do que tratado nenhum, pois reconhece direitos e determina regras de conduta para os ocupantes (GOLDSMITH \& POSNER, 2005, p.90). Podemos assim encontrar elementos de cooperação em tratados feitos sob forte coerção ou pressão, embora esses elementos possam ser consideravelmente fracos.

E não somente o conteúdo do tratado é alvo de ações estratégicas, a entrada, saída, ou somente a ameaça de uma destas ações são comumente usadas estrategicamente (HELFER, 2005; LANTIS, 2009). Exemplo interessante de uso estratégico da saída de tratado foi quando os países da comunidade européia e os EUA retiraram-se do GATT e logo em sequiência assinaram o documento de criação da $\mathrm{OMC}$, fechando a rodada Uruguai no exato momento que seus interesses estavam atendidos. Os outros países, assim, perderam muito com a saída destes grandes jogadores do GATT, o que diminuiu seus benefícios, e tiveram como única alternativa viável entrar também na OMC, aceitando uma série de sujeições desfavoráveis a eles no mesmo pacote (HELFER, 2005, p.1584).

Em alguns casos um tratado pode parecer desnecessário. Consideremos o Tratado de Moscou de 2002 assinado entre Rússia e EUA, em que estes países concordam em diminuir o arsenal de ogivas nucleares. A maioria dos observadores enfatiza que cada um dos atores, independentemente, demonstrava fortes interesses em unilateralmente reduzir o custoso estoque. Porque então fazer um tratado, se ambos os lados estavam 
dispostos a diminuir este arsenal sem ele? Goldsmith e Posner (2005, p.89) argumentam que embora ambos tivessem muito a ganhar agindo sozinhos, há um senso de segurança em saber que a outra parte fará o mesmo, e isso deve acelerar e aprofundar o processo. Em outras palavras, talvez eles não diminuíssem este arsenal tanto e tão rapidamente sem a assinatura do tratado.

Mesmo quando é verdade que podemos identificar os motivos para um tratado pelo seu conteúdo e por suas conseqüências reais e esperadas, ainda estaremos com uma explicação parcial, sendo ainda necessário se perguntar qual o contexto e quais as forças políticas por detrás destas motivações e como elas se desenvolveram até se cristalizar em um tratado.

Se pensarmos em jogos de dois níveis, há diferentes forças políticas internas, muitas vezes contraditórias, que influenciam as ações dos representantes internacionais do Estado (LANTIS, 2009). Essas forças políticas podem ter a preferência ou não por tratados em suas áreas de interesse, e assim fazer pressão para que suas preferências sejam realizadas (KAHLER, 2001, p.283). Pode ser o caso que em um dado assunto o motivo para a ação estatal se concentra na pressão de um lobby interno, ou pode ser que a não ratificação de um tratado por parte do Congresso seja uma mera retaliação política contra o presidente que a defendeu.

Interessante lembrar que o foco nos tratados para estudar cooperação deixa de lado instâncias de cooperação tácita. Às vezes as ligações são tão fortes e dois Estados são tão "amigos" que não são necessários tratados. Por outro lado duas Nações inimigas não têm motivos para cooperar por meio de tratados. Assim os tratados tendem a ocorrer com maior freqüência na gama de casos em que não há nem amizade nem inimizade muito forte, e, claro, em que há ganho com a cooperação (GARRIGA, 2009, p.699). No entanto, como vimos, pode ser que duas Nações amigas ou inimigas façam tratados por outros motivos que não os ganhos de cooperação, como a retórica.

Essa discussão é de grande relevância para este trabalho pois a nossa opção aqui é tentar fazer uma análise do conjunto dos tratados, ao passo que percebemos que, ao menos em relação aos motivos dos tratados, conjuntos gerais são difíceis de serem feitos. Retórica, pressões externas, forças políticas internas, barganhas políticas internacionais, o 
contexto geral, entre outras coisas, isso tudo pode estar ao mesmo tempo motivando um único tratado.

Além da discussão dos motivos para fazer um tratado, há na literatura muitos textos discutindo os motivos para escolher o instrumento 'tratado' ante os outros instrumentos de interação (YOO, 2011; KURTZ \& PEAKE, 2009). Como foi notado, o tratado é um entre vários instrumentos de interação, e a escolha de qual tipo de instrumento usar também é estratégica. Cada instrumento tem vantagens e desvantagens, dependendo dos procedimentos para sua realização. Algumas variações comumente levadas em conta são: grau de transparência requerida; grau de flexibilidade; poder simbólico, retórico e de empenho da reputação que transmitem; e o custo de ratificação (RAUSTIALA, 2004, p.2223). Vale lembrar novamente as contribuições construtivistas que nos mostram que os tratados têm as características que têm, suas vantagens e desvantagens, pois essas características foram construídas ao longo do tempo.

O tratado de Moscou também ilustra o peso do tratado ante outros instrumentos de acordos. A primeira intenção do presidente G. W. Bush era que fosse um acordo de cavalheiros, mas Putin insistiu para que houvesse um instrumento legal na forma de tratado ${ }^{4}$. Os motivos para os congressistas americanos fazerem pressão por esta forma de interação, independente do conteúdo, é ganhar voz e participar das discussões e exercer seu poder nos assuntos de política internacional de seu país. Mas qual seria o motivo para Putin insistir neste tipo de instrumento? A primeira possibilidade seria dar visibilidade retórica para o acordo, mas, no caso, a mais provável deve ser testar o comprometimento dos Estados Unidos com o acordo, para além do poder executivo que é sabidamente transitório (GOLDSMITH \& POSNER, 2005, p.92-94). Pelo fato de ser mais custoso, e de necessitar de um esforço político do executivo americano, Putin pode ficar mais seguro de que os EUA intentam cumprir com o acordado, e do ponto de vista americano a escolha do tratado como instrumento comunica esta intenção.

\footnotetext{
${ }^{4}$ No caso dos Estados Unidos há duas formas diferentes de fazer um acordo legal, o executive agreement $\mathrm{e}$ o tratado (este último também referido como 'Article II Procedure'). Rotular um documento de tratado implica, entre outras coisas, a necessidade e o custo de aprovação do Senado americano por uma maioria de 2/3. O Senado americano desenvolveu uma série de critérios para a escolha da designação do documento (UNITED STATES SENATE, 2001, p.26).
} 
A última das facetas dos tratados que tem grande influência política e que ainda gostaríamos de apontar é o cumprimento ou não dos tratados assinados. Com variações fundadas em diferentes visões teóricas, esta é uma das facetas mais estudadas ${ }^{5}$ pelas Relações Internacionais em relação aos tratados (POLLINS, 1989; GUZMAN, 2002; MITCHELL, 2003; SIMMONS \& HOPKINS, 2005; STEIN, 2005). Quando o tema é estudado empiricamente, a grande maioria dos autores afirma que os tratados em geral são cumpridos, mas a explicação para tal fenômeno é variada. Os motivos que levam um tratado a ser cumprido acompanham em complexidade as discussões sobre os motivos para fazer um tratado, variando de acordo com os inúmeros contextos e forças políticas envolvidos. Por exemplo, é possível que um grupo de tratados (um regime) só tenha grau elevado de cumprimento porque os documentos não tiveram um grau elevado de substância, ou seja, não requeria que os atores se distanciassem muito daquilo que de outro modo já seria feito por eles sem tratado nenhum.

Podemos estruturar as diferentes respostas para os motivos que levam os tratados a serem cumpridos da seguinte forma: a) respostas partindo de dentro do tratado (ele cria seu próprio poder): sanções acordadas, estrutura criada por suas cláusulas; b) respostas partindo de perto dos tratados (o campo social da legalidade cria os meios para seu poder): tratados têm poder simbólico construído socialmente, e eles engendram a penhora da reputação; c) respostas partindo dos interesses dos atores para fazer tratados: tratados só são cumpridos quando há ganhos comuns como benefícios de cooperação e coordenação, benefícios de troca de informações, transparência e previsibilidade (uma vez que os motivos desapareçam os tratados deixarão de ser cumpridos); d) respostas partindo de longe do tratado: exercício do poder (possivelmente da Nação hegemônica) e a pressão fora do âmbito do tratado fazem com que eles sejam cumpridos.

\subsection{A opção metodológica deste trabalho}

O objetivo deste trabalho, como vimos na Introdução, é construir ferramentas para manipular um banco de dados de tratados na esperança de retirar deste informações

\footnotetext{
${ }^{5}$ Uma bibliografia comentada sobre o tema pode ser encontrada no texto de William Bradford (2004), International Legal Compliance: Surveying the Discipline.
} 
relevantes para o estudo das Relações Internacionais. O resultado final, materializado nas ferramentas, é o ponto de chegada de uma série de encadeamentos de fatores em que um possível erro no primeiro passo poderá ser levado adiante aos próximos, enfraquecendo o resultado final. Se o analista não estiver consciente desses fatores pode ser enganado pela ferramenta ao invés de ser elucidado por ela. Os principais encadeamentos são ${ }^{6}$ :

A) Entre o mundo da política internacional e os tratados, isto é, se os tratados podem ser uma expressão de algo em geral das relações internacionais. Como vimos na sessão anterior, o que são os tratados, o que significam, quais os motivos para fazê-los, tudo isso é amplamente debatido. É importante notar que por opção deste projeto escolhemos fazer uma análise do conjunto dos tratados e não de alguns tratados em particular, por isso não basta que cada tratado possa ser estudado em particular, é necessário, para manter o poder deste projeto, que o estudo do conjunto deles seja também possível e relevante.

B) Entre estas expressões e os dados. Assumindo que os tratados são uma expressão de algo das relações internacionais e que essa expressão pode ser vista de um ponto de vista distante e geral, devemos nos preocupar se estes dados estão completos, se são homogêneos, se são representativos, etc., de maneira que os dados continuem representando o que teoricamente se acredita que representam. É preciso, portanto, avaliar a qualidade dos dados utilizados, pesando-a pragmaticamente com as necessidades da análise em questão.

C) Se os dados recolhidos e transformados em um banco de dados para a ferramenta mantêm a ligação anterior. Dadas as características dos dados e da ferramenta escolhida, os dados sofrem inevitavelmente transformações (seleção de certas informações, seleção das variáveis, uso do processo de compilação, organização dos dados usando certos critérios objetivos e subjetivos). Novamente é preciso ficar atento para saber se estas transformações modificaram substancialmente os dados e se houve prejuízo para alguma de suas qualidades. Em outras palavras, é necessário estar atento para a manipulação e as transformações que são feitas nos dados.

\footnotetext{
${ }^{6}$ Esses encadeamentos poderiam ser também divididos de outra maneira, entre aqueles que são escolhas metodológicas (escolha de usar tratados, fazê-lo quantitativamente, usar representações visuais, e os problemas envolvidos com esta escolha), e os referentes à sua execução (que dados usar, como usá-los e seus problemas; que representação usar e seus problemas).
} 
D) Se as ferramentas escolhidas representam os dados de forma correta (as inevitáveis distorções para fazer este passo devem estar descritas, e se possível devem ser trabalhadas e minimizadas) e se uma ferramenta supre os defeitos da outra.

E) Finalmente, se o usuário da ferramenta consegue fazer uma análise correta do que as ferramentas representam. Isso dependerá do seu conhecimento prévio do tema buscado, da sua desenvoltura em aprender a usar as ferramentas, e da sua capacidade de perceber o conjunto de problemas deste longo encadeamento e pesar criticamente as informações que vê.

Cada um destes encadeamentos é tratado em determinada parte deste trabalho ${ }^{7}$; nesta sessão gostaríamos somente de continuar a discussão do primeiro deles. Como vimos na primeira sessão deste capítulo, o significado dos tratados e quais de suas características são relevantes variam de acordo com o olhar teórico das Relações Internacionais adotado. Agora gostaríamos somente de acrescentar uma discussão sobre o olhar metodológico especifico escolhido para ser base para este projeto: uma análise quantitativa e distante dos tratados, isto é, o ponto (A) acima.

Gostaríamos nesta sessão apresentar a escolha metodológica deste trabalho, isto é, criar ferramentas para estudar os padrões gerais dos tratados, e algumas de suas conseqüências epistemológicas. Esperamos deixar claro que há limitações partindo destas escolhas para o bom uso das ferramentas propostas. Contrastando com a sessão anterior, onde apresentamos uma ampla gama de variações nas qualificações e nos interesses das Relações Internacionais pelos tratados, aqui focaremos em deixar evidente que nem todos aqueles fatores são refletidos pela maneira escolhida de utilizar os dados, e ainda que a qualidade daqueles que são é variada.

Quando pensamos em tratados o estudo dos padrões gerais não é o mais corrente na disciplina de Relações Internacionais. Mais freqüente é estudar as implicações de um único tratado, ou fazer uma lista de tratados feitos num dado período de governo de um dado país, encaixando estes como um dos fatores da política externa em questão. Outros ainda estudam um tema, por exemplo comércio internacional, e analisam os tratados

\footnotetext{
${ }^{7}$ Descreveremos os dados (B) e os processos de transformações destes (C) no Capítulo 3. Descreveremos as ferramentas utilizadas e suas conseqüências (D) no Capítulo 2. Os problemas de interpretação final pelo usuário (E) é tratado no presente capítulo e também através de exemplos de uso no Capítulo 4.
} 
referentes a esse tema vendo seus conteúdos e suas implicações políticas. Vale mencionar ainda que é bastante desenvolvido o estudo dos tratados de um ponto de vista do direito internacional, analisando por exemplo o desenvolvimento de cláusulas de resolução de conflito, da codificação do direito internacional, ou da prática de sucessão aos tratados quando um Estado por alguma razão se transforma em outro.

Há, no entanto, alguns trabalhos em Relações Internacionais que adotam um ponto de vista mais generalista ou mesmo quantitativo em relação ao estudo dos tratados. Um dos primeiros trabalhos com grandes quantidades de tratados foi feito no início da década de 1960 compilando os tratados publicados pela ONU com ajuda de cartão perfurado (ROHN, 1968). Isto deu início a levantamentos do que ficou conhecido como “UNTS Gap" ou a diferença entre a lista nacional dos tratados celebrados por uma nação e a lista dos tratados registrados na ONU. Há levantamentos dos tratados feitos por alguns países, como União Soviética (TRISKA, 1964), China (SCOTT, 1973; SHINOBU, 1987), Japão (ADAMS, 1972), Canadá (ROHN, 1966), e Estados Unidos (VOIGT, 2011).

Outros estudos fazem levantamentos de tratados com um tema referente em comum, como, por exemplo, compêndio e análise dos tratados sobre rios transfronteiriços (ZAWAHRI, 2008) ou das características dos tratados multilaterais sobre o meio ambiente (MITCHELL, 2003). Neste âmbito os estudos que têm por objeto os tratados econômicos, dada sua importância imediata, são os mais freqüentes e variados. Há desde estudos sobre o fenômeno de grande aumento do número de tratados preferenciais de comércio na década de 1860 (LAZER, 1999), passando pelo estudo da correlação estatística entre o número de tratados preferenciais de comércio com o fluxo de investimento direto (BÜTHE et al., 2008), até estudos de tratados de dupla taxação de importações (BARTHEL et al., 2010). A UNCTAD promoveu uma revisão geral dos tratados de investimento externo para a década de 1990, concluindo que ganharam cada vez mais importância os tratados bilaterais (UNCTAD, 2000). Este estudo incluiu um compêndio de todos os tratados feitos durante o período (década em que o número de tratados deste tipo quintuplicou). Já o livro de Simon Lester (LESTER, et al. 2009) coloca a década de 1990 em perspectiva acompanhando as trajetórias de usos de tratados econômicos bilaterais e multilaterais, mostrando como foram variados os objetivos de ambos ao longo do século XX (desde aumentar ganhos 
domésticos, promover política exterior e desenvolver alianças econômicas, políticas, sociais e culturais).

Robert A. Denemark e Matthew J. Hoffmann em anos recentes fizeram vários estudos quantitativos usando para isso uma base de dados de tratados multilaterais, com mais de seis mil tratados ao longo dos últimos quatrocentos anos (DENEMARK \& HOFFMANN, 2006, 2007, 2008[a], 2008[b]). A partir desses dados os trabalhos respondiam a questões distintas sobre a dinâmica de interação cooperativa entre as nações, controlando para diferentes variáveis, tais como presença ou não de hegemonia ou liderança, aumento do comércio internacional, ou o número de Estados no sistema. Em um dos estudos $(2008[\mathrm{~b}])$ os autores usaram uma representação em rede (network analysis) para estudar a centralidade dos atores no sistema em diversas épocas. A representação em rede pode ser considerada uma visualização de dados, o que a aproxima de certa forma do nosso projeto. Essa base de dados criada por Denemark e Hoffmann foi aproveitada por outros autores que fizeram um compêndio dos locais de assinatura destes tratados multilaterais para com isso discutir o que foi chamado de 'geografia diplomática' (WUSTEN, et al, 2011).

Finalmente, há alguns estudos que se preocupam em inferir empiricamente, compilando grande quantidade de tratados, se estes têm efeito sobre os atores, em outras palavras, se são obedecidos pelas obrigações legais que impõem, ou se são mera ratificação do status-quo anterior (STEIN, 2005; SIMMONS et al, 2005).

Este trabalho toma um caminho semelhante a esses estudos, na medida em que faz um levantamento de uma grande quantidade de tratados e tenta, por meio da construção de ferramentas específicas, permitir a manipulação e representação destes dados. Sugerimos que podem existir padrões escondidos nestes dados que podem ser de interesse para vários estudos das Relações Internacionais. A opção foi então a de não focar em nenhum tratado em específico, mas sim a de olhar para o conjunto dos tratados como um todo e estudar esse conjunto. Para que isso fosse feito foi necessário escolher as informações que associaremos a cada um dos tratados e que utilizaremos como variáveis nas análises. De acordo com o que nos fornecem os dados compilados pela ONU, dadas as possibilidades de representação das ferramentas, e dado o que entendemos ser de interesse para as Relações Internacionais, 
decidimos recolher grosseiramente as seguintes informações: datas, participantes, lateralidade, e o assunto do tratado. Essas características serão usadas como variáveis para produzir as representações, que por sua vez deverão servir de base para analisar a natureza dos dados e seu significado.

Em forte contraste com a primeira parte deste capítulo, na qual vimos como podem variar os sentidos, os motivos, as conseqüências de cada tratado, a opção escolhida leva a retirá-los de seu contexto político e histórico. Neste sentido esta opção metodológica conscientemente promove uma distorção reducionista tendo em vista objetivos analíticos pragmáticos (WOODS \& ROSALES, 2010). Utilizamos a contagem de eventos como base para a análise (SCHRODT, 1993).

Aqui cabe uma observação importante: os dados foram sim retirados de seu contexto, mas não se espera o mesmo de sua análise. Entendemos que as ferramentas podem sim ajudar o analista a descobrir novas informações, a fazer novas perguntas ou a buscar suas respostas, mas isso normalmente só pode ser feito levando em conta o contexto histórico e político envolvido. É tarefa do analista juntar novamente estas pontas e utilizar seu conhecimento prévio para moldar seu entendimento das representações destes dados. Alguém que ignora toda a história das relações políticas de um ator internacional ao se deparar com as ferramentas aqui propostas terá um entendimento muito distinto do que terá um especialista no mesmo tema - e é especialmente para este último que a ferramenta é pensada.

Além da escolha da metodologia, a execução desta também pode ser problematizada, visto que o resultado final depende muito dos passos que levam dos dados até sua representação. Os dados podem ser parciais, ou seja, não representar verdadeiramente o que se espera deles, podem ser tendenciosos e viciados de alguma forma, a compilação destes pode conter problemas de método, levando a resultados errôneos, a ferramenta pode distorcer os dados de uma maneira que sua interpretação fique prejudicada (ROTHMAN, 2007). Por exemplo, se um país não faz parte da ONU, e portanto não é obrigado pela sua Carta, só terá no banco de dados utilizado os tratados que celebrou com os seus pares que são membros registrados, isto é, ocorrerá uma distorção na 
representação final em relação às verdadeiras relações políticas. A discussão pormenorizada sobre os dados está no Capítulo 3.

A ferramenta, por sua vez, também transformará os dados em representações. É preciso saber exatamente como as ferramentas operam com os dados e quais serão as consequiências dessas operações. As modificações podem afetar a percepção final do observador sobre o conjunto dos dados representados, levando a perda de consistência. A descrição das ferramentas é feita no Capítulo 2.

Assim já podemos ter um entendimento grosseiro dos problemas que se acumulam para a utilização das ferramentas propostas. As diferentes interpretações possíveis para estes eventos individualmente e especialmente em conjunto; a qualidade, representatividade, homogeneidade dos dados e outras características destes; a ferramenta de representação visual, que também modifica os dados; e finalmente o olhar do observador final, seu conhecimento prévio, sua familiaridade com o uso desse tipo de ferramenta, tudo isso está no meio do caminho da ligação entre o mundo da política e a análise de uma representação visual através dos dados e das ferramentas escolhidas. As vicissitudes de cada um deles determinarão os limites de uso das ferramentas para determinados fins, e por isso esta análise crítica de todos estes passos se torna muito importante. 


\section{CAPÍTULO 2. Descrição das Ferramentas}

\subsection{Introdução}

Do ponto de vista cognitivo, muitos autores enfatizam as vantagens que uma representação visual pode acarretar. Argumentam que os seres humanos desenvolveram ao longo de sua longa história evolutiva aguçada capacidade visual de percepção, e assim, heuristicamente, as ferramentas visuais adquiriram amplo uso. Aliada a tecnologias e artefatos externos, parte da carga cognitiva foi retirada do observador (GREEN, 2008; DROR \& HARNAD, 2009), facilitando tarefas e por vezes as tornando executáveis pela primeira vez (DROR, 2007). Argumenta-se ainda que algumas representações visuais podem ajudar na processabilidade ao limitar a abstração (STENNING \& OBERLANDER, 1995), ou ainda guiar o raciocínio ao restringir as inferências possíveis (PRICE, 2002). Podem ainda, ao reduzir a complexidade, ajudar grupos e indivíduos no processo de pensamento em situações complexas demais para serem encaradas exclusivamente pela cognição interna (HOFFMANN, 2007; EBERT et al, 2009).

Devido às vantagens cognitivas mencionadas, em certos casos as representações visuais são ferramentas de geração de conhecimento. Elas fazem isso de diversas maneiras. Primeiro, ao externalizar uma representação há a possibilidade de explorar os dados de uma maneira distinta, viabilizando a descoberta de novos fatores, relações possíveis, padrões e interações entre variáveis. (FRIENDLY, 2009; GREEN, 2008; HOFFMANN, 2007). O observador pode ainda ser levado a ter insights, ou a criativamente formular novas hipóteses, novas perguntas, ou a melhorar velhas perguntas (WIJK, 2005).

Representações visuais têm ainda amplo uso na comunicação de conhecimento, ou, do ponto de vista do receptor, na aquisição de conhecimento já construído. Há tipos de saberes cuja comunicação é muito mais fácil ou simples por meio de representações visuais se comparado a descrições usando linguagem comum ou matemática (HALLISEY, 2005); exemplos clássicos são mapas para transmitir grande quantidade de informação espacial. Desta forma, representações visuais se aproximam também de uma melhor didática, servindo como facilitadores para transmissão de conhecimento (BURKHARD, 2004; GILBERT \& REINER \& NAKHLEH, 2008). 
No entanto, as representações visuais não se encontram fora do mundo social em que são produzidas e utilizadas. Isso significa que relações sociais e relações de poder devem sempre ser levadas em conta quando este tema é tratado (PENNA-FORTE, 2006, pp.105-115; LATOUR, 1986). Por exemplo, muitas vezes, na comunicação, usa-se uma representação visual pelo seu valor de convencimento, ou pelo valor simbólico que carrega, em uma clara opção retórica (WIJK, 2005; HALLISEY, 2005 pp.358). E há casos em que intencionalmente se tenta enganar o interlocutor através do uso destas ferramentas. (TUFTE, 1990, 1997, 2001; MONMONIER, 1996). Nesse caso, as mesmas vantagens cognitivas das representações visuais que fortalecem seu uso em diferentes tipos de comunicação são usadas contra uma boa comunicação. A cultura e o poder estão na base de qualquer construção ou uso de representações, inclusas as visuais. Fugir totalmente disso parece impossível, mas grande parte do perigo pode ser evitada explicitando essas relações e tomando consciência delas (HOFFMANN, 2007 pp. 21).

Além das vantagens cognitivas, as visualizações de informação trazem vantagens de ordem prática ao permitir a manipulação de conjuntos de dados de forma produtiva que sem estas ferramentas não poderiam ser analisados. Nas ciências humanas o grande crescimento da quantidade de informações, facilitado pelos desenvolvimentos tecnológicos recentes e como resultado de uma mudança cultural, impõe desafios crescentes de análise, especialmente pela quantidade, pela multidimensionalidade e pela dinamicidade. As visualizações de informação (ou de dados) vêm justamente neste propósito se aproveitando das capacidades visuais e cognitivas dos seres humanos e das capacidades de modelagem das novas tecnologias, em especial de computação, para ajudar nesta tarefa (GAHEGAN, 2007; STONE, 2009; LAZER, 2009; ZINOVYEV, 2010). As técnicas de representação visual de dados têm vantagens de acordo com as informações a serem representados, mas vale lembrar que há também desvantagens associadas (BRESCIANI \& EPPLER, 2008). O clássico exemplo desta balança entre vantagens e desvantagens se vê na comparação entre gráficos e tabelas. $O$ primeiro permite a comparação rápida e verificação de tendências com muita facilidade; o segundo, no entanto, retém uma precisão dos dados consideravelmente maior. A escolha do método para lidar com um grupo de dados deve considerar os objetivos desta manipulação. Embora um 
simples gráfico de barras possa ser considerado uma visualização de informação, convencionou-se usar o termo para métodos alternativos de representação especializados em tentar resolver problemas onde os métodos tradicionais encontram dificuldades.

Dentro da disciplina de Relações Internacionais não é diferente, temos uma grande geração de informações que pode se beneficiar muito destes métodos (GLEDITSCH et al, 2005). Exemplos bastante interessantes já existem, como o uso de técnicas de análise de rede (BRANDES et al, 1999; MAOZ at al, 2003; BRANDES, 2009; HAFNERBURTON et al, 2009; FISHER, 2010), de contagem de palavras de discursos de política externa, ou mapas temáticos.

\subsection{Descrição das ferramentas}

\subsubsection{Ferramenta de representação radial}

Entre as diferentes representações possíveis para os dados a escolha do gráfico de dependência radial foi feita com base especialmente nas características dos dados que gostaríamos de ter representados. Isto não equivale a dizer que outras possibilidades não possam ser utilizadas buscando enfatizar outras características destes mesmos dados.

De forma simplificada no nosso caso o gráfico de dependência radial representa os atores internacionais dispostos como sessões de um anel e traça linhas de diferentes cores e espessuras para representar os tratados entre estes atores. Se por exemplo Brasil e Argentina têm um tratado registrado, uma linha se estenderá ligando um até o outro. Sublinhamos o aspecto intuitivo da representação, ao mostrar uma "conexão" entre atores internacionais, que os obriga diante do direito internacional, através de uma linha entre estes dois atores.

O gráfico de dependência radial é uma versão com características específicas de uma representação de rede (network visualization, sociograma, entre outros nomes). As diferenças mais marcantes são a possibilidade de organizar os dados através de hierarquias e o fato de ser conferida relevância maior às ligações que aos atores (ou, no jargão dos estudos de rede, maior ênfase é dada às arestas do que aos nós da rede). Ao fazer esta escolha ganhamos de um lado mas perdemos em outro. O ganho é claramente dar importância maior aos tratados (as linhas, ou arestas) do que aos atores, ao situar os últimos 
fixamente o mais longe possível de todos os outros (um círculo), dando mais espaço para as linhas no centro. A perda fica na impossibilidade de movimentação dos atores, que poderia ser utilizada como fator de análise (isto é feito em análises de rede: de acordo com um peso dado para cada ligação os atores se aproximam ou se afastam criando grupos identificáveis). A maioria dos trabalhos que se utilizam da técnica de análise de rede (network analysis) leva em conta justamente esta variável. O problema prático implícito é a dificuldade de representar grandes bancos de dados, com grandes quantidades de atores e de ligações entre eles ${ }^{8}$.

O banco de dados pode ser manipulado pela tela inicial da aplicação. É possível escolher A) um ou mais atores para serem representados; B) um ou mais assuntos relativos a estes tratados; C) o recorte temporal, isto é, dar a data inicial e final da seleção. Datas de assinatura, ratificação, entrada em vigor e término estão disponíveis para serem manipuladas. É possível utilizar mais de um tipo de data ao mesmo tempo; por exemplo, o usuário pode querer ver os tratados assinados $e$ que entraram em vigor num período estipulado, ou os tratados que foram assinados ou que entraram em vigor num certo período. Outro exemplo seria incluir em uma dada seleção todos os tratados que foram extintos num dado período, pois por definição, se no final da seleção temporal o tratado não mais estiver em vigor, ele não será representado. D) É possível escolher se são incluídos ou não os tratados que caem dentro do critério de publicação parcial; como esses tratados são freqüentemente mais técnicos e de maneira geral menos importantes (como será visto na sessão 3.2.8.), pode ser do interesse do usuário não utilizar estes dados na representação visual.

Nota-se ainda que existem duas barras de visualizações, sendo possível escolher em qual delas se quer fazer a representação. Isso permite fazer duas pesquisas com critérios distintos e ajuda a fazer comparações entre duas representações.

\footnotetext{
${ }^{8}$ Há uma série de trabalhos que focam justamente em tentar minimizar ou contornar estas dificuldades. $\mathrm{O}$ nosso trabalho também não está livre dessas dificuldades e a opção de fixar os atores o mais distante possível uns dos outros é uma tentativa de lidar com isso, em detrimento de usar a posição dos atores para representar alguma variável.
} 
Figura 2.1. Tela inicial da visualização radial, com os controles do banco de dados.

Filtros e buscas

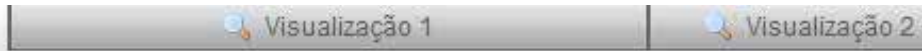

- Visualização $1 \bigcirc$ Visualização $2 \square$ Incluir Publicações Parciaís

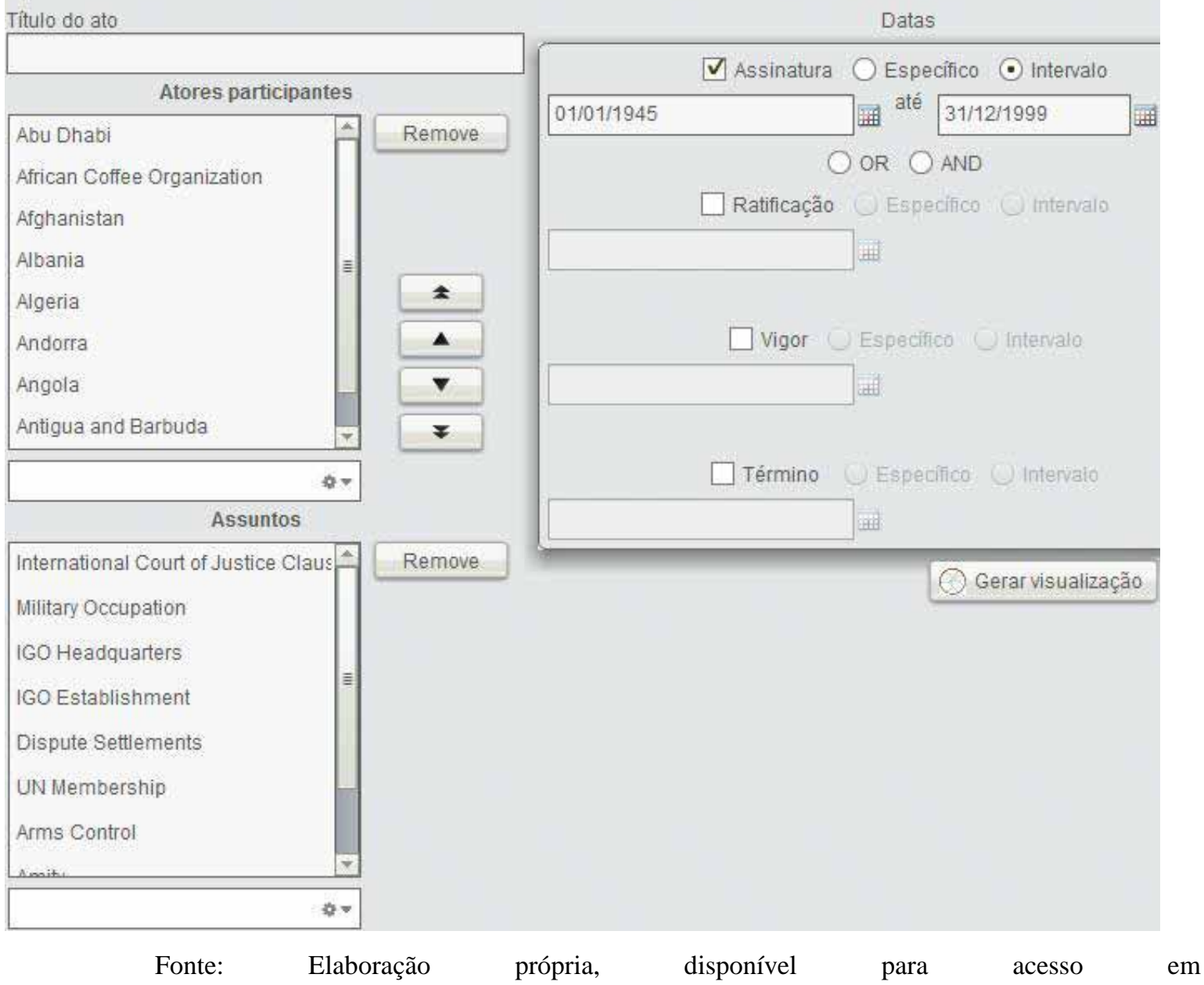

http://www.treatypatterns.com:40760/view/ .

Ao interagir com o banco de dados, escolhendo atores, assuntos, datas e clicando em 'gerar visualização', o programa acessa o banco de dados com as variáveis pedidas pelo usuário e retorna as informações necessárias para que seja assim construída uma representação radial em Flash. Chamaremos de 'seleção' os dados que foram escolhidos por estes métodos de interação como banco de dados. A figura a seguir mostra 
um exemplo de representação construído pela ferramenta, tendo por seleção todos os tratados bilaterais em que o Brasil é parte.

Figura 2.2. Representação de todos os tratados bilaterais do Brasil, 1900-2000.

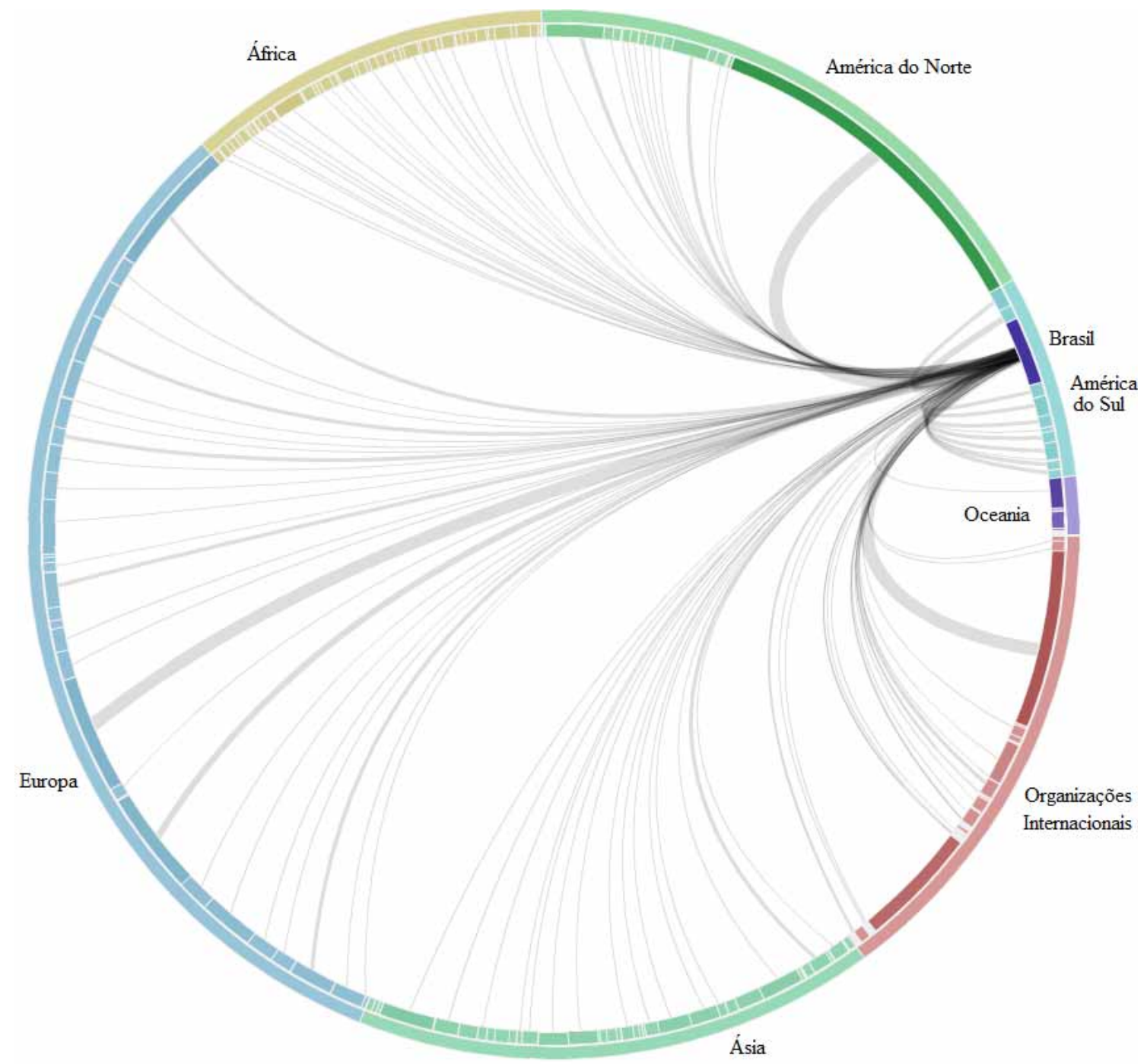

Fonte: Elaboração própria com base nos dados do World Treaty Index.

Nota: Os nomes dos continentes foram posteriormente adicionados à imagem, estes não aparecem deste modo na ferramenta, sendo preciso "passar" o mouse sobre as sessões para ver seus nomes.

A Figura 2.2. é composta por dois anéis concêntricos. $\mathrm{O}$ anel interno é dividido em várias sessões, cada uma delas representando um ator internacional distinto. No caso 
acima o Brasil foi o ator selecionado, e os tratados de que faz parte são representados pelas linhas que partem da, ou chegam à, sessão do anel que o representa. $O$ anel externo representa o superior hierárquico dos atores do anel interno, o que chamamos de conglomerados. Os conglomerados da imagem acima são os continentes, cada sessão do anel externo representa um deles com uma cor distinta. Assim, todos os países africanos estão representados em amarelo por sessões do anel interno logo abaixo de uma grande sessão do anel externo que representa a África. O tamanho de cada sessão é determinado pelo programa de acordo com a quantidade de tratados que cada ator tem no banco de dados, assim atores com mais tratados registrados serão representados por uma sessão de anel proporcionalmente maior.

Os tratados, como dissemos, são representados pelas linhas que ligam as sessões do anel interno. A cor e a espessura das linhas são usadas para representar respectivamente o assunto associado ao tratado e a quantidade de tratados entre os atores. De acordo com a quantidade de tratados da seleção o programa decidirá mostrar ou não os tratados diferenciando os assuntos relacionados, isto é, usando diferentes cores para assuntos diferentes ou somente a cinza. Na Figura 2.2. acima não há diferenças entre os assuntos dos tratados, que se juntam em uma única linha cinza. A linha terá uma espessura de acordo com a quantidade de tratados entre as partes; no caso supracitado as três linhas visivelmente com maior espessura são aquelas que ligam o Brasil aos Estados Unidos, à Alemanha Ocidental e ao BIRD.

É possível, no entanto, usar diferentes cores para representar as diferenças nos assuntos relativos aos tratados. A figura a seguir exemplifica isso. 
Figura. 2.3. Todos os tratados bilaterais categorizado nos assuntos 'Raw Materials Trade' e 'General Trade', 1900-2000.

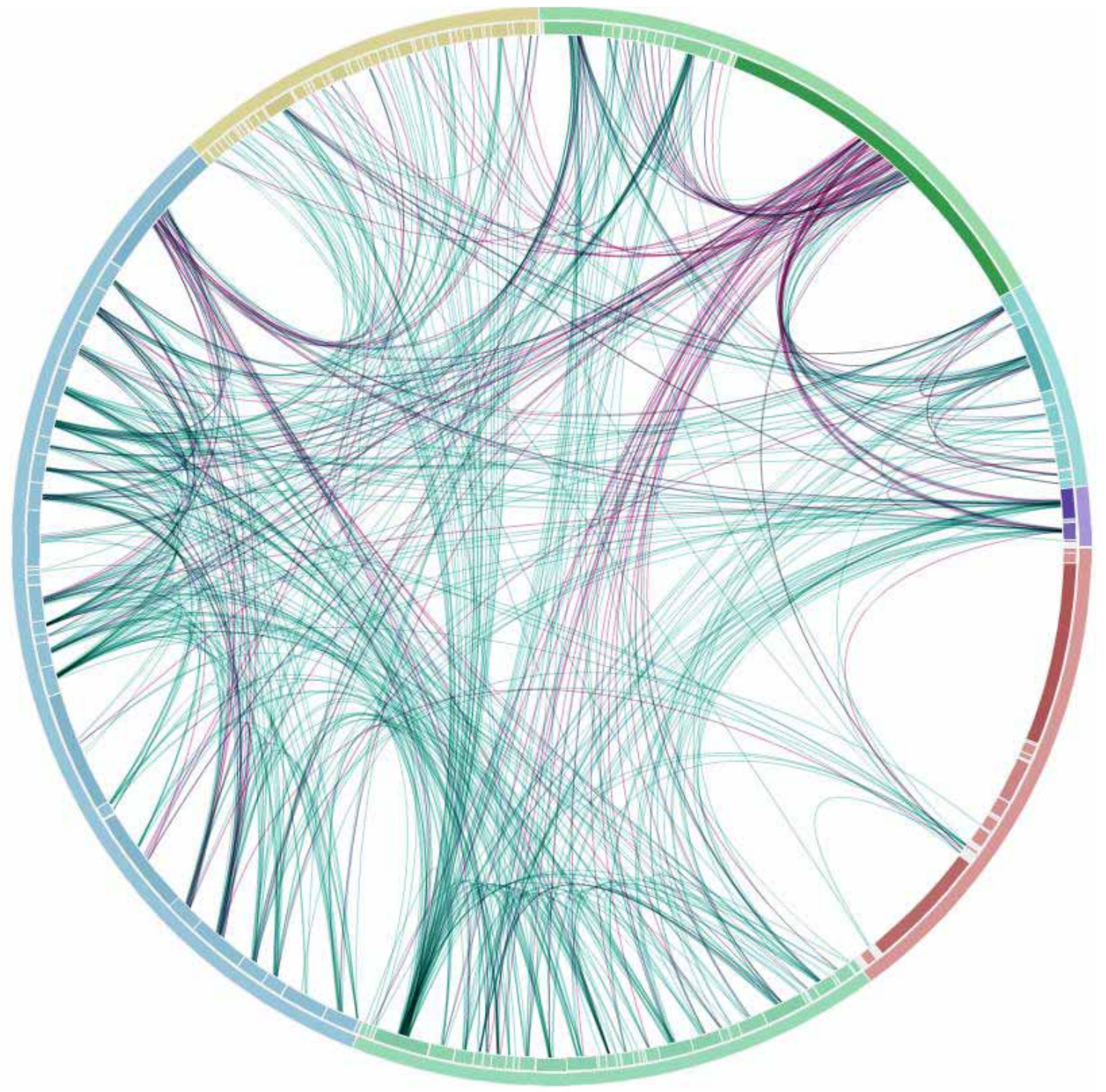

Fonte: Elaboração própria com base nos dados do World Treaty Index.

Nota: Em azul os tratados sob a categoria 'General Trade' e em roxo 'Raw Materials Trade'.

Olhando para a Figura 2.3. pode-se comparar os padrões entre os conjuntos de tratados categorizados em dois assuntos distintos, e perceber por exemplo, que há uma concentração de tratados categorizados como 'Raw Material Trade' no ator EUA (a maior sessão em verde escuro no canto superior direito). Estes padrões podem ser significativos para analistas interessados nos tratados de comércio, que olhando para esta visualização, e 
percebendo estes padrões, podem questionar, e posteriormente investigar, os motivos destas constantes.

Para além das manipulações com os o banco de dados, a ferramenta permite uma série de interações do usuário diretamente com a visualização criada a partir da seleção: A) Ao passar o mouse por sobre cada uma das sessões dos anéis algumas informações sobre elas aparecem: nome da sessão, superior hierárquico e quantidades de tratados na seleção (veja Figura 2.4.A. abaixo); B) Ao passar o mouse sobre uma linha uma caixa de informações mostra a quantidade de tratados, e o assunto (veja Figura 2.4.B. abaixo); C) Ao clicar em uma sessão um sub-recorte é feito na seleção, mostrando somente os tratados da sessão clicada que fazem parte da seleção escolhida anteriormente. Isso pode ser feito tanto com atores do anel interno quanto com os continentes do anel externo; D) Ao clicar em uma linha uma caixa de informações mostra quais são os tratados que a linha representa. A partir daí é possível clicar em cada um dos tratados e ver todas as informações sobre eles (veja a Figura 2.5.).

Figura 2.4. Interações com a visualização.

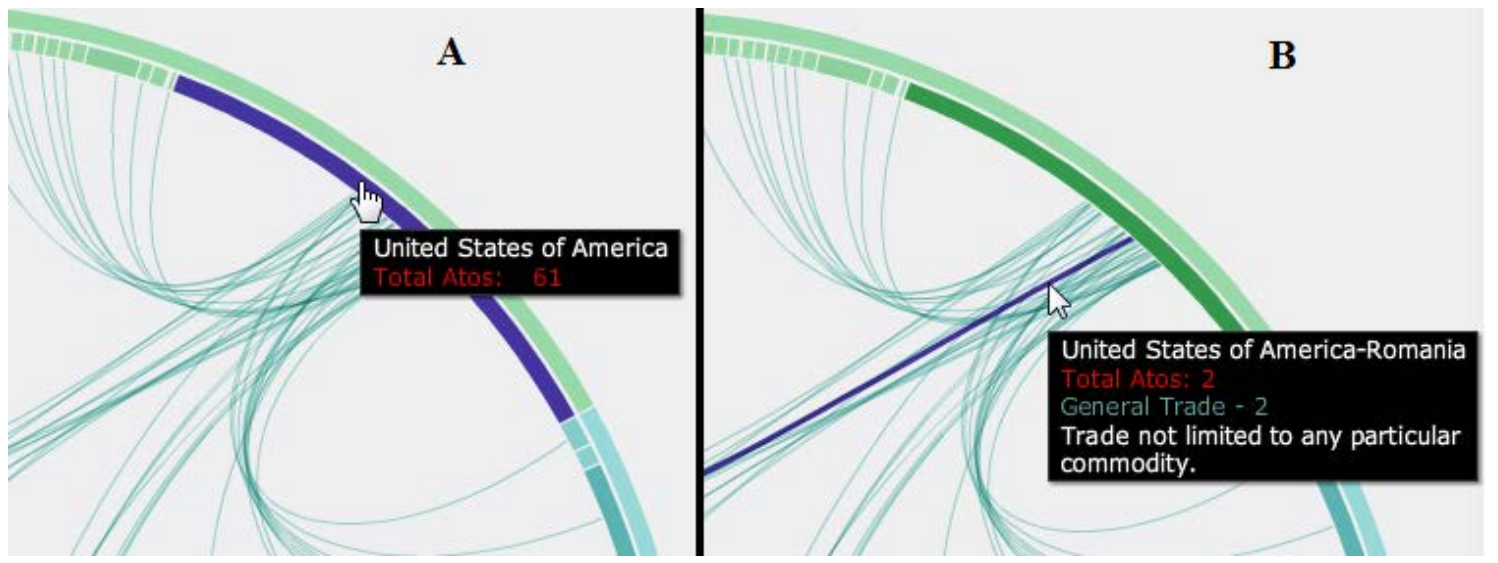

Nota: Figura A: mouse sobre a sessão EUA; Figura B: Mouse sobre a linha entre EUA e Romênia, representando tratados de comércio entre eles. 
Figura 2.5. Caixa de informações sobre cada tratado.

\begin{tabular}{|c|c|c|c|}
\hline \multicolumn{3}{|c|}{ Informações Adicionais } & $x$ \\
\hline \multicolumn{4}{|l|}{ Tratados } \\
\hline \multicolumn{4}{|c|}{ TRADE RELATED MATTERS DURING TRANSITIONAL PERIOD FOLLOWING INDE } \\
\hline \multicolumn{4}{|c|}{ TRANSFER OF AGRICULTURAL COMMODHES } \\
\hline \multicolumn{4}{|c|}{ TRANSFER OF AGRICULTURAL COMMODITIES. } \\
\hline \multicolumn{4}{|l|}{ TRADE } \\
\hline \multicolumn{4}{|c|}{ TRANSFER OF AGRICULTURAL COMMODITIES. } \\
\hline Data de assinatura: & $09 / 11 / 1972$ & Publicação Parcial: false & \\
\hline Data de ratificação: & $09 / 11 / 1972$ & UNTS-WTI & \\
\hline Data de vigor: & $09 / 11 / 1972$ & Volume: & \\
\hline \multicolumn{2}{|l|}{ Data de término: } & Página: & \\
\hline Local de assinatura: & NULL & Código UN Database: NULL & \\
\hline \multirow{2}{*}{ Assuntos: } & $\begin{array}{l}\text { General Trade: Trade not limited } \\
\text { to any particular }\end{array}$ & Link UN Database: NULL & \\
\hline & commodity. & \multirow{2}{*}{$\begin{array}{l}\text { Tópico WTI } \\
\text { Database: }\end{array}$} & \\
\hline Lateralidade: & bilateral & & \\
\hline Membros: & $\begin{array}{l}\text { Philippines } \\
\text { United States of America }\end{array}$ & Notas: & \\
\hline
\end{tabular}

Fonte: Elaboração própria.

A ferramenta apresenta ainda as seguintes possibilidades: exportar a seleção de dados e gravá-la no próprio computador; gravar a representação em exibição como imagem no próprio computador; incluir ou não as Organizações Internacionais na representação.

Aplicamos na ferramenta uma técnica de aglomeração das linhas e permitimos sua manipulação pelo usuário na visualização final. Esta técnica, chamada de edge bundle technic (HOLTEN, 2006), visa ajudar na organização das linhas dentro do círculo, dando maior clareza aos dados e fazendo a estrutura subjacente se tornar mais explicita. Em poucas palavras, ela modifica o caminho que as linhas fariam entre os dois atores, que de outro modo seria uma linha reta entre estes dois pontos. O novo caminho seguido para ligar estes dois pontos é determinado pela hierarquia de cada ator ou sessão do anel. Todos os 
tratados, representados pelas linhas, feitos pelos países de um continente se curvarão em direção a um ponto comum, depois seguirão para seu destino final passando por ponto semelhante do continente do ator de destino. Essa técnica facilita o entendimento da distribuição dos dados. A Figura 2.6. a seguir mostra o processo de uso de diferentes fatores de agregação utilizados. O fator de aglomeração pode ser variado de acordo com a vontade do usuário; uma barra no canto superior direito da visualização permite esta interação.

Figura 2.6. Exemplo de agregação das linhas por fator hierárquico.
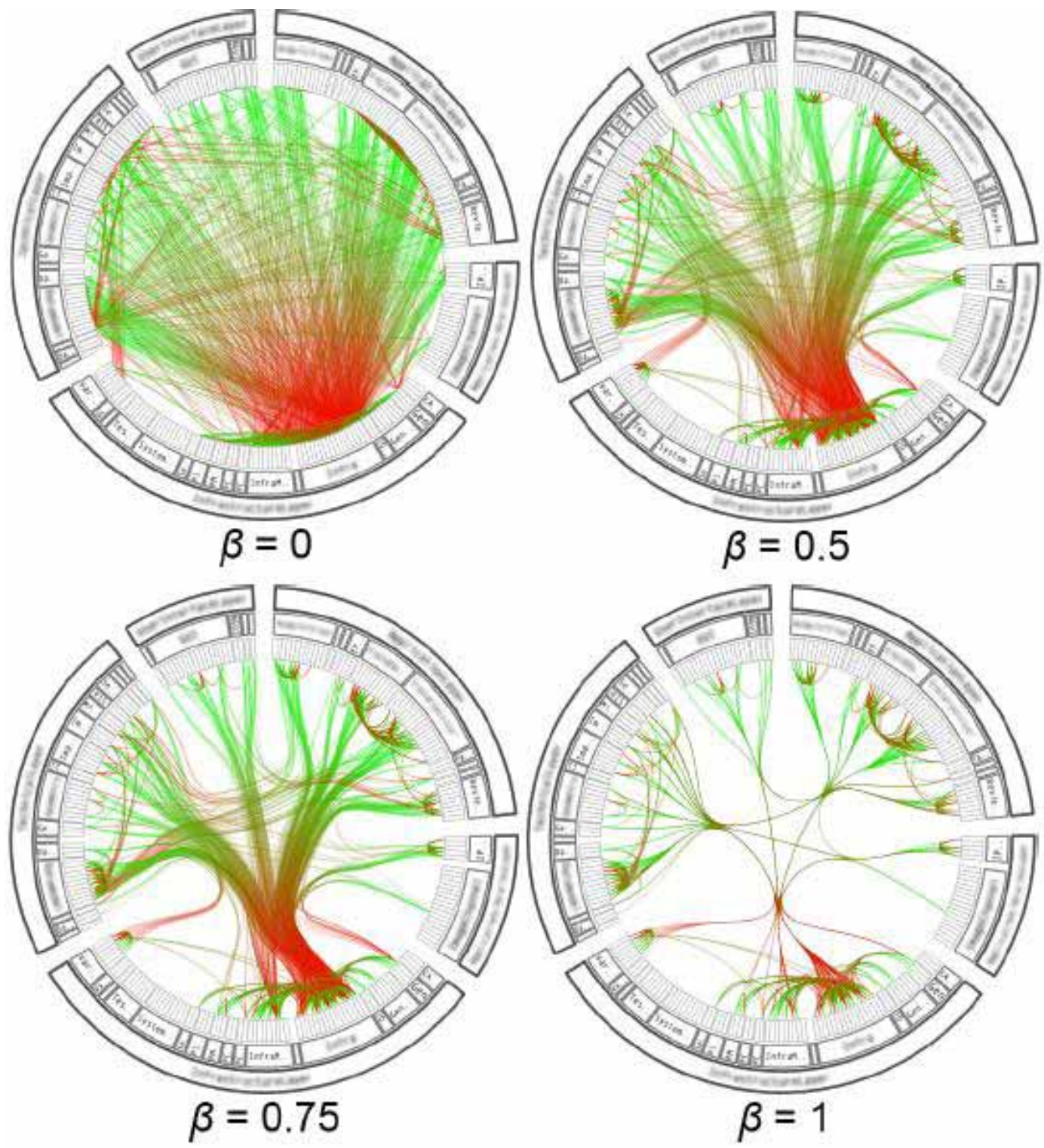

Fonte: (HOLTEN, 2006). 


\subsubsection{Ferramenta de geração de relatório, gráfico temporal e mapa}

A segunda ferramenta proposta foi feita com o objetivo de suprir algumas carências que a primeira apresentava. Duas dimensões poderiam ser melhor representadas usando ferramentas simples e já bem conhecidas: um mapa e um gráfico de barras. O mapa representa melhor a distribuição espacial dos tratados entre os países, e o gráfico de barras pode ser usado para explicitar os padrões de distribuição dos tratados ao longo do tempo.

De maneira semelhante, a ferramenta tem uma tela inicial, em que o usuário pode interagir com o banco de dados modificando as três variáveis principais: período, ator, e assunto relacionado ao tratado. A seleção temporal é feita com a data de entrada em vigor do tratado. A Figura 2.7. mostra as variáveis presentes para manipulação na tela inicial.

Figura 2.7. Tela Inicial da ferramenta de geração de relatório.

\begin{tabular}{|c|c|c|}
\hline $\begin{array}{l}\text { V Usar tratad } \\
\nabla \text { Usar tratad }\end{array}$ & $\begin{array}{l}\text { os multilater } \\
\text { os Bilaterais }\end{array}$ & \\
\hline Primeira data : & 19000101 & (aaaammdd) \\
\hline Última data: & 19991231 & \\
\hline Marcadores pa & ra a legend & \\
\hline 1. Zero & & \\
\hline 2. De 1 até & $: 5$ & \\
\hline 3. Do anterior & até : 10 & \\
\hline 4. Do anterior & até : 25 & \\
\hline 5. Do anterior & até : 50 & \\
\hline Do anterio & éo & \\
\hline 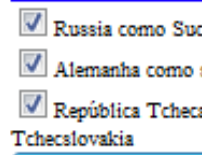 & $\begin{array}{l}\text { essora da URSS } \\
\text { ucessora da Alen } \\
\text { e Sloavalia com }\end{array}$ & $\begin{array}{l}\text { nanha Ocidental } \\
\text { lo sucessores da }\end{array}$ \\
\hline Fazer contag & em de insta & ncias do ator \\
\hline Fazer contag & em de inste & ncias de tipo \\
\hline Fazer co & tagem do & ator e tipo \\
\hline
\end{tabular}

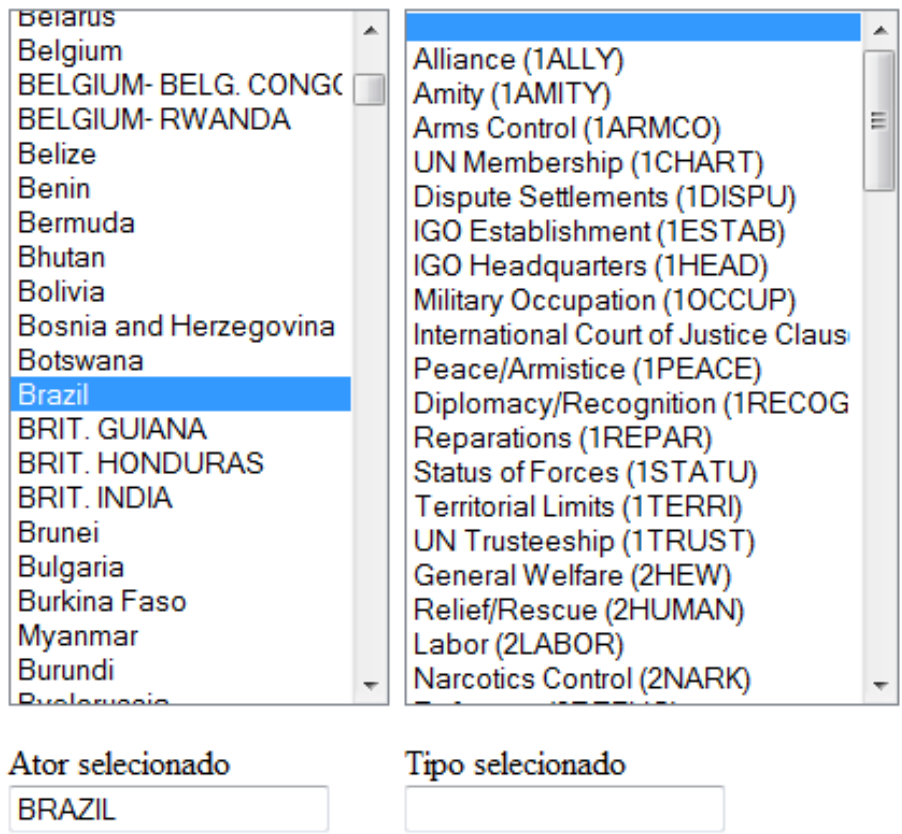

Fonte: Elaboração própria. Disponível para acesso em: treatypatterns.biz.nf/TreatyMaps.html.

Ao fazer as escolhas é possível representar os dados com base em a) um ator, b) um assunto, ou c) um assunto e um ator ao mesmo tempo. Em qualquer um destes casos o programa pesquisa a base de dados, contando todas as instâncias em que os critérios 
inseridos são atendidos. Com esta seleção o programa gera um mapa, um gráfico de barras e duas listas.

Se baseada num ator e se este fizer parte do mapa (é um ator territorial existente), esse ator base é marcado em verde. Todos os outros países ganharão diferentes tons de azul, quanto mais escuro maior a quantidade de tratados dele com o ator em verde. A Figura 2.8. representa uma seleção com base no Brasil de todos os seus tratados bilaterais no século XX.

Como as quantidades de tratados de cada ator ou assunto relativo podem variar bastante, as divisões na legenda entre os diferentes tons de azul deveriam ser maleáveis para que fossem produtivos em uma maior quantidade de possibilidades. Deixamos, deste modo, para o usuário a possibilidade de escolher os limites dos grupos de quantidades de tratados.

Figura 2.8. Mapa da distribuição espacial das quantidades de tratados bilaterais dos quais o Brasil é parte, 1900 - 2000.
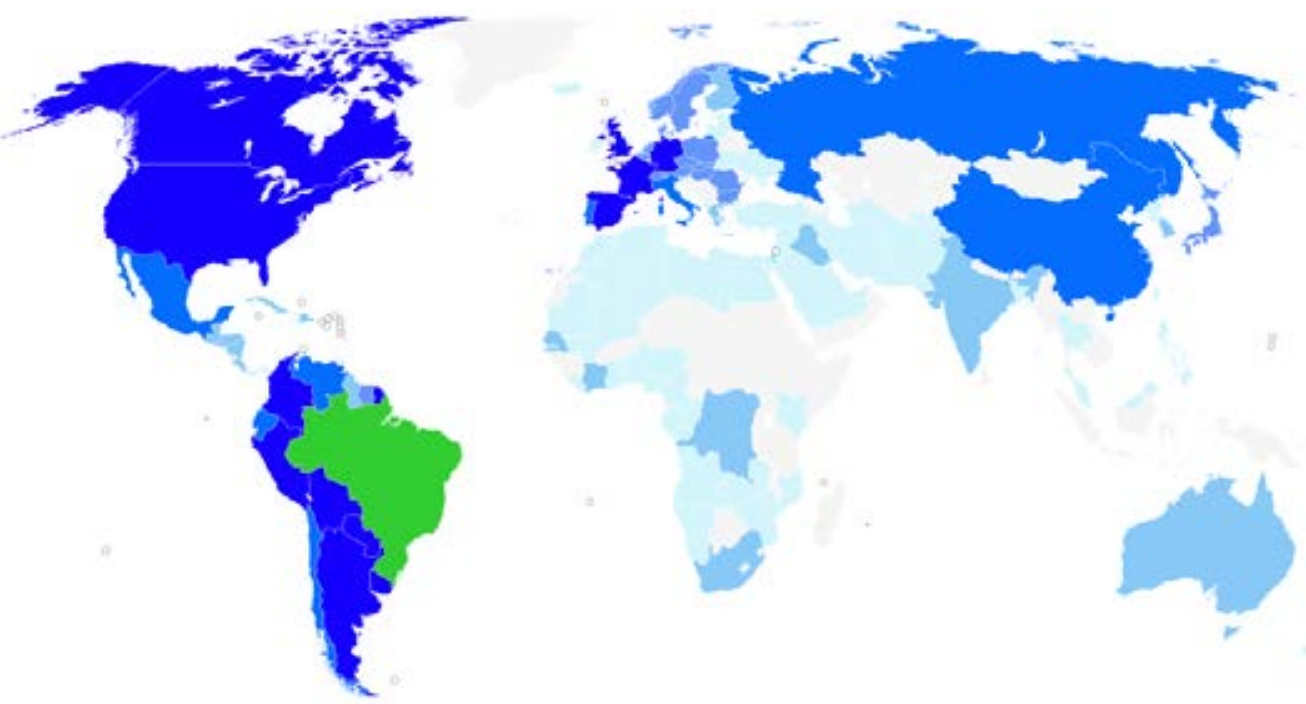

Fonte: Elaboração própria com base nos dados do World Treaty Index.

Nota: Em verde o Brasil, como ator selecionado. As especificações dos parâmetros usados nesta seleção são aqueles dispostos na Figura 2.7. 
Este mapa serve de bom exemplo para mostrar que esta forma de representação nos permite ver com muita facilidade a distribuição espacial dos tratados. É possível ver com clareza com quais atores territoriais o país selecionado faz mais ou menos tratados. Regionalismos são especialmente evidentes aqui, e como era de se esperar o Brasil fez mais tratados com as grandes potências e com os países próximos da América do Sul. Ao olhar o mesmo mapa o analista pode se perguntar os motivos de o Brasil ter certa quantidade de tratados com países como Congo e Iraque e buscar o detalhamento desta constatação. Do mesmo modo, ao interagir com atores de que se tem pouco ou nenhum conhecimento prévio pode-se rapidamente apreender estes padrões como informação útil e nova.

No entanto, esta ferramenta tem também desvantagens em relação à primeira ferramenta apresentada. O mapa mundial utilizado deixa de lado os atores não territoriais presentes no banco de dados e tem dificuldade de representar os atores territoriais que por algum motivo já não mais existem. O gráfico de dependência radial pode representar todos os atores sem esses limites, colocando ao mesmo tempo Rússia, União Soviética, e UNICEF como partes do anel central.

Tentamos contornar as dificuldades nas representações de atores territoriais extintos ou modificados adicionando a possibilidade de somar ao seu sucessor mais provável os tratados daquele ator extinto. Assim é possível escolher fazer ou não os contornos da atual Rússia representarem momentaneamente os tratados da extinta URSS e com isso ter uma ideia geral da distribuição com este ator sendo representado. Essa solução, apesar das vantagens, deve ser usada com os devidos cuidados, pois pode levar a enganos de interpretação se o usuário não tiver claro quais são os parâmetros usados.

A distribuição dos tratados ao longo do tempo pode ser acompanhada através de um gráfico de barras, que é gerado com a contagem de eventos da seleção ano a ano.

Percebe-se na Figura 2.9. que, ao contrário das outras representações visuais, neste caso utilizamos também os tratados multilaterais. Isso só é possível produtivamente neste gráfico dadas as características desse tipo de tratado ${ }^{9}$. Na tela inicial de controle

\footnotetext{
${ }^{9}$ Como se trata de contagem diática de instâncias há uma dificuldade em usar os tratados multilaterais, pois um único tratado poderia ser contado muitas vezes neste processo. Por exemplo, um tratado com seis participantes pode ser entendido como uma ligação de cada um deles para com todos os outros, totalizando quinze ligações. No caso específico da contagem anual o programa leva em conta somente uma única vez um
} 
demos a opção de escolha ao usuário de usar ou não estes dados. Com este gráfico é fácil acompanhar a evolução dos tratados ao longo do tempo, o que era difícil de fazer com a primeira visualização proposta. Possivelmente perceber quando um assunto se torna alvo de tratados pode ser tema relevante para alguns estudos de relações internacionais.

Figura 2.9. Gráfico de barras mostrando a distribuição temporal das quantidades de tratados dos quais o Brasil é parte, 1900- 2000.

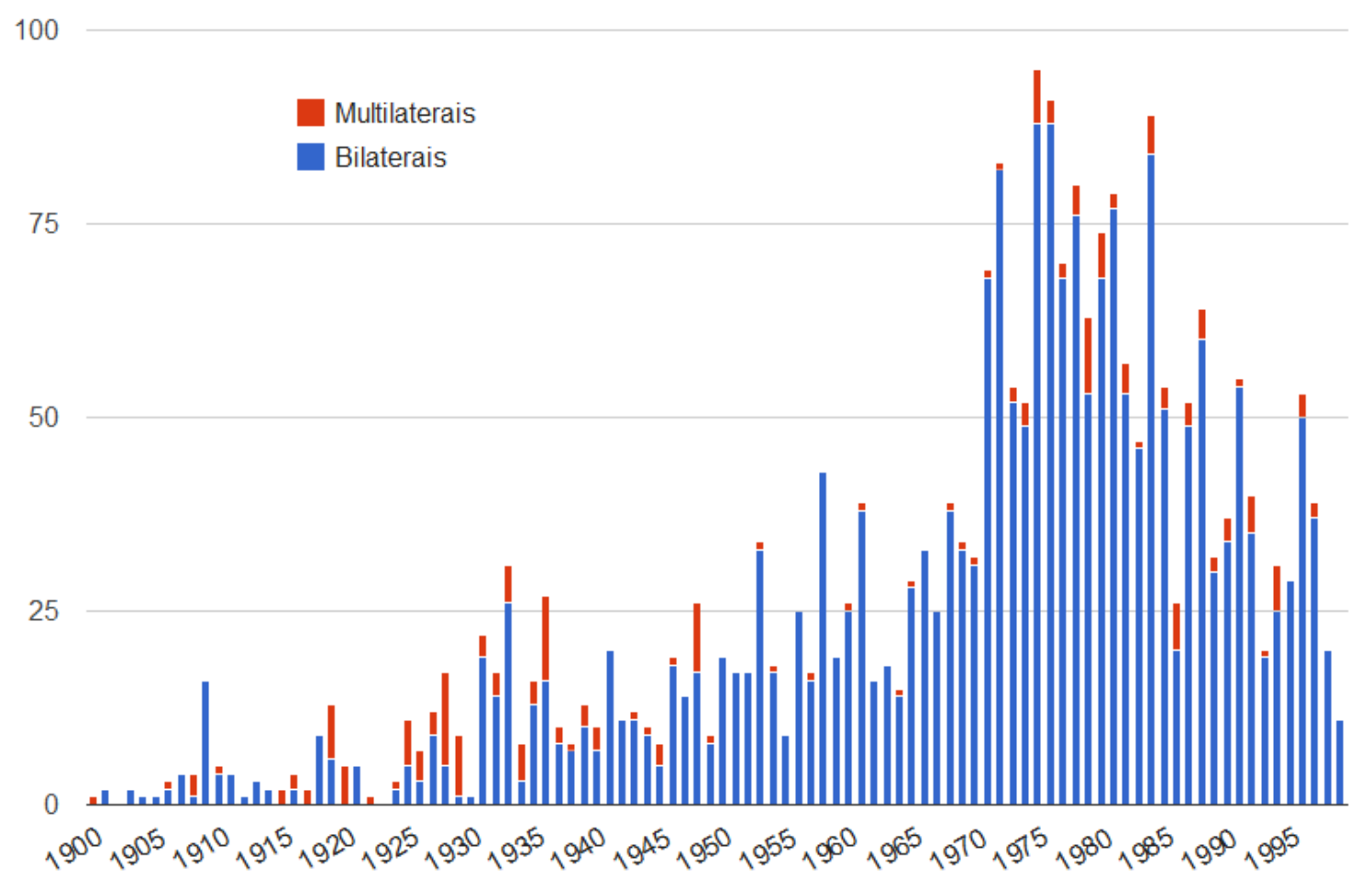

Fonte: Elaboração própria com base nos dados do World Treaty Index.

Nota: As especificações dos parâmetros usados nesta seleção estão dispostos na Figura 2.7.

Para completar esta segunda ferramenta adicionamos um gerador das listas dos vinte atores e assuntos com maiores quantidades numa dada seleção. Com isso é possível

tratado multilateral, quando ele foi primeiramente assinado para o caso da base escolhida pelo usuário ser um assunto (ex. todos os tratados classificados sob o assunto "militar"), ou quando o ator em questão o assinou quando a base escolhida pelo usuário para contagem for um ator (ex: todos os tratados do Brasil). Deste modo este problema não existe para a representação temporal.

É possível, embora isso não tenha sido feito aqui, pensar num procedimento de contagem de assinatura comum ao tratado multilateral para construir um mapa semelhante ao usado aqui desta feita somente com os tratados multilaterais. 
ver precisamente as quantidades e porcentagens relativas destas variáveis. A Figura 2.10. exemplifica este procedimento. Nestas listas utilizamos as siglas tanto dos atores quanto dos assuntos para reduzir o espaço necessário.

Figura 2.10. Tabela $A$ mostrando os atores com quem o ator selecionado (Brasil) faz mais tratados e suas porcentagens. Tabela B mostrando os assuntos mais freqüentemente relacionados aos tratados celebrados pelo Brasil; 1900 - 2000.

A

Lista dos atores com as maiores quantidades de tratados bilaterais e suas porcentagens relativas:

Nome do Ator Quantidade Porcentagem

$\begin{array}{ccc}\text { IBRD } & 235 & 10.14 \\ \text { GERMW } & 175 & 7.55 \\ \text { ARGENT } & 156 & 6.73 \\ \text { USA } & 152 & 6.56 \\ \text { BOLIVI } & 133 & 5.74 \\ \text { URUGUA } & 98 & 4.23 \\ \text { FRANCE } & 74 & 3.19 \\ \text { PARAGU } & 68 & 2.93 \\ \text { UK } & 63 & 2.72 \\ \text { SPAIN } & 60 & 2.59 \\ \text { CANADA } & 56 & 2.42 \\ \text { PERU } & 56 & 2.42 \\ \text { COLOMB } & 52 & 2.24 \\ \text { ITALY } & 46 & 1.99 \\ \text { PORTUG } & 46 & 1.99 \\ \text { VENEZU } & 43 & 1.86 \\ \text { MEXICO } & 40 & 1.73 \\ \text { CHINA } & 37 & 1.6 \\ \text { CHILE } & 36 & 1.55 \\ \text { ECUADO } & 32 & 1.38\end{array}$

B

\begin{tabular}{|c|c|c|}
\hline \multicolumn{3}{|c|}{$\begin{array}{l}\text { Lista dos tipos com as maiores } \\
\text { quantidades de tratados (bi e multilaterais) } \\
\text { e suas porcentagens relativas: }\end{array}$} \\
\hline Tipo & Quantidade & Porcentagem \\
\hline 4LOAN & 239 & 10.32 \\
\hline 3TRADE & 151 & 6.52 \\
\hline 4RESOU & 135 & 5.83 \\
\hline 4AGRIC & 105 & 4.53 \\
\hline ЗТЕCH & 99 & 4.27 \\
\hline 5AIR & 93 & 4.01 \\
\hline 7CULT & 87 & 3.75 \\
\hline 4TECA & 76 & 3.28 \\
\hline 3ECON & 64 & 2.76 \\
\hline IAMITY & 59 & 2.55 \\
\hline 9VISAS & 53 & 2.29 \\
\hline 3TAXAT & 50 & 2.16 \\
\hline IESTAB & 43 & 1.86 \\
\hline 9ADMIN & 42 & 1.81 \\
\hline 3COMMO & 40 & 1.73 \\
\hline 3PAYMT & 39 & 1.68 \\
\hline 9XTRAD & 38 & 1.64 \\
\hline 5LAND & 36 & 1.55 \\
\hline 7EDUC & 34 & 1.47 \\
\hline 7SCIEN & 34 & 1.47 \\
\hline
\end{tabular}

Fonte: Elaboração própria com base nos dados do World Treaty Index.

Nota: As especificações dos parâmetros usados nesta seleção estão dispostos na Figura 2.7. 


\section{CAPÍTULO 3. Os Dados}

\subsection{Introdução}

Como o objetivo do projeto é construir e avaliar uma representação visual de um conjunto de tratados, este capítulo intenta descrever as características mais relevantes desse conjunto que utilizaremos. Esse conjunto de tratados é resultado de uma série de fatores que tentaremos esmiuçar; das práticas dos Estados de utilizarem tratados como meio de interação; da codificação do direito internacional; dos procedimentos de compilação da ONU; da participação histórica da ONU, entre outros fatores.

São históricos e contextuais os passos que levam uma relação política internacional a culminar num documento internacional tal qual um tratado. Se este se enquadra no Artigo 102 da carta da ONU, o que já pressupõe algumas coisas (entre elas, o fato de que ao menos um dos signatários deve ser um membro da ONU), muito provavelmente este tratado será submetido a registro no Office of Legal Affairs (OLA) da ONU. Dentro do OLA o documento é submetido a alguns procedimentos de análise, registro, catalogação, agrupamento, tradução, etc., que verificam se o documento está apto para a publicação ou o habilitam para tal . Os procedimentos que o OLA segue se tornaram prática consolidada ao longo do tempo, que podem ser descritos em termos mais gerais do que os processos políticos subjacentes.

É importante diferenciar o banco de dados formado pelo Secretariado do banco de dados paralelo montado tendo por base o primeiro, mas com características próprias, seguindo as necessidades da ferramenta. O segundo é o resultado de uma série de procedimentos de seleção, transformação, compilação, baseados nos dados organizados pela ONU. É importante o fato de ser possível descrever as regras e procedimentos que o OLA adota para transformar os dados que recebe no seu banco de dados, assim como é importante descrever os procedimentos que tomaremos para transformar este banco de dados no nosso banco de dados paralelo. Esta descrição permitirá que o utilizador deste banco de dados saiba como os dados dele foram formados, e que fique assim ciente de suas distorções, evitando assumir alguns erros no momento da análise dos dados. Isto também aponta para o fato de que a análise desses dados tem limites claros: embora ela tenha por 
objetivo ajudar no entendimento das relações políticas internacionais, sozinha ela não permite qualquer análise política, a qual deve ser feita usando outros métodos das ciências sociais. A ferramenta tem clara intenção de ser somente um suporte, subsidiária de uma análise mais ampla, usando um conjunto de fontes e métodos diversos.

Se, partindo da base de dados existente, utilizarmos a ferramenta de representação visual, não ficaria explícito como se formaram esses dados, o que estaria de fora, e os motivos para inclusões e ausências. Essas informações são essenciais para que o utilizador avalie corretamente os dados que vê e manipula. Este capítulo procura justamente tornar explícito como foi formado este conjunto de dados, detalhando A) os procedimentos que os atores internacionais perfazem na área relativa a tratados, B) os procedimentos de registro e publicação do Secretariado da ONU, C) o desenvolvimento dos atores envolvidos neste conjunto de dados, e D) os procedimentos que usamos para selecionar, compilar, transformar quando preciso, e organizar os dados do Banco de dados da ONU, construindo assim um Banco de Dados paralelo, apto a ser base para a ferramenta de representação visual proposta.

Este capítulo inicia, portanto, com a descrição do banco de dados formado pelo OLA. Essa primeira parte compreende os motivos para sua formação, os parâmetros dos dados, os atores envolvidos, e os procedimentos de transformação dos dados.

Em segundo lugar descrevemos os procedimentos que adotamos para construir, usando como fonte o banco de dados do OLA, o nosso próprio banco de dados com suas características distintas.

\subsection{Tratados}

\subsubsection{O Artigo 102 da Carta das Nações Unidas}

Em 24 de outubro de 1945 a Carta das Nações Unidas entra em vigor depois de muitas discussões na sua elaboração, sendo assinada por 51 Estados. Dentre seus artigos, o de número 102 versa sobre a publicação de todos os tratados que porventura um EstadoMembro possa assinar. O Artigo 102 é composto por dois parágrafos: 
Paragraph 1: Every treaty and every international agreement entered into by any Member of the United Nations after the present Charter comes into force shall as soon as possible be registered with the Secretariat and published by it.

Paragraph 2: No party to any such treaty or international agreement which has not been registered in accordance with the provisions of paragraph 1 of this Article may invoke that treaty or agreement before any organ of the United Nations.(ONU[a], 1945. Artigo 102)

O primeiro parágrafo deixa explícita a necessidade de registro de todos os tratados e acordos internacionais feitos pelos assinantes da Carta da ONU, e acrescenta como dever do Secretariado das Nações Unidas a publicação desses documentos. O segundo parágrafo esclarece a conseqüência em caso de não cumprimento dos requisitos do primeiro parágrafo, qual seja, a impossibilidade de invocar tais documentos perante qualquer órgão das Nações Unidas.

A ideia que levou as Nações Unidas a adotarem tal requisição em sua carta fundadora pode ser encontrada anteriormente no pensamento liberal, e famosamente no primeiro dos quatorze pontos de Woodrow Wilson ${ }^{10}$. Ao fim da primeira guerra Wilson clama pela eliminação total de toda diplomacia secreta. Ele acreditava que quanto mais transparentes fossem as ações dos Estados mais fortalecidas estariam as ligações de paz entre eles, e que a diplomacia secreta acentuava a instabilidade internacional e a possibilidade de conflito (ONU[d], 2006, p.26).

A Liga das Nações, formada pouco tempo depois com apoio do próprio Wilson, reflete o mesmo pensamento no seu $18^{\circ}$ Artigo: "Every treaty or international engagement entered into hereafter by any Member of the League shall be forthwith registered with the Secretariat and shall as soon as possible be published by it. No such treaty or international engagement shall be binding until so registered" (LIGA DAS NAÇÕES, 1919, Artigo 18). Este artigo serviria de base para o Artigo 102 da Carta das Nações Unidas, a diferença ficando por conta da inexistência da necessidade de registro para formalizar o contrato entre as partes no Artigo 102 da Carta de 1945. Portanto o espírito no tema da publicidade

\footnotetext{
10 "Open covenants of peace, openly arrived at, after which there shall be no private international understandings of any kind but diplomacy shall proceed always frankly and in the public view."(WILSON, 1918)
} 
dos tratados é o mesmo para a Liga das Nações e para as Nações Unidas (ONU[h], 1955, parag. 38).

Em 1946 foram aprovadas pela Assembléia Geral as Regulações para dar Efeito ao Artigo 102 (ONU[c]) (doravante Regulações). Elas definem as práticas a serem tomadas para o cumprimento do artigo em questão. Duas medidas das Regulações são de grande importância. A primeira é o entendimento de que só se deve registrar tratados e acordos internacionais já em vigor para pelo menos duas partes contratantes (Artigo 1(2)). A segunda afirma que quando um tratado ou acordo internacional for registrado de acordo com o Artigo 102, todas as ações subseqüentes que perfaçam uma mudança nas partes, nos termos, no escopo, ou na aplicação de tal tratado deverão ser também registradas e publicadas pelo Secretariado (Artigo 2(1)).

No entanto, o Artigo 102, bem como suas Regulações, se destaca também pela falta de uma definição explícita do que vêm a ser considerados 'tratados' e 'acordos internacionais'.

\subsubsection{Definição de tratados e acordos internacionais}

A única elaboração das Regulações sobre a definição de 'tratados' e 'acordos internacionais' foi a de explicitar a grande amplitude de aplicações destes ao adicionar no seu primeiro parágrafo a frase "whatever its form and descriptive name" (ONU[c], Artigo 1(1)). Deste modo, neste seu âmbito legal geral, 'convenções', 'protocolos', ‘trocas de cartas', 'trocas de notas', 'convênios', 'memorandos de entendimento', ou 'estatutos', todos podem ser tomados legalmente como 'tratados' ou 'acordos internacionais'.

Em nota o Secretariado reafirma que não há definições para estes termos-chave e que sua prática em relação a isso será a de agir em concordância com seus EstadosMembros. Quando um Estado submete um documento para registro, o Secretariado entende que este documento foi considerado por este Estado um tratado ou acordo internacional no significado dado pelo Artigo 102 (ONU[c], Anexo ${ }^{11}$ ). Agindo assim o Secretariado se isenta da responsabilidade de decidir o status de um documento, enfatizando que o registro ou mesmo a publicação de um documento não implica um julgamento do Secretariado nem

\footnotetext{
${ }^{11}$ A mesma informação pode ser encontrada no United Nations, Treaty Series, Vol. 1, p. XXVIII.
} 
concede ao documento ou às partes um status que estes já não tivessem. Este entendimento veio na década de 1950 como reflexo das ações de Estados Unidos, Inglaterra e República Democrática da China (Taiwan), que protestaram contra o registro de tratados feitos por Estados que estes não reconheciam (CONFORTI, 2005, p.271).

Em última instância, assim, fica a cargo do Estado-Membro a decisão de enquadrar ou não um documento como um tratado no âmbito do Artigo 102, o que traz conseqüências para a formação do banco de dados. Foi só a partir de 1969, com a Convenção de Viena sobre os Direitos dos Tratados (C.V.), que a definição de 'tratado' ganha contornos mais específicos:

'[T]reaty' means an international agreement concluded between States in written form and governed by international law, whether embodied in a single instrument or in two or more related instruments and whatever its particular designation. (C.V., 1969, Article 2(1)(a))

Desde sua criação, a Convenção de Viena é usada como guia ${ }^{12}$ pelo Secretariado para o tratamento das disposições do Artigo 102. Com base nesses guias, a ONU clarifica para sua própria prática os termos relevantes. Assim, de acordo com o Treaty Reference Guide da ONU, para ser considerado tratado é preciso a) que seja um instrumento de contrato (binding instrument), o que significa que as partes contratantes tem a intenção de criar direitos e deveres legais entre elas; b) que o instrumento seja concluído por Estados ou Organizações Internacionais com o poder de celebrar tratados; c) que o instrumento seja governado pelo Direito Internacional; d) que ele esteja em forma escrita (ONU[e], 1999, p.3).

Um tratado deve impor às partes obrigações legais de contrato sob o direito internacional, e não meros comprometimentos políticos. Deve ser claro à primeira vista do instrumento, seja qual for sua forma, que as partes intentam estar legalmente em contrato sob o jugo das leis internacionais. Já ocorreu de o Secretariado concluir que um instrumento submetido a registro, referente à criação de uma associação de parlamentares, não era um tratado ou acordo internacional porque não criava direitos e deveres sob o júdice do direito internacional (ONU[d], 2006, p.27).

\footnotetext{
${ }^{12}$ Soma-se ainda ao corpus que guia a prática do Secretariado sobre o Artigo 102 a Convenção de Viena de 1986 que regula o direito internacional dos tratados em relação às Organizações Internacionais.
} 
Podemos acrescentar aqui, referente somente ao entendimento do Artigo 102 sobre o que é um tratado registrável, que fica implícito que o tratado deve estar em vigor para que ele possa ser registrado (ONU[c], Artigo 2).

Os termos desses quatro documentos e as práticas da ONU através de seu Secretariado e dos Estados-Membros definem em conjunto o que exatamente virá fazer parte do Banco de Dados de tratados desta instituição.

\subsubsection{Poder de celebrar tratados}

O poder de celebrar tratados é assumido como parte da soberania de qualquer Estado. A Convenção de Viena de 1969 reafirma isso no seu parágrafo sexto. A questão se torna, portanto, se tal entidade política pode ser considerada um Estado soberano e conseqüentemente se tem o poder de celebrar tratados (ou se é uma Organização Internacional com estes poderes). Apesar de várias tentativas esta questão não é determinada por nenhum conjunto legal, mas sim por processos políticos particulares. Uma entidade política pode ser reconhecida como Estado soberano por uns e não por outros, o que possibilitaria o evento de um tratado ser feito entre dois Estados, um deles tendo seu status contestado por terceiros. Isto pode ficar ainda mais problemático porque se pode argumentar que um dos critérios de soberania seria justamente o poder de celebrar tratados, logo a intenção por parte de alguns de não aceitar o poder de celebrar tratados para evitar dar margem ao reconhecimento de soberania.

No que tange à prática do Secretariado em relação aos registros dos tratados, este novamente se exime da responsabilidade de definir o poder de celebrar tratados. $\mathrm{O}$ Secretariado considera que se o Estado-Membro que coloca um documento a registro entende que a segunda parte contratante é um Estado soberano (e que, portanto, tem o poder de celebrar tal tratado), o Secretariado deve proceder para o registro. A República Democrática da China (Taiwan) só é reconhecida como Estado por pequena parte da comunidade internacional, e já teve sua petição para ser Estado-Membro da ONU negada pelo menos quatorze vezes desde que foi excluído da ONU em 1971; mesmo assim, está representada no Banco de Dados de tratados do UNTC, pois se um Estado-Membro da ONU considerou-a como Estado soberano e celebrou um tratado com ela, a ONU não se 
opõe ao registro deste instrumento. Novamente este ponto é importante para definir que documentos fazem parte do Banco de Dados, o que irá refletir na representação visual e seu entendimento.

A possibilidade das partes de uma Federação de Estados terem o poder de celebrar tratados ainda é hoje questão controversa na codificação do direito internacional, o que nunca impediu que a prática geral fosse claramente a de aceitar tais ações ${ }^{13}$. Dada a necessidade de consentimento legal da Federação para que suas partes tenham o poder de celebrar tratados, a Federação é considerada a responsável por estes tratados perante o direito internacional (AUST, 2005, p.58).

As Organizações Internacionais também tiveram, na prática do direito internacional, reconhecida sua capacidade de realizar tratados, o que ficou cada vez mais evidente na medida em que ao longo do século XX essas organizações cresceram em quantidade e escopo de atividade.

A possibilidade de codificação do direito dos tratados firmados entre Estados e Organizações Internacionais, ou entre duas ou mais Organizações Internacionais, também foi alvo de longo debate, sendo incluída na maioria das discussões sobre a Convenção de Viena de 1969, mas deixada de lado da sua redação final (DOBBERT, 1987, p.6). A codificação veio com um texto específico para estes casos com a Convenção de Viena de 1986. Apesar de ainda não estar em vigor por falta de ratificações suficientes, seu artigo sexto provê que a capacidade para celebrar tratados por tais organizações é dada pelas regras da própria organização.

Indivíduos e empresas, mesmo as transnacionais, não têm a capacidade de celebrar tratados reconhecida ${ }^{14}$.

${ }^{13} \mathrm{O}$ assunto foi discutido longamente na segunda conferência sobre os leis dos tratados (ONU[f], 1969, pp. 7-16), que culminou no texto da Convenção de Viena de 1969. De acordo com versões preliminares da Convenção de Viena de 1969, as partes de uma Federação de Estados podem ter o poder de celebrar tratados desde que este poder seja admitido pela constituição federal e dentro dos limites por ela impostos. Este era o caso, por exemplo, das Repúblicas Soviéticas, que tinham grande interesse em que isto se mantivesse na versão final da Convenção, o que não ocorreu embora também não tenha sido proibida.

${ }^{14}$ A Corte Internacional de Justiça decidiu em 1952 que os documentos firmados pela Anglo-Iranian Oil Company e pelo governo do Irã eram contratos e que não poderiam ser tomados como tratados, contrariando o que argumentavam os representantes britânicos (International Court of Justice, 1952, Rep. 93). 


\subsubsection{Consentimento de obrigar-se por um tratado (consent to be bound)}

O mais significativo ato que um Estado ou Organização Internacional pode tomar em relação a um tratado é o ato de consentir em obrigar-se por um tratado (consent to be bound) (AUST, 2005, p.62). Um Estado pode expressar sua intenção de obrigar-se por um tratado por meio da assinatura definitiva, pela troca de cartas constituindo um tratado, pela ratificação, pela adesão a um tratado, pela aceitação ou aprovação, ou por qualquer outro meio definido pelas partes (C.V., 1969, Artigo 11).

É importante frisar a separação do ato de obrigar-se a um tratado e a entrada em vigor do mesmo. Apesar de ser possível que estas datas sejam as mesmas (quando por exemplo a entrada em vigor ocorre no momento da assinatura, de acordo com as provisões deste tratado), o mais comum, especialmente em acordos multilaterais, é que as duas datas sejam distintas. A Convenção de Viena de 1969 define como 'Estado contratante' aquele que realizou o ato de se obrigar por um tratado, mesmo que esse tratado não tenha ainda entrado em vigor. 'Estado parte', por outro lado, é aquele que já consentiu em obrigar-se por um tratado e para quem este tratado já está em vigor (CV., 1969, Artigos 2(1)(f, g)). Somente quando um tratado entra em vigor é que ele obriga as partes a cumpri-lo (C.V., 1969, Artigo 26), criando direitos e deveres entre as partes, regidas pelo direito internacional.

No entanto, o ato de obrigar-se a um tratado (não confundir com a obrigação imposta pelo tratado em vigor), ou seja, assinatura, adesão, ratificação, ou outro instrumento, mesmo que ainda faltante a entrada em vigor do tratado, ainda assim gera algumas obrigações. De acordo com o artigo 18 da Convenção de Viena de 1969, depois de consentir em obrigar-se por um tratado, o Estado é obrigado a abster-se de praticar atos que frustrariam o objeto e a finalidade desse tratado, mesmo que ele ainda não tenha sido ratificado pelo país (quando isto é necessário) ou que ainda não tenha entrado em vigor. Este ponto pode causar confusão, pois este artigo não obriga o Estado contratante a agir de acordo com o tratado que, apesar de assinado, ainda não entrou em vigor. Tudo o que o Estado contratante não pode fazer é qualquer coisa que afete a sua capacidade de cumprir o tratado se e quando este vier a entrar em vigor (AUST, 2005, p.66). Em suma, o Estado 
contratante não pode agir de forma que sua ação invalide os propósitos básicos do tratado cuja entrada em vigor ainda pende.

\subsubsection{Entrada em vigor e outras ações referentes a tratados.}

Há algumas ações referentes a tratados que podem ser diferenciadas, sendo as mais comuns: assinatura, ratificação, adesão, aceitação, aprovação, denúncia, saída, término, retificações e emendas. Devemos ainda olhar com um cuidado especial a entrada em vigor, pois este é o critério para registro do tratado junto ao Secretariado (ONU[c], Artigo 1(2)).

A assinatura pode ser definitiva ou simples (ONU[d], 2006, p.64). A primeira se refere àquela que expressa a intenção do Estado em obrigar-se por um tratado sem que esta assinatura necessite de ratificação, aceitação ou aprovação (C.V., 1969, Artigo 12). A assinatura pode ser também simples, o que significa que, para se tornar um consentimento de obrigar-se por esse tratado, ela necessita ainda de ratificação, aceitação ou aprovação. A assinatura simples é usada na maioria dos tratados multilaterais.

Ratificação, aceitação e aprovação têm, para os efeitos dos tratados, o mesmo valor e significado, que é o do consentimento de obrigar-se perante um tratado (AUST, 2005, p.64). Ratificação como ato internacional ${ }^{15}$ requer a execução de um instrumento em nome do Estado. No caso dos tratados bilaterais, isso é feito por meio da troca de instrumentos de ratificação e, no dos multilaterais, por meio do registro com o depositário (AUST, 2005, p.64). A razão mais comum para a necessidade da ratificação é conferir o tempo necessário ao Estado contratante depois da assinatura simples para que este se adéqüe antes de dar seu consentimento a obrigar-se pelo tratado. É muito comum, por exemplo, que sejam necessárias mudanças na legislação interna do Estado, ou que este passe por um processo de ratificação nacional parlamentar antes que seja capaz de dar seu consentimento a obrigar-se internacionalmente.

\footnotetext{
${ }^{15}$ A ratificação internacional não deve ser confundida com o processo de ratificação nacional, mormente parlamentar, muitas vezes necessário em relação aos tratados em vários Estados (pode-se dizer em muitos casos que um tratado requer ratificação nacional como pressuposto para este Estado ter o poder de ratificar internacionalmente o tratado em questão).
} 
Note-se que mesmo ratificado o tratado ainda não provê direitos e deveres sob as leis internacionais (exceto aqueles descritos pela aceitação em obrigar-se a um tratado), o que só ocorre quando este entra em vigor para o dado Estado, ou seja, somente quando o Estado deixa de ser 'contratante' e se torna 'parte' deste tratado (C.V., 1969, Artigo $2(1)(g))$.

A entrada em vigor de um tratado é o momento em que este se torna legalmente um instrumento de contrato entre as partes (que consentiram em obrigar-se pelo tratado), criando direitos e deveres no âmbito do direito internacional (AUST, 2005, p.77). A data da entrada em vigor de forma definitiva para um tratado é normalmente acordada nas provisões do instrumento. Geralmente é uma data especifica ou quando algumas condições são cumpridas - por exemplo, quando um certo número definido de Estados, ou uma certa porcentagem de Estados, depositar instrumentos de ratificação, aceitação, aprovação ou $\operatorname{adesão}^{16}$ (ONU[d], 2006, p.20). Uma vez que um tratado entre em vigor, mesmo que posteriormente o número de partes caia abaixo do mínimo dado em suas provisões para entrada em vigor, esse tratado continua em vigor a não ser que o próprio tratado indique o contrário (C.V., 1969, Artigo 55).

A entrada em vigor provisória pode ser permitida pelos termos de um tratado, dando margem a que Estados que já estão prontos para implementar as obrigações de um dado tratado o façam entre si, sem ter de esperar pelo cumprimento das condições da entrada em vigor definitiva (ONU[d], 2006, p.21). Quando um tratado entra em vigor provisoriamente ele cria obrigações entre as partes (e somente entre estas) que concordaram fazê-lo entrar em vigor desta maneira (C.V., 1969, Artigo 25(1)). Um bom exemplo é o General Agreement on Tariff and Trade (GATT), que nunca entrou em vigor na sua forma

\footnotetext{
${ }^{16}$ Alguns exemplos de provisões para entrada em vigor são:

"A) Protocol relating to the Status of Refugees, 1967: "The present Protocol shall come into force on the day of deposit of the sixth instrument of accession".

B) Rome Statute of the International Criminal Court, 1998: "This Statute shall enter into force on the first day of the month after the $60^{\text {th }}$ day following the date of the deposit of the 60th instrument of ratification, acceptance, approval or accession with the Secretary-General of the United Nations."

C) International Coffee Agreement 2001, 2000: "This Agreement shall enter into force definitively on 1 October 2001 if by that date Governments representing at least 15 exporting Members holding at least 70 percent of the votes of the exporting Members and at least 10 importing Members holding at least 70 percent of the votes of the importing Members, calculated as at 25 September 2001, without reference to possible suspension under the terms of Articles 25 and 42, have deposited instruments of ratification, acceptance or approval. ..."(ONU[d], 2006, p.20)
} 
final, mas somente pelo seu protocolo de aplicação provisória, a partir de 1948 (ONU[g], 1999, parag. 237).

Os tratados multilaterais têm comumente um período para assinatura, depois do qual a forma mais comum de fazer parte deste é através de um documento de adesão (se assim o tratado definir como possível (C.V., 1969, Artigo 15)). A adesão (em inglês accession) equivale legalmente ao ato de ratificação, e, portanto, implica no consentimento em obrigar-se pelo tratado.

\subsubsection{Duração e extinção de um tratado}

Não devemos nos ater aqui aos motivos pelos quais os tratados deixam de ter validade ou aplicabilidade $^{17}$, mas somente às formas utilizadas para que isso aconteça. A qualidade dinâmica dos tratados, tanto na sua feitura, quanto na sua extinção, faz o banco de dados formado se complexificar e pedir formas de tratar estes casos; agora nos ateremos somente à tarefa de apresentar estas formas.

Alguns tratados têm no seu corpo provisões indicando uma data de término deste, quando ele se torna 'extinto'. No entanto, na maioria das vezes, entende-se que um tratado tem aplicação indeterminada. Há casos de tratados em vigor há mais de $350 \operatorname{anos}^{18}$.

Há algumas formas padrão de ação dos Estados e Organizações Internacionais para agir de forma a fazer tratado do qual este é parte deixar de ter validade para ele. No caso dos tratados bilaterais o ato da 'denúncia' (denunciation) e no caso dos multilaterais a 'saída' ou 'retirada' (withdrawal) servem para este propósito. Ambos são atos unilaterais. A denúncia é o ato pelo qual um ator internacional deixa explícito que não mais se considera parte de um tratado; a denúncia de um tratado bilateral legalmente feita implica necessariamente na sua extinção (AUST, 2005, p.100). Já a retirada de uma das partes de um tratado multilateral não afeta a continuidade nem a aplicabilidade deste entre os atores que continuam partes deste instrumento. Um tratado multilateral pode ainda ser extinto por

\footnotetext{
${ }^{17}$ Para uma tentativa de codificação destes motivos em uso pela direito internacional veja a Convenção de Viena de 1969, Parte V. Para uma discussão destes motivos ver Anthony Aust (2005, pp.100-108).

${ }^{18}$ Em 2004 a Suécia e a Grã-Bretanha celebraram o 350 aniversário do Tratado de Paz e Comércio concluído entre a rainha Christina e Oliver Cromwell (AUST, 2005, p.107).
} 
outro tratado multilateral quando todos os membros do primeiro são também do segundo (ONU[g], 1999, parags. 256-262)

Alguns tratados multilaterais de direitos humanos (como International Covenant on Civil and Political Rights, 1966) não contêm provisões para a retirada de uma de suas partes. O Secretariado como depositário vem adotando o ponto de vista de que não seria possível para uma das partes sair de tal tratado através de sua retirada (ONU[d], 2006, p.25).

Tais quais as emendas e retificações, as denúncias, retiradas e extinções modificam os tratados e devem portanto, de acordo com as Regulações, ser registradas junto ao Secretariado das Nações Unidas pelos Estados-Membros para que sejam publicadas (ONU[c], Artigo 2).

\subsubsection{Registro dos tratados junto ao Secretariado da ONU}

Para ser registrado um tratado tem que preencher certos requisitos: a) o instrumento deve ser um tratado ou acordo internacional no significado do Artigo 102. Como vimos acima (sessão 3.2.2.), este pode ser tema de controvérsias que o Secretariado deixa a cargo dos Estados. Apesar da falta de definição precisa, o termo 'tratado' é assumido como criando um contrato que implica direitos e deveres entre as partes, regidos pelo direito internacional; b) as partes de um tratado devem ter o poder de celebrar tratados (o que pode ser assunto controverso em alguns casos, veja sessão 3.2.3. deste trabalho), ou seja, ser consideradas sujeitos de Direito Internacional Público; c) é preciso que o tratado já tenha entrado em vigor (veja sessão 3.2.5.).

Além dos tratados todas as ações subseqüentes que modifiquem o tratado, tais como, retificações, reservas, ou mesmo a extinção do tratado, devem ser submetidas do mesmo modo a registro (ONU[c] Artigo 2). Se ocorre de um tratado modificar um tratado anterior não registrado, este deve ser primeiramente registrado para que o segundo também o possa $\operatorname{ser}^{19}$.

\footnotetext{
${ }^{19}$ O Secretariado registra os dois documentos sob o mesmo número de registro para fins de organização (ONU[d] 2006, p.31).
} 
A obrigação de levar a registro os tratados recaí sobre os Estados-Membros da ONU, assinantes da sua Carta, mas quando uma das partes faz o registro isso libera todas as outras desta responsabilidade ${ }^{20}$ (AUST, 2005, p.111). Isto não impede ainda que Estados não-membros ou que Organizações Internacionais coloquem instrumentos de que são parte junto com Estados-Membros a registro (ONU[d], 2006, p.28).

Como fica claro pelo segundo parágrafo do Artigo 102, a conseqüência de não cumprir com os requisitos desse artigo é a impossibilidade do tratado poder ser invocado por qualquer uma das suas partes perante algum órgão da ONU. No entanto, como lembra Anthony Aust (2002, p.280), o órgão judicial de maior relevância da ONU, a Corte Internacional de Justiça, não aplica estritamente esta provisão, o que é comprovado por alguns casos julgados. O autor argumenta ainda que é impensável que o Conselho de Segurança não leve em conta um tratado somente por falta do devido registro.

Há ainda algumas exceções dignas de nota. De acordo com as Regulações (ONU[c], Artigo 10) o Secretariado deverá registrar e arquivar os seguintes grupos de tratados mesmo que estes não se encaixem sob o Artigo 102 da Carta: a) tratados feitos pela ONU ou por uma de suas agências especializadas; b) tratados enviados por algum dos seus Estados-Membros que entraram em vigor antes da entrada em vigor da Carta da ONU; c) tratados enviados por não-membros da ONU, não importando se entraram em vigor antes ou depois da Carta $^{21}$. Nos dois últimos casos isto será ignorado se o tratado já tiver sido registrado e publicado pela Liga das Nações. Quando a própria ONU for parte de um tratado, quando ela é seu depositário (no caso de tratados multilaterais), ou quando a parte é uma de suas agências especializadas, o Secretariado deve registrar os documentos de forma ex-officio (ONU[c], Artigo 4; ONU[d], 2006, p.29).

\footnotetext{
${ }^{20}$ Pode ocorrer, no entanto, que um documento seja tomado com um tratado por uma das partes e não por outra, embora isto seja raro (AUST, 1986, p.803).

${ }^{21}$ Em Resolução da Assembléia Geral da ONU em 1946 foi recomendado enviar uma nota a todos Estados, mesmo não membros, pedindo que levassem seus tratados para serem catalogados e arquivados pelo Secretariado (GA Resolution 23). Ver também ONU[g], 1954, parags. 7-8 e p. 291). Apoiado também nesta prática, o artigo 80 da Convenção de Viena de 1969 exige que seus membros registrem todos os seus tratados junto ao Secretariado da ONU, mesmo que não sejam Estados-Membros desta. O Secretariado registra estes documentos mas os publica em separado no UNTS (AUST, 2002, p.278). Veja em mais detalhes sobre a publicação na sessão 3.2.8. deste trabalho.
} 
Ao receber um tratado o Secretariado (representado pela Sessão dos Tratados do Office of Legal Affairs (OLA)) analisa se os requisitos burocráticos do registro estão preenchidos. Verifica prima facie se este se trata de um tratado (ONU[d], 2006, p.26); se tem as assinaturas de uma autoridade com plenos poderes ${ }^{22}$; se a cópia do tratado com todos os documentos referidos estão completos (ONU[d], 2006, p.30); se os documentos provêem as informações de registro necessárias, tais como data de entrada em vigor, método de entrada em vigor, local e data da conclusão do documento (ONU[d], 2006, p.31); e finalmente se junto aos documentos do tratado está um documento que certifique (certifying statement) que os documentos apresentados são verdadeiros, completos e que incluem todas as reservas feitas pelas partes (ONU[c], Artigo 5).

As Figuras 3.1. e 3.2. abaixo mostram o crescimento da quantidade de tratados registrados no OLA ao longo da existência da ONU. A primeira figura mostra as quantidades absolutas, e a segunda a evolução da média por ator internacional, em que se percebe tendência de queda na média pois o número de atores no sistema aumentou consideravelmente.

\footnotetext{
${ }^{22}$ Chefe de Estado, Chefe de Governo ou Ministro das Relações Exteriores tem plenos poderes de agirem em nome do seu Estado, qualquer outro precisa de um instrumento que estenda a ele estes poderes (C.V., 1969, Artigo 7; ONU[d], 2006, p.6).
} 
Figura 3.1. Quantidade de tratados em vigor e extintos por ano, com linha de tendência, 1945-2008.

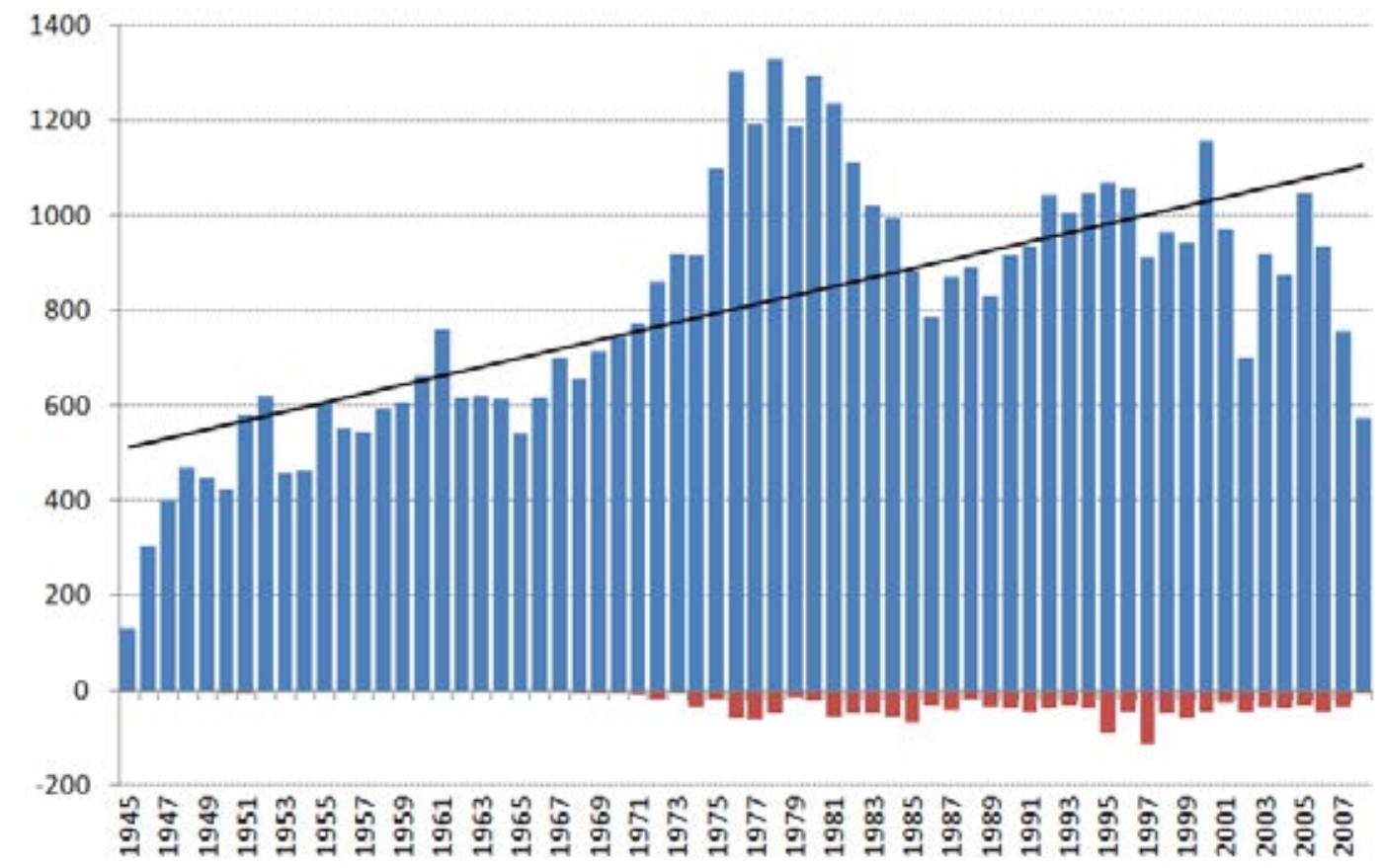

Fonte: UNTS, compilação própria. Nota: Em vermelho os términos, em azul em vigor.

Figura 3.2. Número médio de tratados bilaterais registrados no UNTS por ano por Estado Membro da ONU, 1945-2008.

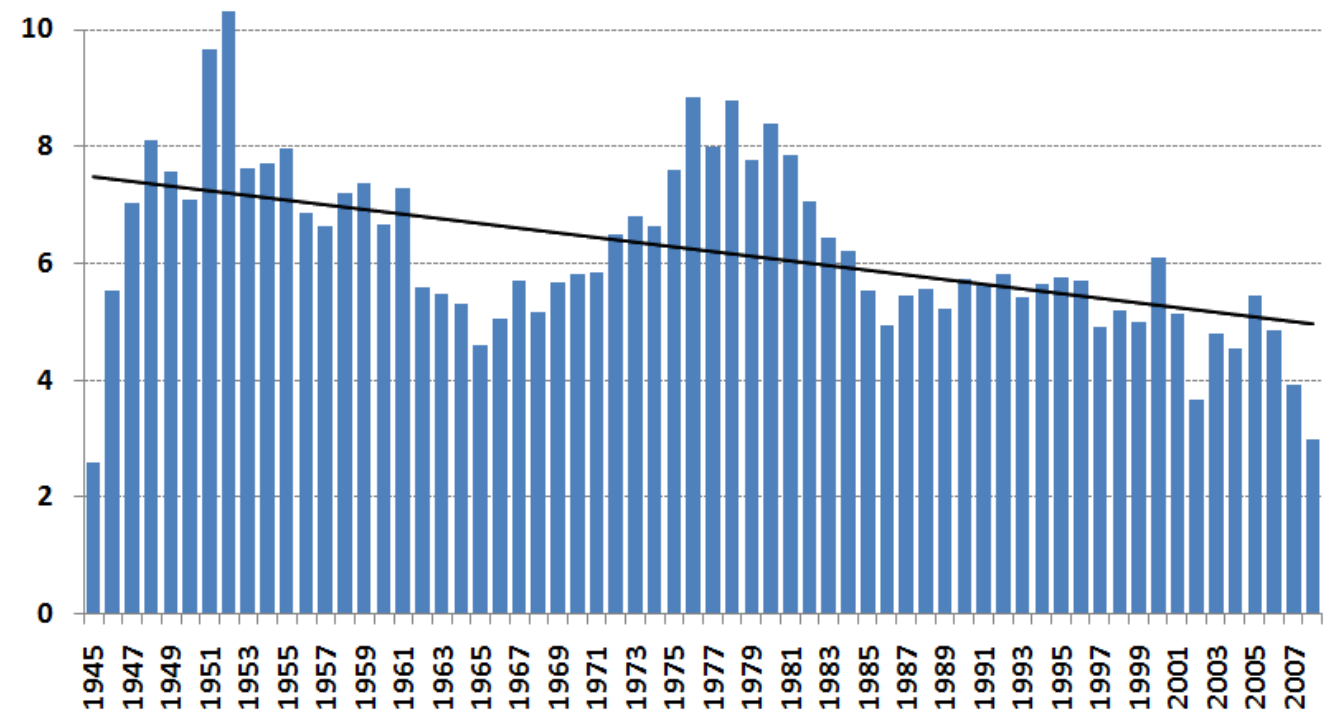

Fonte: UNTS, compilação própria. Número de Estado Membros da ONU por ano http://www.un.org/en/members/growth.shtml. 


\subsubsection{Arquivamento e publicação dos tratados pelo Secretariado}

$\mathrm{O}$ arquivamento também tem suas regras e padrões. O Artigo 8 das Regulações (ONU[c]) define quais informações devem ser associadas aos documentos registrados, o que vale tanto para tratados quanto para suas ações subseqüentes: a) um número de série, dado por ordem de registro; b) o título dado pelas partes ao instrumento; c) o nome das partes que concluíram o documento; d) a data e local de assinatura, ratificação, aceitação ou adesão e a data da entrada em vigor; e) a duração (quando apropriado); f) a língua do original do documento; g) o nome da parte que registra o documento (podendo ser uma agência especializada); h) informações particulares sobre a publicação no United Nations Treaty Series (UNTS). O Treaty Handbook (ONU[d], 2006, pp. 32-33) soma ainda a estas informações a data de recebimento dos instrumento pelo Secretariado e a data do registro ou catalogação.

Aqueles documentos que o Secretariado recebe fora do âmbito do Artigo 102 (descritos na sessão anterior) são catalogados, arquivados e publicados em separado. Notese que o Secretariado evita usar a palavra registro para estes documentos para evitar qualquer implicação legal decorrente, sem deixar de aplicar as mesmas provisões para estes (ONU[h], 1955, p.292). Estes casos representam aproximadamente $1 \%$ do $\operatorname{total}^{23}$ e são publicados voluntariamente pelo Secretariado (OGANDAGA et al., 2009, p.16).

Todo mês o Secretariado publica o Montly Statement of Treaties and International Agreements $^{24}$ com a lista de todos os tratados e acordos internacionais registrados ou catalogados durante o mês precedente, junto de todas as informações de arquivamento associadas, listadas no primeiro parágrafo da presente sessão. Essa publicação separa os registros de novos tratados dos registros das ações subseqüentes referentes a tratados anteriores (ONU[d], 2006, p.34).

O Montly Statement não publica o texto (o conteúdo) de nenhum tratado, tarefa que fica a cargo do United Nations Treaty Series (UNTS). Esta última é sem dúvida a publicação mais importante em relação ao Artigo 102. Até 2010 foram publicados 2420

\footnotetext{
${ }^{23}$ Com base nos dados dos Suplementos do Repertório de Práticas dos Órgãos das Nações Unidas (ONU[h]).

${ }^{24} \mathrm{O}$ Monthly Statement of Treaties and International Agreements está disponível também online desde 1998 (acesso a esta publicação online em http://treaties.un.org/pages/MSDatabase.aspx).
} 
volumes do UNTS (ONU[h], 2010, p.4), totalizando mais de um milhão de páginas de tratados (incluindo suas repetições por traduções) (KOHONA, 2002, p.121). Os tratados podem ser submetidos em qualquer língua ${ }^{25}$, e são preparados para publicação com traduções em inglês e francês (e outras línguas quando isso for considerado necessário). $\mathrm{O}$ UNTS sempre inclui o texto em pelo menos essas duas línguas e na sua língua original (ONU[c], Artigo 12(1)).

Como a quantidade de documentos que deveriam ser preparados para publicação aumentou consideravelmente, o tempo entre o registro e a publicação também se tornou maior, chegando a 11 anos em 1997. O problema já vinha ocorrendo desde muito antes, e para contorná-lo em 1978 foi feita uma modificação nas Regulações instituindo a Política de Publicação Parcial ${ }^{26}$. Esta nova prática determina que os seguintes tratados bilaterais não sejam publicados na íntegra: a) acordos de assistência e cooperação de limitado escopo relativos a assuntos financeiros, comerciais, administrativos e técnicos; b) acordos relativos a organização de conferências, seminários e reuniões; c) acordos que serão publicados por extenso pelas agências especializadas (ONU[c], Artigo 12(2-4)). A Política de Publicação Parcial foi estendida para partes de certos acordos multilaterais (ex. lista de produtos) em 1997 (KOHONA, 2002, p.124). Se um documento cai dentro do escopo desta política ele ainda assim tem suas informações indexais publicadas em todas as outras publicações da ONU.

Parte das informações indexais dos tratados publicados é também incluída na publicação Treaty Series Cumulative Index, que é feita compilando as informações dos tratados publicados das últimas 50 edições do UNTS aproximadamente ${ }^{27}$.

Houve um esforço por parte do OLA a partir de 1995 no sentido de transformar as informações contidas no UNTS disponíveis na Internet através do United Nations Treaty Series Online Collection (KOHONA, 2002, p. 120). A base de dados formada por este esforço contem as informações indexais de cada tratado e a possibilidade de acessar o tratado completo tal qual publicado no UNTS.

\footnotetext{
${ }^{25}$ Há tratados em mais de 140 línguas distintas publicados pelo Secretariado (KOHONA, 2002, p.121).

${ }^{26}$ UN Doc. A/C.6/32/5/Add.1; A/52/363. Pela resolução A/RES/33/141 de 19 de dezembro de 1978.

${ }^{27}$ O banco de dados online desta publicação inicia-se no Volume 26 (1987-1988). (Acesso a base online: http://treaties.un.org/pages/CumulativeIndexes.aspx).
} 
O Secretariado é ainda o depositário de mais de 500 tratados multilaterais que tem sua própria publicação anual com as informações dos status de cada um deles, o Multilateral Treaties Deposited with the Secretary-General (AUST, 2005, p.112-113). Os tratados multilaterais tem também sua própria base de dados online que é atualizada diariamente $^{28}$.

\subsubsection{Definição do(s) assunto(s) e da lateralidade dos tratados}

Os tratados são classificados pelo Secretariado de acordo com sua lateralidade, podendo ser unilaterais, bilaterais, ou multilaterais.

Os tratados mais comuns no Banco de Dados da ONU são os bilaterais, definidos por serem feitos entre duas partes.

Os tratados multilaterais são aqueles que possuem mais de dois participantes, podendo ainda ser classificados em abertos ou fechados (dependendo se o número de participantes pode variar ou não). O Secretariado é o depositário de mais de 500 tratados multilaterais abertos. $\mathrm{O}$ banco de dados desses tratados está separado do banco de dados de todos os outros tratados, pois o Secretariado tem algumas obrigações a mais por ser o depositário, tal como manter atualizado o status de todos os seus participantes, bem como de comunicar às partes eventuais reservas ou mudanças.

Há ainda tratados considerados unilaterais, que são documentos feitos por um só ator, mas que são entendidos como gerando obrigações e deveres controlados pelo direito internacional. Exemplo de tratado unilateral é a aceitação da jurisdição compulsória da Corte de Justiça Internacional, ou a "Declaração do Canal de Suez" feita pelo Egito em 1957 (ONU[h], 1960, p.506; AUST, 2005, p. 111). Esse tipo de tratado é relativamente raro, mas seu registro junto ao Secretariado segue o mesmo procedimento.

Em algumas publicações (Monthly Statement) e na base de dados online é associado ao tratado um ou mais assunto referente. Por exemplo, ao tratado "Basic Agreement on cooperation in the Field of defense between the Argentine Republic and

\footnotetext{
28 A base de dados de tratados multilaterais pode ser acessada pelo site:
} http://treaties.un.org/pages/ParticipationStatus.aspx . 
Brazil" são associados os termos "Military Matters" e "Cooperation". Esses termos posteriormente servirão de variáveis manipuláveis pelas ferramentas aqui propostas.

\subsection{Atores internacionais}

O conjunto de Membros das Nações Unidas cresceu substancialmente ao longo dos mais de 60 anos de sua existência. Em 194551 Estados assinaram a Carta de fundação da organização, em 1970 já eram 127 Estados Membros, e atualmente (2012) são 193. Os tratados presentes no banco de dados em 1950 refletem as ações dos membros de então, conjunto bem diverso daquele que observaríamos se focássemos nos tratados presentes no mesmo banco de dados em 1980. O crescimento do número de Membros da ONU é a mais importante dentre as mudança no conjunto de atores, mudanças estas que afetam a formação do conjunto de dados analisado, e, portanto, sua representatividade, homogeneidade, confiabilidade e outras características. As representações visuais propostas serão baseada nestes atores, logo sua manipulação cuidadosa, incluindo uma descrição dos fatores influentes nas mudanças neste conjunto, deve ser feita; esta é a tarefa desta sessão.

\subsubsection{Critérios para filiação à $\mathrm{ONU}$.}

Somente Estados podem se tornar Membros da ONU, outras entidades podem ser parte da ONU com outro status. No entanto, no momento da formação da ONU foram admitidas como Membros fundadores entidades que dificilmente entenderíamos como sendo Estado soberano; este é o caso das repúblicas socialistas da Ucrânia e Bielorússia, que eram partes de uma Federação. Isso objetivou baixar a desconfiança da União Soviética com o projeto da ONU (CONFORTI, 2005, p.25). A Índia foi também admitida como Membro alguns dias depois, mesmo sendo parte não independente do Império Britânico (AUST, 2005, p.18, 205).

Normalmente se uma entidade é reconhecida pela comunidade internacional como Estado soberano, e necessariamente pelos membros permanentes do Conselho de Segurança, terá grandes chances de ter sua filiação à ONU aceita caso a petição seja feita ${ }^{29}$,

\footnotetext{
${ }^{29} \mathrm{O}$ processo pelo qual um Estado se filia a ONU envolve um pedido formal do Estado em questão que é analisado pelo Conselho de Segurança. É preciso que nove membros do Conselho votem a favor da admissão,
} 
pois esta mesma comunidade está representada na ONU. No entanto, há muitos casos em que a decisão sobre o reconhecimento de soberania é controverso ou disputado, o que se estende para a tentativa de filiação à ONU. O Chipre do Norte não teve apoio de quase nenhum governo para a sua declaração de independência de 1983; podemos imaginar que não teria apoio suficiente na Assembléia Geral para se filiar à ONU. A República da China (Taiwan) é reconhecida como soberana por alguns Estados, mas o fato de a República Popular da China ser membro permanente do conselho de Segurança impediu até o momento todas as tentativas de esta se filiar à ONU (14 vezes) Mais recentemente (2011) o Estado Palestino, que é reconhecido por mais de cem outros Estados, foi impedido pelo veto dos Estados Unidos, mantendo seu status na ONU de Observador Permanente.

Como já observado (sessão 3.2.3.), se um Membro pleno da ONU reconhece a soberania de um segundo Estado não-Membro e celebra tratados com ele, estes tratados serão catalogados normalmente pelo OLA (através do registro feito pelo primeiro). Aqui não importa que o status deste segundo Estado esteja em disputa, pois o secretariado não faz este julgamento. No entanto, o fato de este não ser membro da ONU evita que ele seja obrigado a submeter todos os seus tratados, o que afeta negativamente a representatividade do conjunto de tratados do país em questão.

\subsubsection{Evolução do número de Estados Membros da ONU e sua dispersão.}

As figuras a seguir (Figuras 3.4. e 3.5.) mostram a evolução do número de Estados Membros da ONU e sua dispersão geográfica. 
Figura 3.3. Aumento do número de Estados Membros da ONU, 1945-2011.

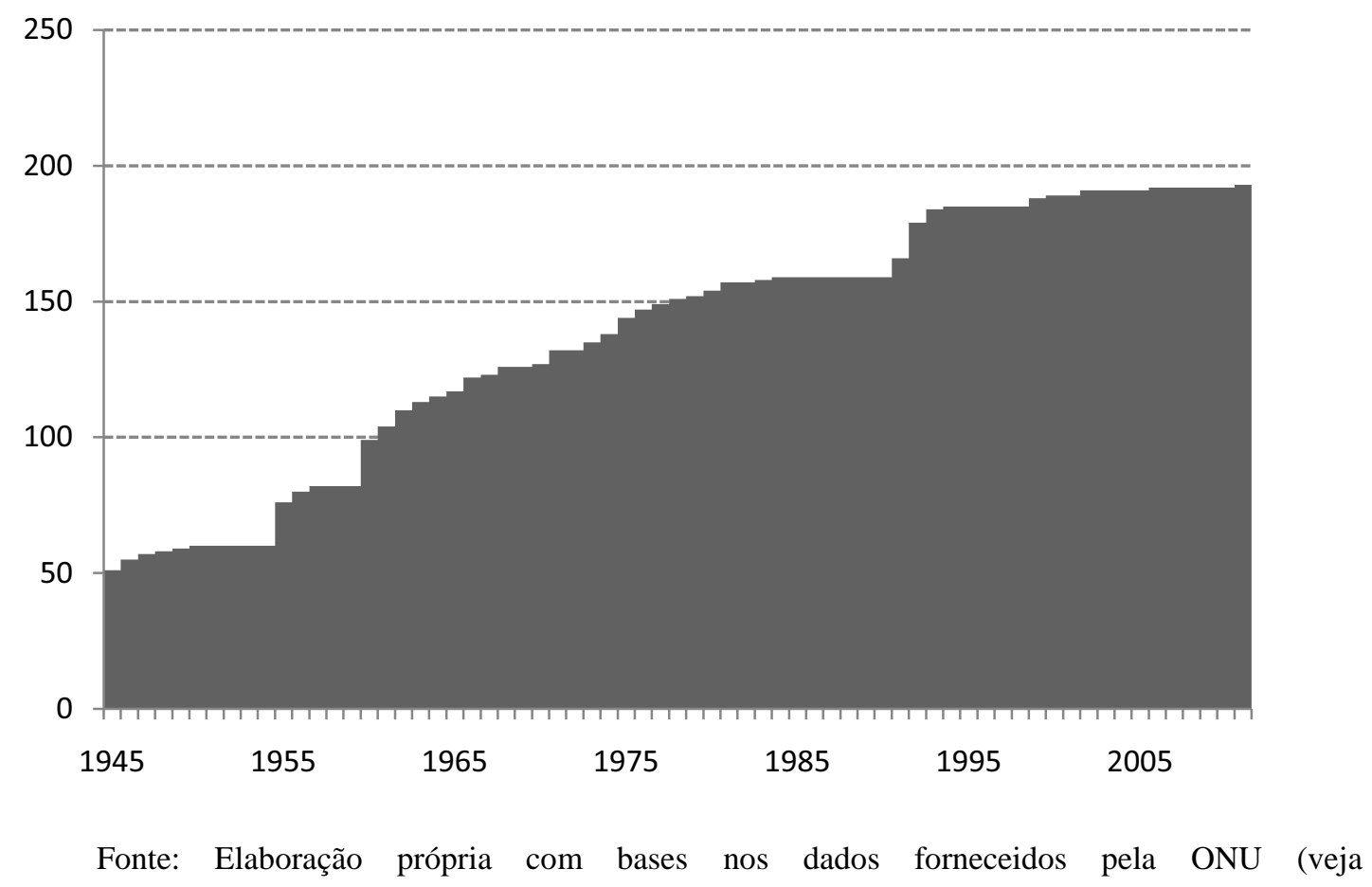
http://www.un.org/en/members/growth.shtml).

Podemos perceber três grandes degraus no gráfico (Figura 3.3.) (1955, 1960, 1991) que representam momentos em que o número de Estados Membros aumentou abruptamente. Entre os anos de 1946 e 1950 os Estados que postularam filiação à ONU foram aceitos sem dificuldade, mas após o início da guerra da Coréia em 1950 os países do bloco capitalista vetaram a entrada dos países do bloco soviético e vice-versa. Esse impasse foi dissolvido em 1955, o que levou à entrada quase simultânea de dezesseis novos países nesse ano (AUST, 2005, p. 206), criando o primeiro grande degrau visto no gráfico. O segundo grande degrau (1960), junto com o crescimento ao longo das duas décadas seguintes, decorre da entrada de novos membros que eram, na sua maioria, países recentemente independentes, especialmente os envolvidos no processo de descolonização africana. O degrau visto no início da década de 1990 reflete o processo de dissolução da URSS. Na década de 1990 foi aceito que micro-Nações poderiam se tornar Estado Membro da ONU, o que levou à admissão de países como Andorra, Mônaco, Tuvalu e Nauru (AUST, 2005, p.206). 


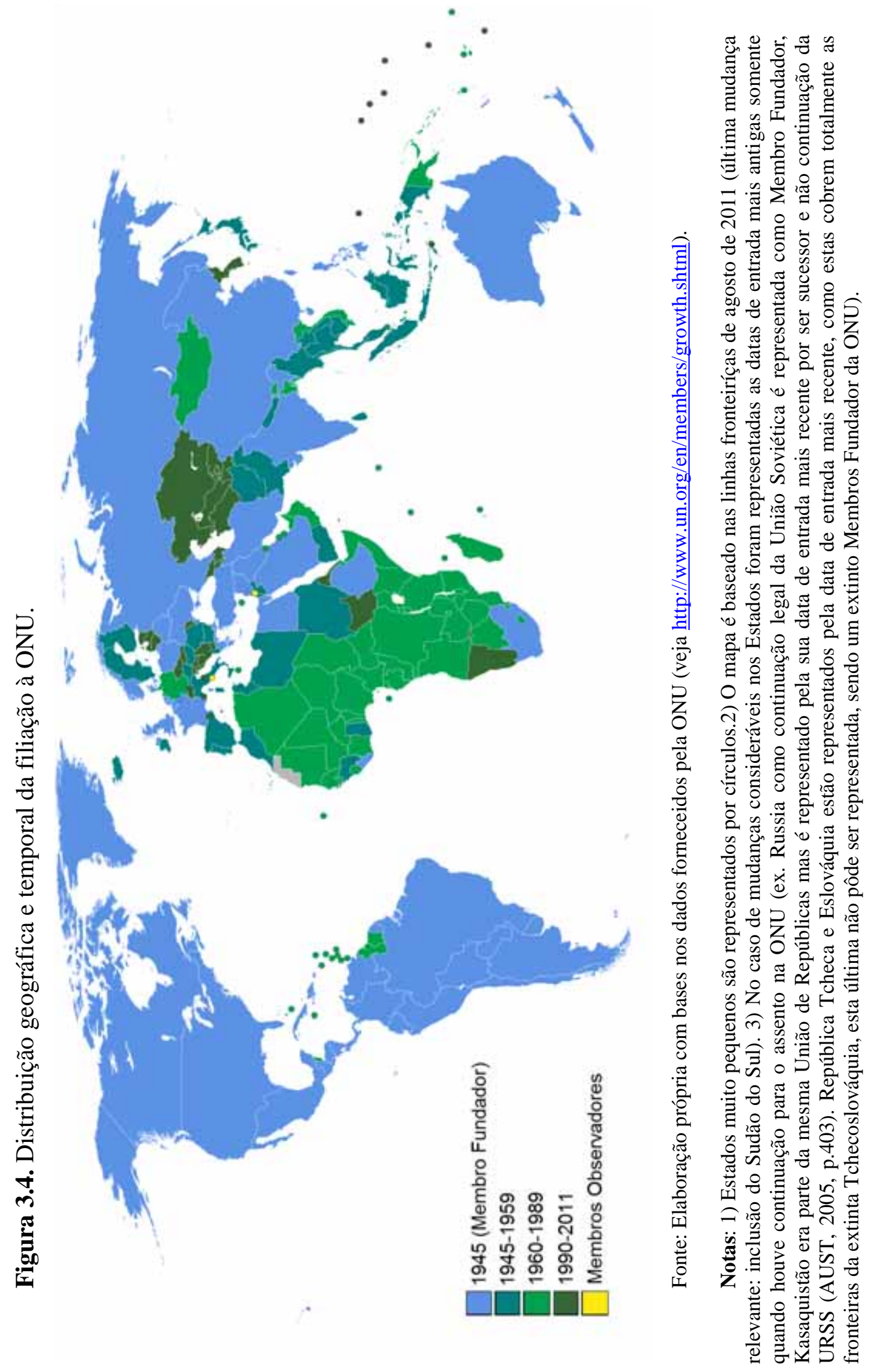


Observando o mapa percebemos que atualmente poucas áreas ficam fora daquela coberta pelo conjunto de Estados-Membros da $\mathrm{ONU}^{30}$. Percebemos também conjuntos de países com datas de entrada similares, refletindo os já mencionados grandes processos de descolonização e o de dissolução da URSS. Além destes processos gerais seria necessária, para explicar as datas de entrada de cada um das Nações na ONU, uma discussão histórica e política, o que não faremos por estar fora do objetivo desta sessão.

O gráfico e o mapa nos permitem perceber a complexidade do significado das mudanças no conjunto de Estados Membros representados no banco de dados analisado. $\mathrm{O}$ mundo da política internacional é sem dúvida bastante dinâmico, e, em particular, o conjunto de Estados Membros pertencentes ao banco de dados mostra seguir esta mesma tendência. A representatividade de um recorte dos dados que inclua somente a década de 1950 será distinta daquela feita com a década de 1990, mesmo que o recorte se restrinja somente aos países que fazem parte de ambos os sub-conjuntos, pois a possibilidade de fazerem tratados com terceiros será distinta. Isto implica na necessidade das ferramentas e do usuário lidarem com este dinamismo.

Assim a filiação à ONU e a possível saída desta são importantes para a pesquisa em questão, pois somente os Estados Membros são obrigados pela Carta a registrarem todos os tratados de que são parte e porque o conjunto inteiro se modifica quando um novo ator ingressa.

\subsubsection{Tipos de atores internacionais presentes no banco de dados}

Sem dúvida os Estados Membros da ONU são os atores internacionais mais bem representados no banco de dados analisado, pois somente eles são obrigados pela Carta a depositarem tratados e acordos internacionais do qual fazem parte junto ao Secretariado. Mas estes não são os únicos atores internacionais presentes neste banco de dados. Estados Membros podem fazer acordos com Estados não-Membros e registrar devidamente tais acordos, ou ainda Estado Membros podem celebrar acordos com Organizações

\footnotetext{
${ }^{30}$ A única área perceptível neste mapa não coberta por um Estado Membro da ONU atualmente é o Saara Ocidental, na costa noroeste africana, que é historicamente disputada pelo Marrocos e atualmente está sob jurisdição da ONU, que seguidamente adia o referendo sobre seu status (AUST, 2005, p.28). Outras áreas fora do âmbito da ONU muito pequenas para serem perceptíveis neste mapa também existem, bem como áreas com status ambíguo ou em disputa (Taiwan por exemplo é representado como parte da República Popular da China, tal qual reconhecido pela ONU, a Somalilândia como parte da Somália, a Palestina como Observador Permanente).
} 
Internacionais ou Organizações Sub-Nacionais que tenham o poder para tanto ${ }^{31}$. Assim o banco de dados contempla uma série maior de atores internacionais do que somente os Estados Membros, embora seja focado predominantemente nestes.

Estados não-Membros, quer sejam reconhecidos pela ampla maioria ou quer tenham o status de sua soberania em disputa, estão presentes no Banco de Dados sem distinção. A Suíça, um dos Estados mais antigos do mundo, só filiou-se à ONU no ano de 2002 (ONU[i]), mas está presente como parte de mais de 700 tratados bilaterais ${ }^{32}$ neste banco de dados até o ano de 2000. Isto se deve ao fato de que os atores com quem a Suíça celebrou tratados eram estes sim Estados Membros da ONU, logo estes sendo os responsáveis pelo registro desses tratados junto ao Secretariado. A República da China (Taiwan) por sua vez aparece somente 12 vezes depois de ser excluída da ONU entre 1972 a 1987.

As Organizações Internacionais (OI) cresceram em número e em importância ao longo do século XX. A Organização das Nações Unidas e suas agências especializadas são o maior exemplo disso. Estas têm, pelas Regulações, de registrar seus tratados exofficio no UNTC. Do mesmo modo, toda vez que um Estado Membro faz um tratado com uma OI, este é da mesma forma registrado. Assim, com o passar do tempo, mais de mil OIs se fazem presentes no banco de dados, algumas delas com quantidades de tratados surpreendentemente altos, tais como o Banco Internacional para Reconstrução e Desenvolvimento (BIRD) com mais de 5 mil tratados registrados até o ano de $2010^{33}$. Isto é aproximadamente a metade da quantidade de tratados celebrados pelos EUA, o maior ator em quantidade, no mesmo período. A maioria, no entanto, faz relativamente poucos tratados.

\footnotetext{
${ }^{31}$ Como vimos na sessão (3.2.7.) as Agências especializadas da ONU também submetem seus tratados ao OLA, e ainda Organizações Internacionais podem submeter seus tratados que serão também registrados em separado.

${ }^{32}$ Compilação própria baseados nos dados da UNTS. Nota-se que olhando para os dados fornecidos pelo World Treaty Index, temos mais de 1300 tratados deste ator até o anos de 2000, uma boa parcela de tratados feitos com não-Membros.

${ }^{33}$ Baseado nos dados do UNTS. Mais detalhes nas Figuras 4.1. e 4.5.
} 
Figura 3.5.. Quantidade de tratados bilaterais de A) Atores territoriais entre si; B) Atores territoriais e Organizações Internacionais; C) Organizações Internacionais entre si; 1945 - 2007.

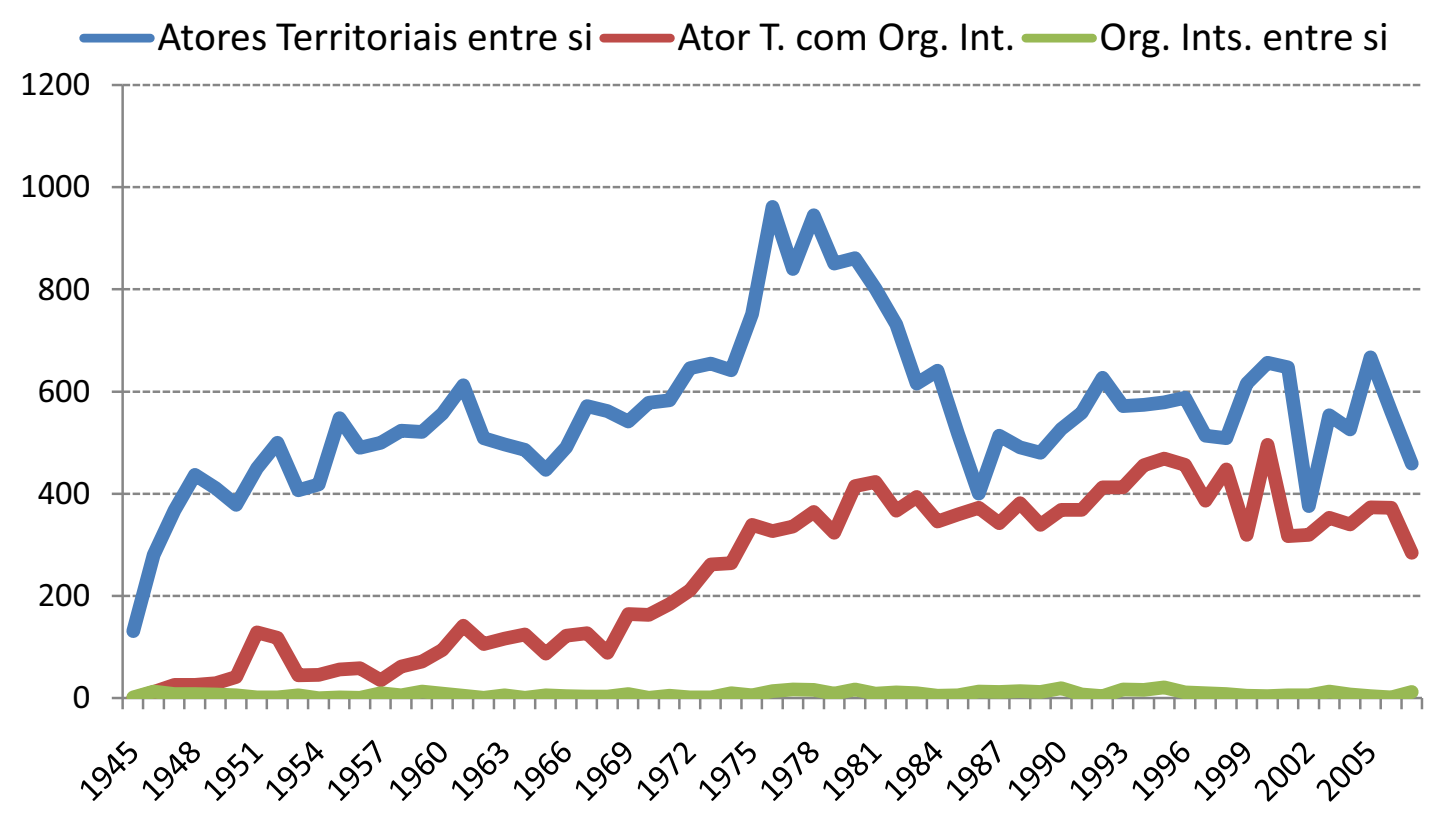

Fonte: Elaboração própria com base nos dados do UNTS.

A Figura 3.5., por sua vez, mostra a evolução da quantidade de tratados por tipo de atores presentes no conjunto: atores territoriais e Organizações Internacionais. Percebemos que de maneira geral as Organizações Internacionais apresentam crescimento que acompanha aquele dos atores territoriais até meados da década de 1970, a partir daí a participação das primeiras no total cresce.

As Organizações Sub-Nacionais são aquelas que têm o poder de celebrar tratados concedido pela constituição do órgão Nacional de qual fazem parte, sejam Estados ou Federações de Estados. Estes atores podem tomar distintas formas, tais como protetorados, enclaves, colônias, parte de uma Federação de Estados, ou mesmo ministérios ou empresas Estatais, tais como o BNDES para o Brasil. As Organizações Sub-Nacionais se diferenciam das Organizações Internacionais por faltar-lhe o caráter supranacional. Já discutimos a controvérsia sobre o poder de celebrar tratados destas organizações (sessão 3.2.3.). Seguindo a prática do Secretariado, se o Estado Membro entende que o ator com quem celebra um tratado tem o poder para tanto, com raras exceções, o registro do tratado é 
feito, deixando explícito que isso não confere às partes ou ao documento um status que estas, ou este, já não tivessem.

A classificação dos diferentes tipos de membros é importante para a ferramenta na medida em que esta é tanto uma informação que gostaríamos de ver representada quanto uma variável para manipulação destes dados. Pode interessar, por exemplo, utilizar o conjunto de dados com ou sem as Organizações Internacionais, ou selecionando um Estado e todas as Organizações Sub-nacionais a ele subordinadas.

\subsubsection{Mudanças no conjunto de atores relevantes para a representação} visual e a sucessão aos tratados

Ao fazer a análise dos tratados celebrados, por exemplo, pela França, seria interessante saber qual o governo que geria este Estado à época de um dado recorte, mas esta informação, por simplicidade, não foi escolhida para ser representada na ferramenta. Por outro lado se um Estado se tornou independente de outro, ou se dois Estados se fundiram formando um terceiro, ou ainda se um Estado se dividiu em dois, estes seriam acontecimentos relevantes para a construção das representações visuais da forma como propomos, pois os atores são representados como unidades constantes ao longo do tempo. Os atores internacionais presentes no banco de dados seguidamente sofrem mudanças, algumas destas alterações são relevantes para a construção da representação visual e outras são relevantes para uma análise desta representação visual. É necessário explicitar algumas das mais relevantes mudanças na condição dos atores que devem ser levadas em conta no momento da construção de uma representação visual que tenha por base estes atores e seus tratados. Essas mudanças são basicamente a entrada de novos membros no conjunto representado (pormenorizado nas sessões 3.3.1. e 3.3.2.), a fusão de membros, a divisão de membros e a extinção destes (ou saída da $\mathrm{ONU}^{34}$ ). Uma lista com as datas desses fatos para

\footnotetext{
${ }^{34}$ Se um Estado se retira da ONU deixa de ser obrigado pelo Artigo 102, e portanto o conjunto de tratados presentes não terá mais a mesma representatividade (somente estará representado indiretamente quando outros Estados registram tratados que celebraram com este). Há dois únicos exemplos em que um Estado Membro se retirou da ONU, nos dois a saída foi somente momentânea pois foram readmitidos posteriormente: a Indonésia que em 1965 deixou a ONU; e a Síria, que em 1958 unificou-se com o Egito deixando de ser Membro distinto (CONFORTI, 2005, p.38). Os dois Estados foram readmitidos como Membros desta através de um processo simplificado em 1961 para a Síria quando esta se separou do Egito e em 1966 para a Indonésia mediante seu desejo expresso. Durante estes hiatos a Síria não poderia realizar nenhum tratado (a não ser como subordinada ao novo Estado), e a Indonésia não foi obrigada pelo Artigo 102 a registrar os seus.
} 
os atores presentes no banco de dados é feita com relativa facilidade. No entanto, saber o que ocorre com os tratados ao longo de alguns destes casos é tarefa muito mais complicada.

Como vimos, quando um Estado celebra um tratado uma ligação de direitos e deveres se estabelece entre o tratado e o território desse Estado. Mesmo se um Estado mudar seu nome, constituição ou governo, por vias revolucionárias ou constitucionais, sua personalidade jurídica internacional não é afetada por estas circunstâncias, o que implica que este seguirá preso aos deveres e obrigações dos tratados dos quais é parte ${ }^{35}$ (AUST, 2005 , p.25, 390). Este princípio é seguido pela representação visual que mantém a mesma unidade representando o Estado ao longo do tempo, inobstante qualquer mudança que não afete a continuidade desta figura jurídica internacional. Quando isso ocorre dizemos que o Estado é a continuidade do anterior.

Quando outro Estado (que pode ser um novo Estado) se torna responsável pelas relações internacionais de toda ou parte do antigo território uma série de problemas pode surgir. Este processo é chamado de sucessão de Estados (AUST, 2002, p.305), e envolve a manutenção e a forma das responsabilidades do Estado sucessor para com os direitos e deveres do Estado sucedido (dívidas, tratados, filiação às Organizações Internacionais, etc.).

Quando mudanças ocorrem, tais como independência, separação, incorporação, dissolução, unificação, desmembramento e extinção de Estados, geram-se dúvidas sobre a continuidade ou sucessão dos Estados em questão e, mais especificamente, dúvidas sobre a sucessão ou não dos tratados.

Não há regras definidas para o que deve ocorrer quando um Estado é sucedido por outro, e a prática histórica dos Estados nesse tema também é bastante variada. Pelo lado da codificação normativa do direito internacional, a Convenção de Viena sobre a Sucessão aos Tratados de 1978 é a fonte mais acionada sobre o tema. No entanto, ela tem poucos participantes e só entrou em vigor em 1996 quando os ex-Membros da União Soviética a ratificaram (AUST, 2005, p.394). Assim não se pode assumir que ela represente o direito internacional consuetudinário na área. Em relação à sucessão dos tratados podemos dividir idealmente em duas visões sobre o tema: a que crê que o Estado Sucessor é responsável por

\footnotetext{
${ }^{35}$ O novo governo, se desejar, pode, é claro, em nome do Estado, e de acordo com as provisões de cada tratado, sair ou extinguir legalmente os tratados em questão.
} 
todos os tratados anteriormente aplicados sobre um território, e a opinião de que o novo Estado não é responsável por nenhum desses tratados. Ao longo do século $\mathrm{XX}$, quando mais de cem Estados se tornaram independentes, há exemplos históricos de ambas as correntes, e de muitos outros representantes de uma mescla destes. Assim é necessário olhar caso a caso para descobrir qual foi o procedimento de um dado Estado sobre a sucessão dos tratados do Estado anterior.

A Rússia se considerou (e foi considerada) a continuidade da personalidade internacional da União Soviética, mantendo seus tratados e o assento em Organizações Internacionais como o Conselho de Segurança na ONU, bem como todos os tratados desta, exceto nos casos em que não se aplicariam mais ao novo território (por perda de parte deste). Os novos Estados formados pela dissolução da União Soviética como o Cazaquistão não se consideraram a continuidade da antiga União, e como tal não sucederam a nenhum de seus tratados, a não ser aqueles referentes às fronteiras que mesmo nestes casos comumente se mantêm ${ }^{36}$. As Repúblicas Soviéticas da Bielorússia e da Ucrânia, antes figuras jurídicas internacionais autônomas somente por derivação de poder da URSS, foram sucedidas pelos Estados Independentes da Bielorússia e Ucrânia, exemplificando a sucessão de parte de um Estado, ou seja, sendo sucessoras dos tratados de uma parte de uma Federação. Já os países bálticos Estônia, Letônia e Lituânia, a partir de 1991, se consideraram libertos de mais de 50 anos de ocupação soviética, mas pragmaticamente acordaram a manutenção de alguns tratados da União Soviética e, além disso, consideraram como novamente em vigor parte dos tratados celebrados nas décadas de 1920 e 1930, após sua independência e antes da ocupação soviética (AUST, 2005, pp.398-399).

A transformação de dois ou mais países em um único pode ocorrer através da unificação ou da incorporação (também conhecida como absorção). No caso da unificação há uma mescla dos Estados anteriores, e na incorporação um Estado se expande para acolher o outro dentro de si. Costuma-se dizer que as Alemanhas se unificaram em 1990, mas do ponto de vista dos tratados o correto seria qualificar o processo como o de incorporação visto que virtualmente todos os tratados da Alemanha Oriental foram extintos e o território de aplicação de todos os tratados da Alemanha Ocidental foi expandido para

\footnotetext{
${ }^{36}$ Entende-se que alguns tipos especiais de tratados se mantêm válidos em qualquer caso, tais como os que versam sobre território, fronteiras e navegação de rios. Mas embora este princípio esteja bem estabelecido sua extensão é controversa (AUST, 2005, p.395)
} 
cobrir a totalidade do novo território (AUST, 2005, p.395). Um exemplo mais correto de unificação seria o processo ocorrido entre Iêmen do Norte e Iêmen do Sul ${ }^{37}$ em 1990, formando a atual República do Iêmen (AUST, 2005, p.392). Nesse caso os tratados de ambos os anteriores foram mantidos com algumas exceções.

Assim, de maneira geral, a sucessão ou não de tratados é acordada politicamente entre os Estados e as terceiras partes destes tratados, não havendo "sucessão automática" para aqueles que são considerados novos Estados, mas sim para aqueles que são considerados a continuidade do anterior.

\subsection{Procedimentos de transformação dos dados.}

Nas sessões iniciais deste capítulo procuramos dar base para o trabalho de construir uma ferramenta de representação do conjunto de tratados ao descrever os pormenores da construção do banco de dados sob tutela da ONU e a dinamicidade dos atores envolvidos. Essa descrição tem o objetivo de tornar explícitos os fatores que influenciarão a construção do banco de dados paralelo e sua posterior representação, fatores estes que possivelmente limitam a confiança na utilização da ferramenta. Se tomarmos como exemplo uma representação visual dos tratados do Brasil da década de 1970, os dados representados refletirão um entendimento do que significa o termo tratado, refletirão as regras para registro da ONU, refletirão os critérios de codificação dos tratados em temas, refletirão o fato de o Brasil ser Membro da ONU nesta época, e refletirão os atores presentes no sistema. Se pudermos explicitar todos os fatores relevantes na formação dos dados e da representação, poderemos saber qual a real capacidade e confiabilidade da ferramenta de representar os processos políticos que queremos colocar em evidência.

De acordo com as características descritas para os tratados e para os atores presentes no banco de dados da OLA, e de acordo com as necessidades da ferramenta de visualização apresentada no último capítulo, construímos um banco de dados paralelo. É importante enfatizar que o banco de dados criado para ser manipulado pela ferramenta de visualização é distinto do banco de dados criado pelo Secretariado da ONU. O banco de dados paralelo é baseado quase que exclusivamente no banco de dados da ONU, mas

\footnotetext{
${ }^{37}$ República Democrática Popular do Iêmen (conhecido como Iêmen do Sul), e República Árabe do Iêmen (conhecido como Iêmen do Norte).
} 
contém conjunto de informações distintas, normalmente uma seleção específica do segundo, que são, quando necessário, transformadas e organizadas de acordo com as necessidades da visualização. Esta sessão tem justamente o objetivo de descrever as diferenças entre as duas, bem como os procedimentos usados para criar o banco de dados paralelo baseado em informações do banco de dados da ONU.

\subsubsection{Compilação de tratados}

Mantivemos a maioria das informações indexais de cada tratado na compilação do UNTC. São elas: a) datas de assinatura, ratificação, entrada em vigor e término; b) lateralidade; c) atores participantes; d) assunto(s) relativo ao tratado; e) informações indexais (nome do tratado, volume e página da publicação no UNTS).

Datas: a data mais importante é sem dúvida a de entrada em vigor, que é critério para registro dos tratados ${ }^{38}$. Assim, exceto por motivos de erro, todos os tratados tem pelo menos esta data, a data de registro e a data de assinatura, que por vezes é a mesma de entrada em vigor. Quando aplicável a data de ratificação também é adicionada. A data de extinção do tratado é mais difícil de ser localizada e organizada, pois é registrada como uma ação subseqüente àquele tratado, sendo necessário que se faça uma pesquisa entre todas as ações subseqüentes para encontrar as extinções e manualmente ligar estas aos tratados referentes.

Nos casos de erros e omissões ${ }^{39}$ aplicamos o seguinte procedimento: fizemos uma média para cada ano da distância entre o período de entrada em vigor e de registro e aplicamos para estes casos. A média foi feita tomando três anos antes e três anos depois do ano base.

Lateralidade: os tratados mantêm a lateralidade dada pelo UNTC: multilaterais e bilaterais. Excluímos do nosso banco de dados os tratados unilaterais, pela dificuldade de representá-los nas ferramentas propostas e por serem em número estatisticamente irrelevante. Os dados multilaterais foram usados somente na ferramenta geradora de relatórios, onde pode-se comparar a quantidade de tratados multilaterais por ator com a quantidade de bilaterais por estarem representadas no mesmo gráfico.

\footnotetext{
${ }^{38}$ Como visto, com exceção dos tratados multilaterais que tem o Secretariado como depositário.

39 Estes representam aproximadamente menos de $5 \%$ dos casos, ou seja casos onde não haviam informações sobre uma das datas ou estas estavam incompletas.
} 
Participantes: todo tratado com ao menos dois participantes no banco de dados da ONU são compilados da mesma maneira para o banco de dados paralelo. Uma lista histórica de participantes foi criada contendo as mudanças dentro deste conjunto de atores (veja detalhes na sessão 3.2). A lista de todos os atores presentes nos bancos de dados utilizados são dadas nos Anexos I e III, que trazem também a quantidade total de tratados de cada um deles.

Assunto: a coleção online oferece para cada tratado um ou mais assuntos relativos cuja lista está disponível no Anexo II, que mostra também as quantidades de tratados para cada tópico. Os dados do World Treaty Index também relaciona cada tratado com um assunto, isto é feito com critérios disponíveis publicamente e estão descritas no Anexo IV. Nota-se que esta compilação somente adiciona um assunto por tratado o que pode ser muitas vezes problemático visto que muitos tratados podem ser relacionados a mais de um assunto com facilidade.

Informações Indexais: O nome do tratado, as referências de volume e página da publicação do tratado no UNTS, a data de registro, o código dado ao tratado pela OLA.

\subsubsection{Compilação de atores}

Os atores são diferenciados conforme seu tipo: Estados Nação Membros da ONU, Estados não-Membros da ONU, Organizações Internacionais, Organizações Subnacionais. O critério para fazer esta organização é simples, seguindo a lista de Estados Membros da ONU, de não-membros, e separando, com base em diversas fontes, as Organizações Internacionais conforme seu caráter supra-nacional ou sub-nacional. As Organizações Internacionais foram ainda divididas em dois grupos, as que tinham um caráter universalista e aquelas que tinham um caráter regionalista. Em outras palavras, entre aquelas que por sua definição teoricamente aceitariam qualquer Estado como membro e aquelas que por definição têm uma amplitude possível de Estados como membros (ex: União Africana).

As datas de entrada na ONU são marcadas para os Estados Membros e com elas a ferramenta representa através de diferentes cores e transparências seu pertencimento ou não em dado período. Por exemplo, se no uso da ferramenta radial o usuário escolhe representar os tratados da década de 1950, os países que não existiam como entidades 
soberanas nesta época, ou seja, os que não poderiam fazer tratados, serão destacadas. Isso não impede que estes atores sejam parte de tratados e que sejam representados nas ferramentas, somente faz a distinção daqueles que são obrigados ou não pelo Artigo 102 da Carta.

Por meio das categorias usadas pelo United Nations Statistical Division os Estados Membros são agrupados em continentes. Vale lembrar que desta maneira as colônias e protetorados manterão sua localização geográfica na ferramenta radial, por exemplo, Angola, mesmo enquanto colônia ultramarina de Portugal, e cujos tratados são feitos sob os auspícios deste, estará representado no continente africano. Os mapas gerados serão montados de acordo com as fronteiras atuais, neste caso se o tratados for registrado como angolano no UNTS será representado no mapa de Angola sem distinguir se este foi feito sob soberania portuguesa antes de 1975. 


\section{CAPÍTULO 4. Análise Experimental e Conclusão.}

Neste último capítulo buscaremos em primeiro lugar apresentar exemplos de análises exploratórias feitas com base nas ferramentas propostas, focando em alguns casos particulares para mostrar as possibilidades de uma análise mais aprofundada partindo das ferramentas aqui propostas. Por último, a título de conclusão, voltamos a dialogar com as possibilidades e limitações das ferramentas propostas.

Retomando o que já foi discutido na introdução, o objetivo central das ferramentas é permitir a exploração dos dados. Como vimos as visualizações apoiadas por computador são bastante apropriadas para esta tarefa, especialmente para casos como este onde a quantidade e complexidade dos dados é grande. A exploração se dá tanto na manipulação das variáveis que elencamos para cada tratados, quanto na apreensão das diferentes representações visuais especializadas na expressão de diferentes dimensões do conjunto de dados.

Podemos ver dois caminhos de uso exploratório feito por meio da manipulação das ferramentas. O primeiro é partir de algo conhecido do usuário sobre a política internacional e utilizar as ferramentas para ver se e como este conhecimento é refletido nos padrões de tratado. Por exemplo, é quase senso comum entre os estudiosos de Relações Internacionais que durante a Guerra Fria o mundo da política internacional se dividiu em dois blocos, e é de se esperar que os tratados reflitam de alguma forma este entendimento. O usuário pode manipular e representar os dados para ter contato com as estruturas, padrões, características e mudanças neste âmbito. Com isso, este entendimento geral pode ser qualificado e aprimorado, por exemplo percebendo como esta ideia geral se apresenta em diferentes períodos e se há atores centrais para cada um dos grupos. O segundo caminho tem como ponto de partida a própria ferramenta. Isso ocorre quando a ferramenta gera uma questão que não tem apoio imediato no entendimento prévio do usuário sobre as Relações Internacionais. Isso pode acontecer por dois motivos: ou o usuário não tem conhecimento sobre o que está observando (por exemplo, se este é o primeiro contato com as relações exteriores da seleção feita), ou quando a representação contraria o entendimento anterior do usuário. Vale notar que o segundo caminho pode surgir a partir do primeiro. 
Devido às complicações na realidade política que baseia qualquer tratado, na compilação dos dados, e na representação visual destes, o resultado final pode ou não ser um reflexo das relações políticas nos padrões de tratados. Isto é, muitas vezes não saberemos dizer se os motivos para a representação final ter tais e tais características são encontrados em problemas em alguns dos passos de sua construção, ou se refletem genuinamente as relações políticas internacionais. Em muitos casos, que exemplificaremos abaixo, fica difícil crer que os padrões são aleatórios ou que não haja ligação entre um e outro $^{40}$.

Não esmiuçaremos exemplos em que a representação mostra algo contraintuitivo, algo que estivesse distante do que se esperaria como normal. Isso não será feito pois exemplos assim seriam menos seguros pelos motivos apresentados no parágrafo anterior e, como já foi frisado, o objetivo deste projeto nunca foi primordialmente o de fazer a análise dos padrões de tratados mas sim permitir que estas fossem feitas, e balizar sua qualidade. Escolhemos nos aprofundar em exemplos de análises firmadas em terrenos mais seguros para dar uma ideia geral das possibilidades das ferramentas e para testá-las. Mesmo assim há exemplos não aprofundados no corpo do texto e muitos outros atingíveis pela manipulação das ferramentas para os quais não sabemos os motivos causadores de suas características e cuja avaliação e análise ainda esperam seu feitor diligente.

\subsection{Alguns exemplos de uso das ferramentas}

Nestas duas primeiras sessões gostaríamos de mostrar exemplos de uso da ferramenta. Retomando o foco principal da ferramenta, isto é, permitir a exploração dos dados, escolhemos aquelas representações que entendemos fazerem jus a este foco. No entanto as ferramentas provêem possibilidades amplas de manipulação, o que, aliado a uma base de dados também extensa, possibilita criar uma quantidade de representações visuais enorme. Seria possível, seguindo este pensamento, criar um atlas com gráficos para cada ator, ou para cada assunto relativo aos tratados, dividido em diferentes recortes temporais. Como este não é o objetivo aqui, é preciso escolher algumas seleções entre as possíveis

\footnotetext{
${ }^{40}$ No entanto se tomássemos um desses casos e se porventura o padrão fosse muito distinto do esperado o observador talvez facilmente descartasse a representação por ser contra-intuitiva, possivelmente assumindo algum erro em algum ponto do longo processo de criação desta. Mas e se esta hipótese contra-intuitiva representasse justamente algo relevante que o observador ignorava? Neste caso ele perderia o maior ganho analítico que a ferramenta poderia dar para este caso.
} 
para exemplificar como as ferramentas podem ser usadas produtivamente. O método de escolha destes exemplos tem como critério apenas tentar ser representativo das possibilidades das ferramentas e dos dados que estas manipulam. Esperamos que os exemplos escolhidos sejam também interessantes para a disciplina, embora este seja um critério subjetivo.

As ferramentas estão aptas a serem manipuladas por meio de algumas variáveis, em especial datas, atores e assuntos relacionados. As disposições visuais voltam-se especialmente para três tipos de análises: a) temporais (quantidades de tratados da seleção ao longo do tempo); b) espaciais (distribuição das quantidades de tratados da seleção) e c) comparativas, isto é, comparações de composição entre seleções (especialmente de assuntos e atores com quem se fazem os tratados). Com isso permite-se que o usuário tenha contato com as características subjacentes ao conjunto de dados selecionado. Iniciaremos com exemplos de análises focadas nos atores, e posteriormente nos assuntos relacionados aos tratados, mostrando para cada um deles exemplos de análises temporais, espaciais e comparativas. 


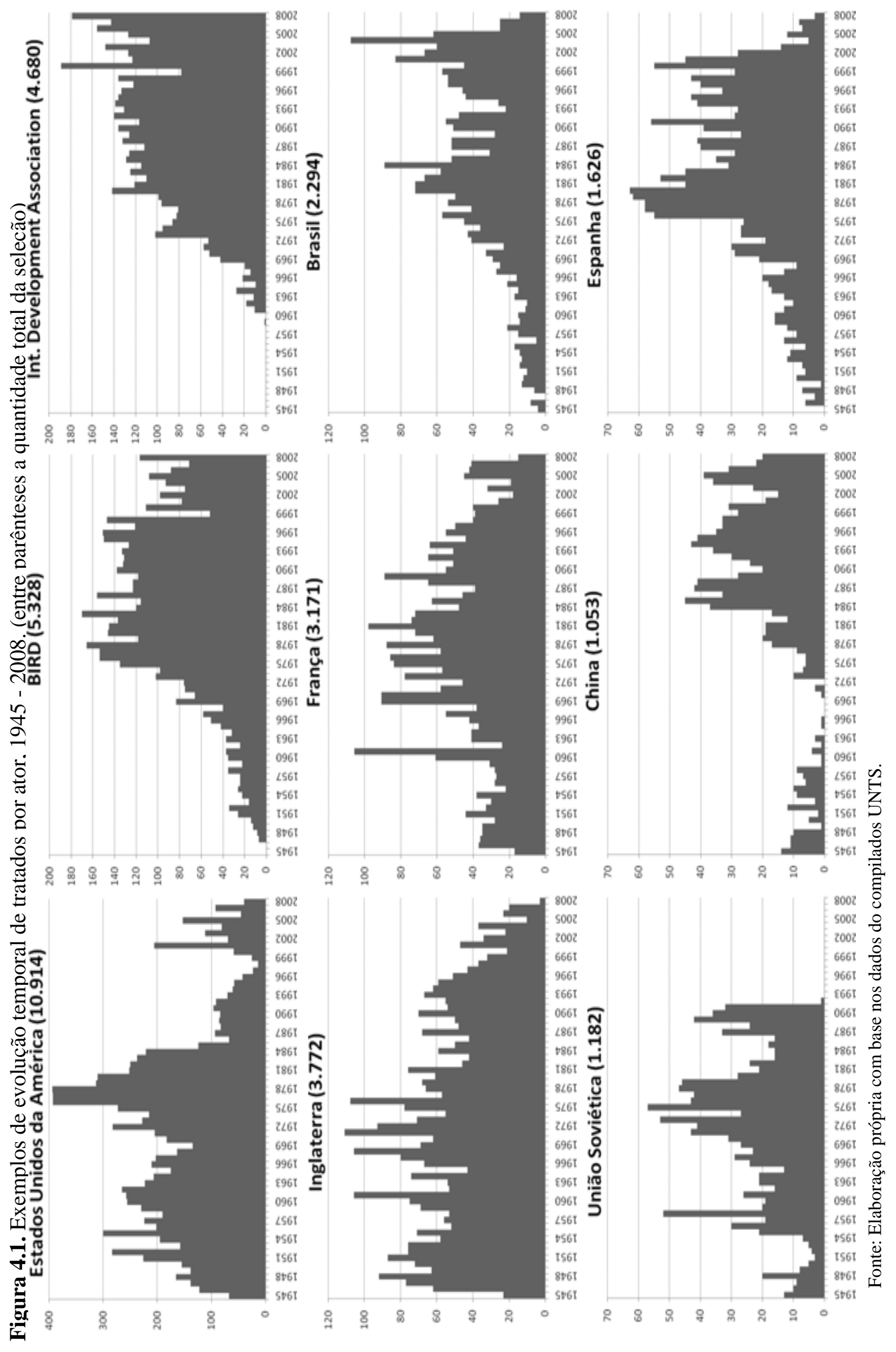




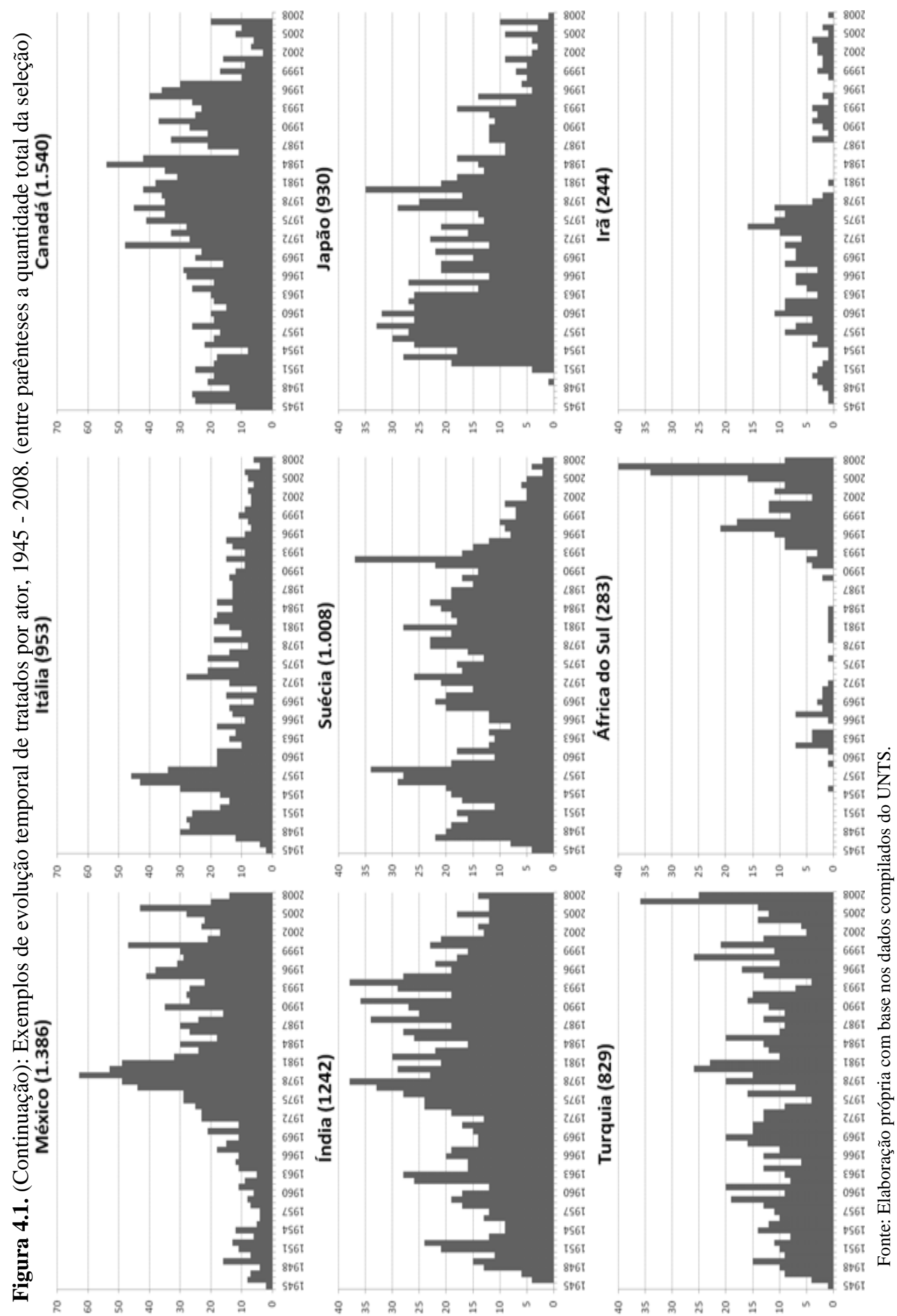

$\approx$ 
As duas páginas anteriores trazem exemplos da evolução da quantidade de tratados bilaterais de uma série de atores internacionais presentes no banco de dados da ONU.

Olhando para cada um destes gráficos mais detidamente podemos ter uma rápida idéia, o que até então não era possível sem esta ferramenta, da distribuição ao longo dos últimos 65 anos da quantidade de tratados registrados na ONU de cada um dos atores selecionados. Este primeiro olhar já instiga o observador à interpretação, por exemplo, quando se procuram os motivos para os padrões observados, entendendo que os dados estão provavelmente refletindo os acontecimentos políticos do mundo real. Para algumas afirmações simples podemos intuir o motivo. O fim da União Soviética, por exemplo, é aparente no seu gráfico a partir do inicio da década de 1990. Ou o caso chinês, em que se percebe que a partir de 1971 (quando o governo comunista foi reconhecido na ONU) há uma retomada nos tratados deste ator. No caso das duas grandes agências do Banco Mundial, O BIRD e o IDA (International Development Association), podemos ver o momento de ascensão destas (o BIRD foi criado em 1945 e o IDA em 1960). Pode ser interessante também comparar um gráfico com outros, atentando que a escala de cada um deles pode ser diferente.

Em outros casos as representações visuais geram somente perguntas sobre os motivos para os padrões vistos. Podemos ver em que época se concentram as quantidades de tratados para cada ator, e qual a tendência ao longo do período selecionado. Observando as escalas dos gráficos, os Estados Unidos apresentam a maior quantidade de tratados entre todos os atores, mas estes claramente se concentram entre 1950 e 1980 . Haveria motivos políticos para os picos presentes nos gráficos representando os tratados em que o Brasil é parte? Como explicar a evolução observada para os tratados em que a Espanha é parte?

A depender do conhecimento prévio do analista a interpretação e mesmo as perguntas geradas serão distintas. Alguém com bastante conhecimento ou interesse nas relações internacionais francesas provavelmente terá opiniões distintas para oferecer à interpretação dos dados franceses do que alguém sem conhecimento nenhum desta. É esperado que na maioria dos casos as representações sirvam para gerar perguntas ou hipóteses que somente podem ser respondidas (quando puderem ser respondidas) com aprofundamento em outras fontes. 
Um dos gráficos que mais chama a atenção é o dos Estados Unidos, mostrando uma queda acentuada na quantidade de tratados registrados no UNTS ao longo do período. O gráfico a seguir deixa isso ainda mais claro, ao comparar o país com o total de todos os países exceto ele mesmo. Os Estados Unidos são de longe o ator com maior quantidade de tratados no banco de dados como um todo, e como se pode ver, chegou a ser responsável por quase metade de todos os tratados registrados. A participação americana no total vem, ao longo deste extenso período, oscilando com tendência a queda.

Figura 4.2. Quantidade de tratados bilaterais americanos, do mundo e porcentagem dos EUA no total mundial, 1945-2007.

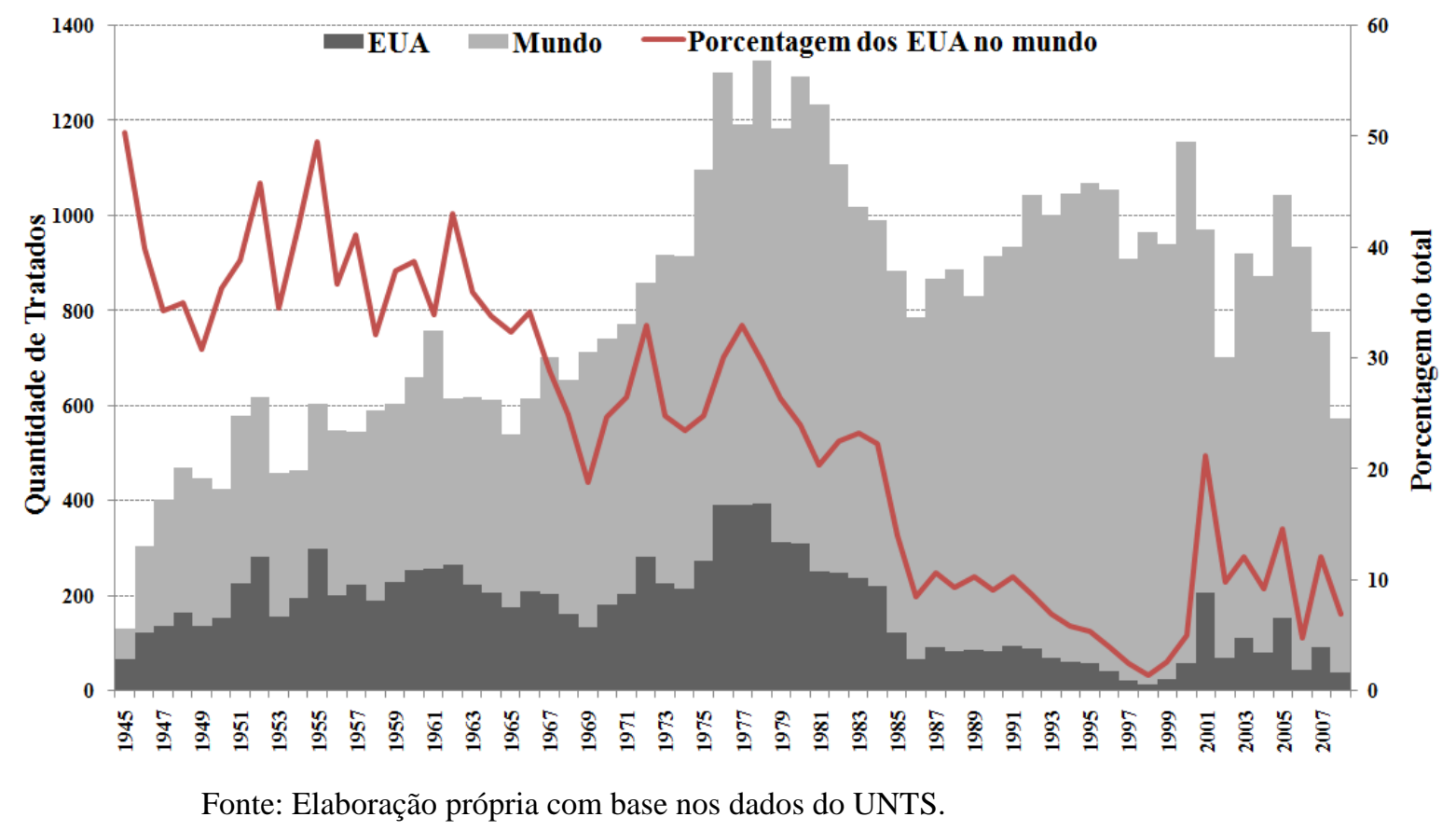

Mas estes gráficos temporais ainda escondem algumas nuances que podem ser trazidos à luz pela manipulação das outras representações possibilitadas pelas ferramentas. Podemos esmiuçar geograficamente os dados presentes em qualquer uma das seleções para tentar analisar como se distribuem ou concentram espacialmente uma dada seleção de tratados. Como explicitado na sessão 2.2.1. as soluções apresentadas neste sentido envolvem a construção de mapas e visualizações radiais. A primeira, apesar de ser mais intuitiva, sofre por não ser apta a representar atores não territoriais. Vejamos alguns exemplos de distribuição espacial nas figuras a seguir. 
Figura 4.3. Distribuição espacial dos tratados Argentina, 1945-2008.

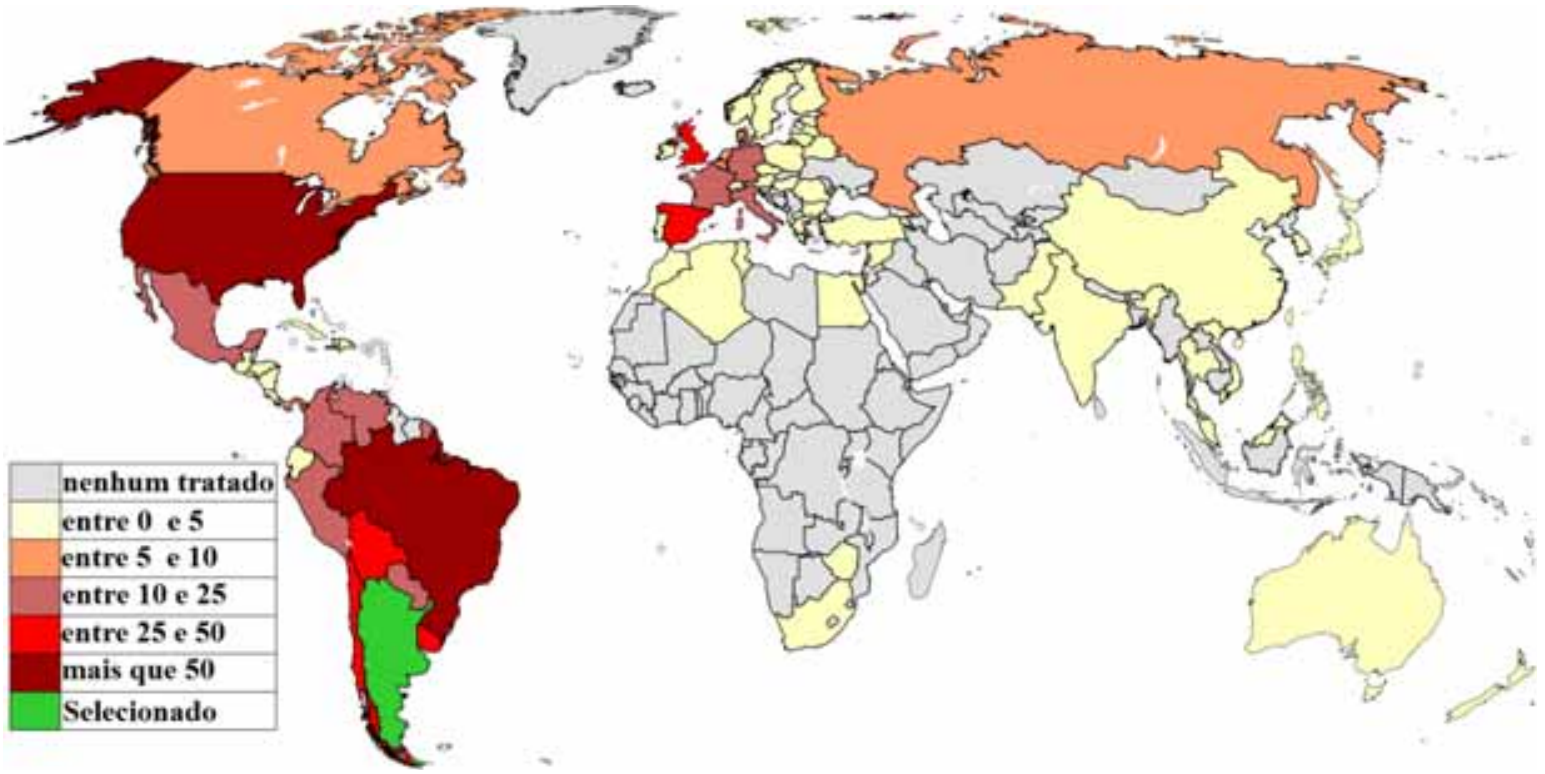

Fonte: Elaboração própria com base nos dados compilados do UNTS.

Figura 4.4. Distribuição espacial dos tratados da China, 1945-2008.

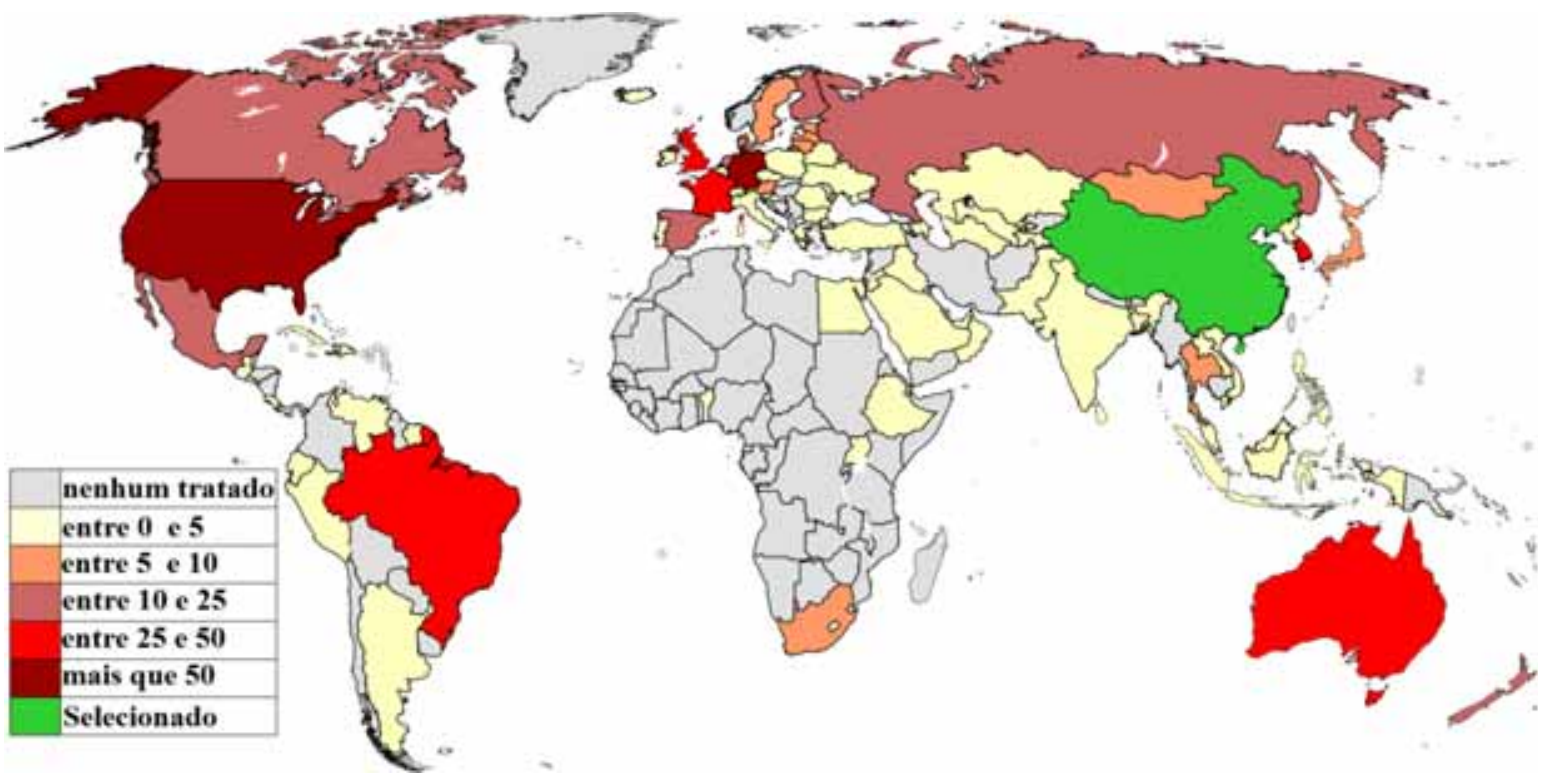

Fonte: Elaboração própria com base nos dados compilados do UNTS. 
Figura 4.5. Distribuição espacial dos tratados do BIRD, 1945-2008.

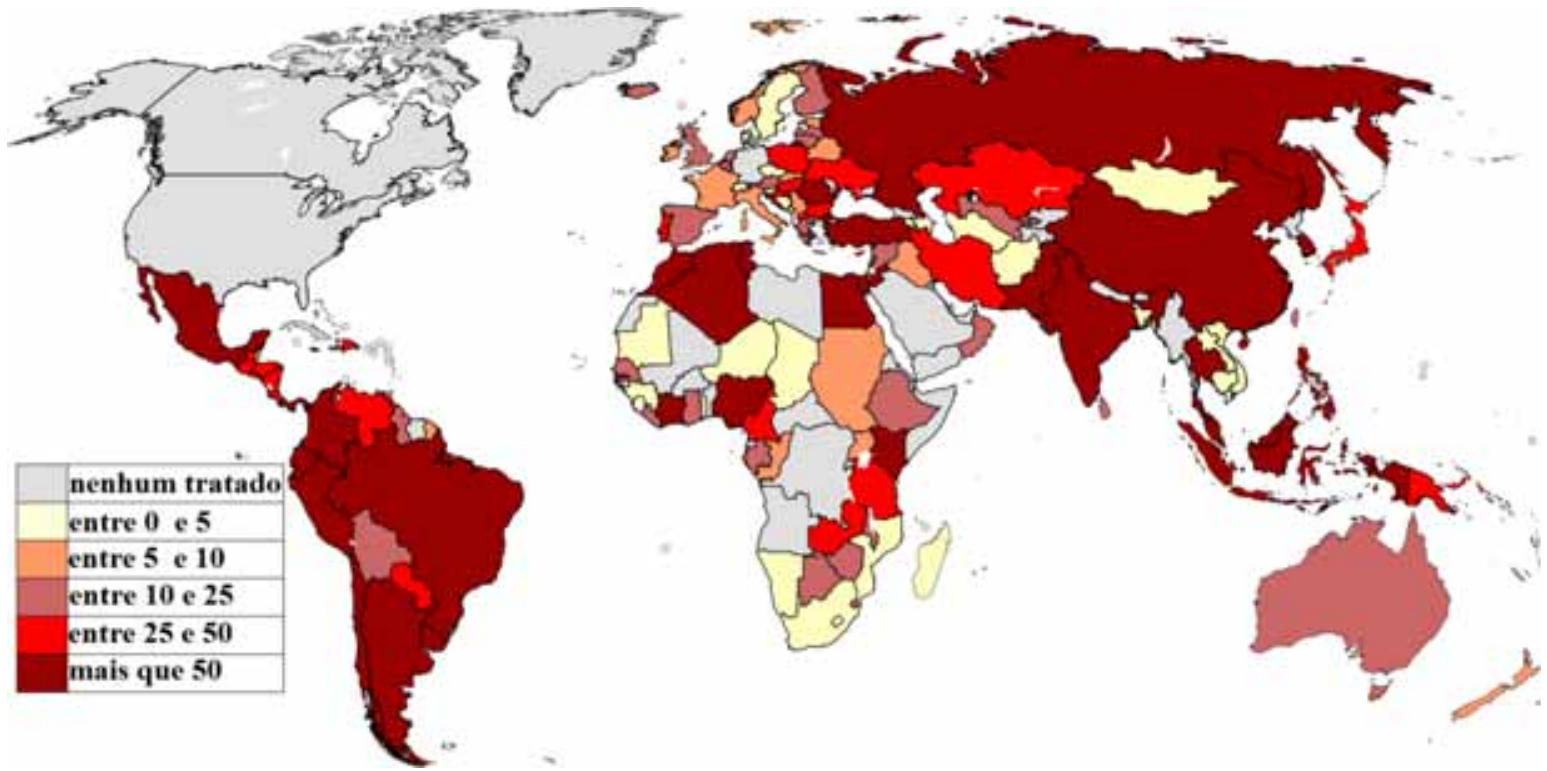

Fonte: Elaboração própria com base nos dados compilados do UNTS.

Figura 4.6. Distribuição espacial dos tratados da IDA, 1945-2008.

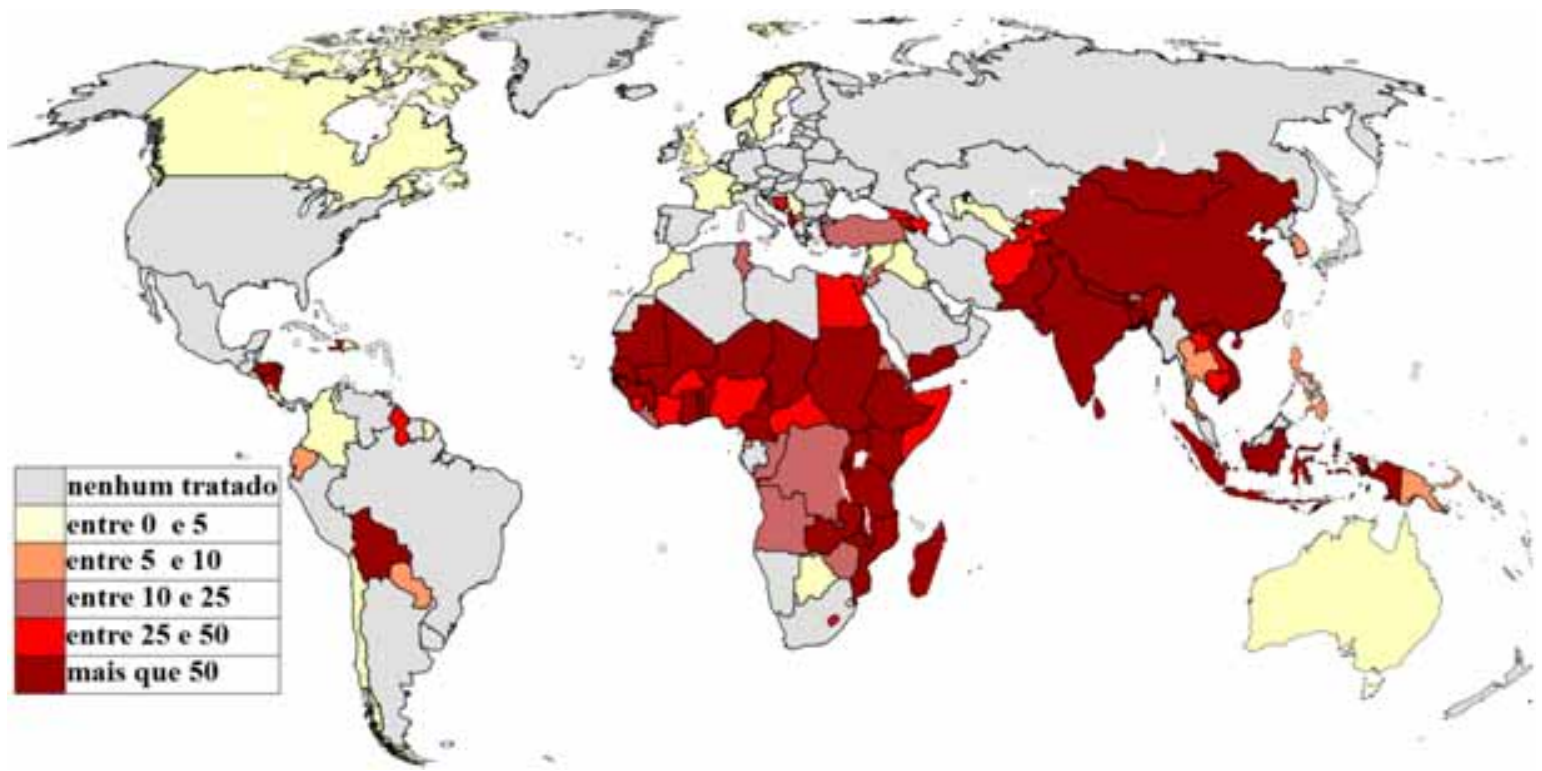

Fonte: Elaboração própria com base nos dados compilados do UNTS. 
Figura 4.7. Distribuição espacial dos tratados da URSS, 1945-1991.

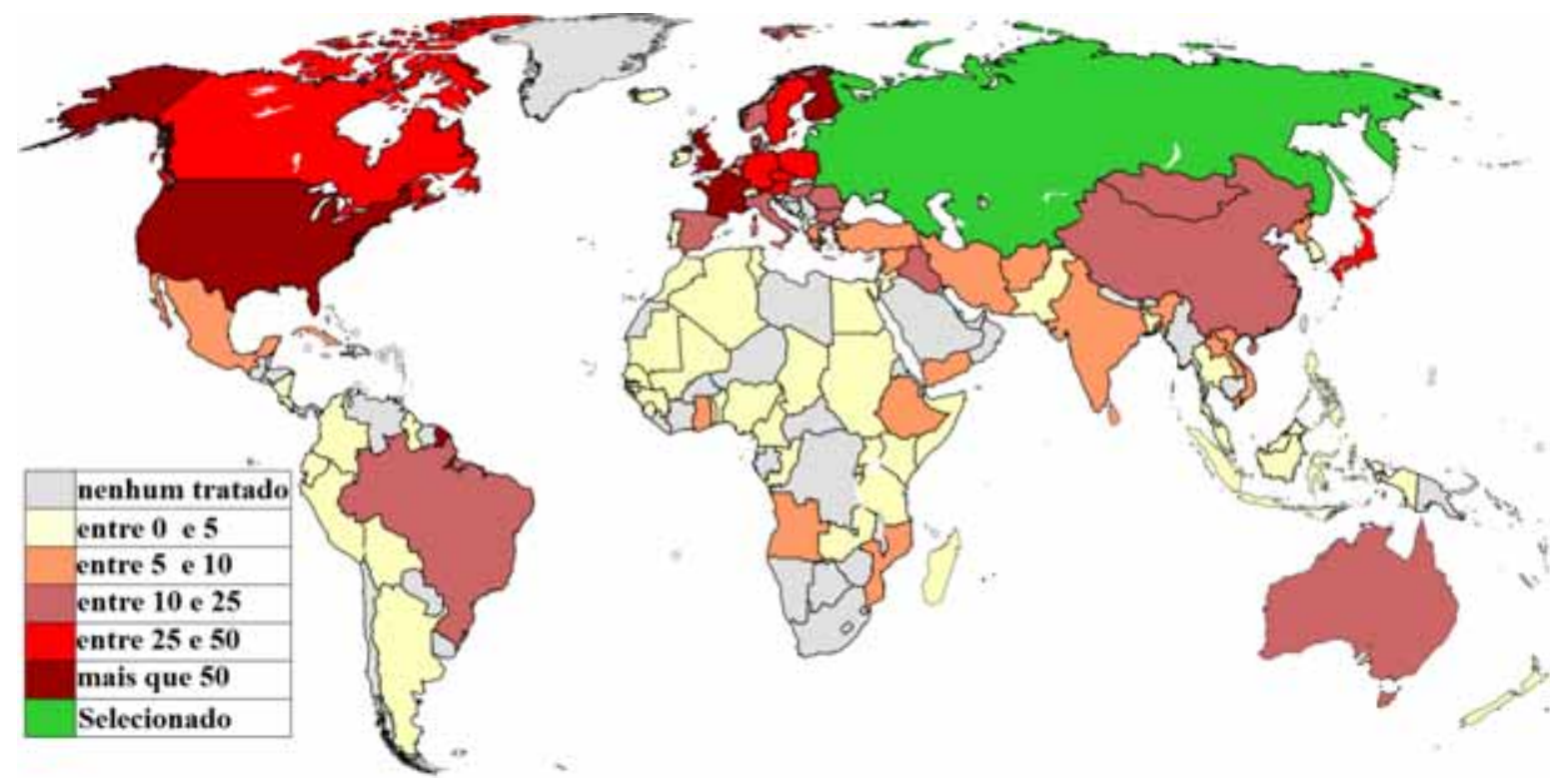

Fonte: Elaboração própria com base nos dados compilados do UNTS.

Os mapas possibilitam ver os padrões da distribuição dos tratados, espacialmente e quantitativamente. Ao compararmos, por exemplo, os dois mapas que representam a distribuição de tratados de Organizações Internacionais (Figuras 4.5. e 4.6.) percebe-se que a IDA concentra seus tratados nos países africanos centrais e no sudeste asiático, enquanto que os tratados feitos pelo BIRD, menos concentrados, são expressivos na América Latina, leste europeu e sudeste asiático. Esta distribuição está condizente com os desígnios do Banco Mundial para estas agências, com foco em faixas de países distintos pelo grau de desenvolvimento. Vale lembrar que a grande maioria dos tratados de ambas estas agências são relacionados a empréstimos, mas nem todo empréstimo se dá com a necessidade de um tratado; isso ocorre usualmente quando há necessidade de garantias dadas pela entidade soberana.

Em comum a todos os outros mapas que não das Organizações Internacionais percebe-se tendência de concentração de tratados primeiro com as grandes potências e em segundo lugar com os países vizinhos ou próximos. O caso da Argentina, por exemplo, demonstra concentração de tratados na América do Sul.

Se usarmos vários mapas com seleções temporais distintas, o que é permitido ao usuário, podemos fazer comparação entre a distribuição espacial de um mesmo ator ou 
de um mesmo assunto ao longo do tempo. Esta opção será exemplificada com base no Brasil posteriormente neste capítulo.

As ferramentas permitem, assim, que depois de um primeiro contato com os padrões da seleção através de manipulações o observador possa aprofundar seu entendimento das características escondidas. Olhando para a distribuição temporal dos dados perguntas surgem, representando os mesmos dados de modos distintos, elencando uma de suas dimensões, podemos qualificar estas dúvidas, gerar novas perguntas, ou até mesmo nos aproximar de respostas. Se percebermos um pico na quantidade de tratados de um ator podemos explorar este período, descobrindo com quem estes tratados são feitos, se estão concentrados ou dispersos espacialmente, quais são os assuntos que predominam relacionados aos tratados em questão e qual é a evolução destes assuntos.

Se o observador tem maior interesse em ver a distribuição dos tratados não de um ator mas sim de um ou mais assuntos, é possível utilizar procedimentos semelhantes aos já demonstrados para este conjunto de dados. A Figura 4.8., na próxima página, traz alguns exemplos de representações temporais para alguns assuntos.

Como vimos, os assuntos foram associados a cada tratado pela ONU e vale lembrar que mais de um assunto pode ser associado a cada tratado (ver sessão 3.4.1). Como ocorreu ao observarmos a evolução dos tratados por ator, esta disposição permite uma nova análise dos dados, gerando perguntas. Podemos correlacionar a ascensão de alguns temas na arena internacional, com um possível reflexo nos tratados. Destacam-se nesta linha, por exemplo, a tendência ascendente nas últimas duas décadas nos assuntos Social Matters e Environment, e a ascensão mais longa e mais precoce dos tratados relacionados com o desenvolvimento (Development \& Developing Countries). Interessante também ver novo pico de tratados relacionado sob o assunto Military Matters após 2001, provavelmente relacionado com as ações subseqüentes aos ataques de setembro daquele ano nos Estados Unidos. 


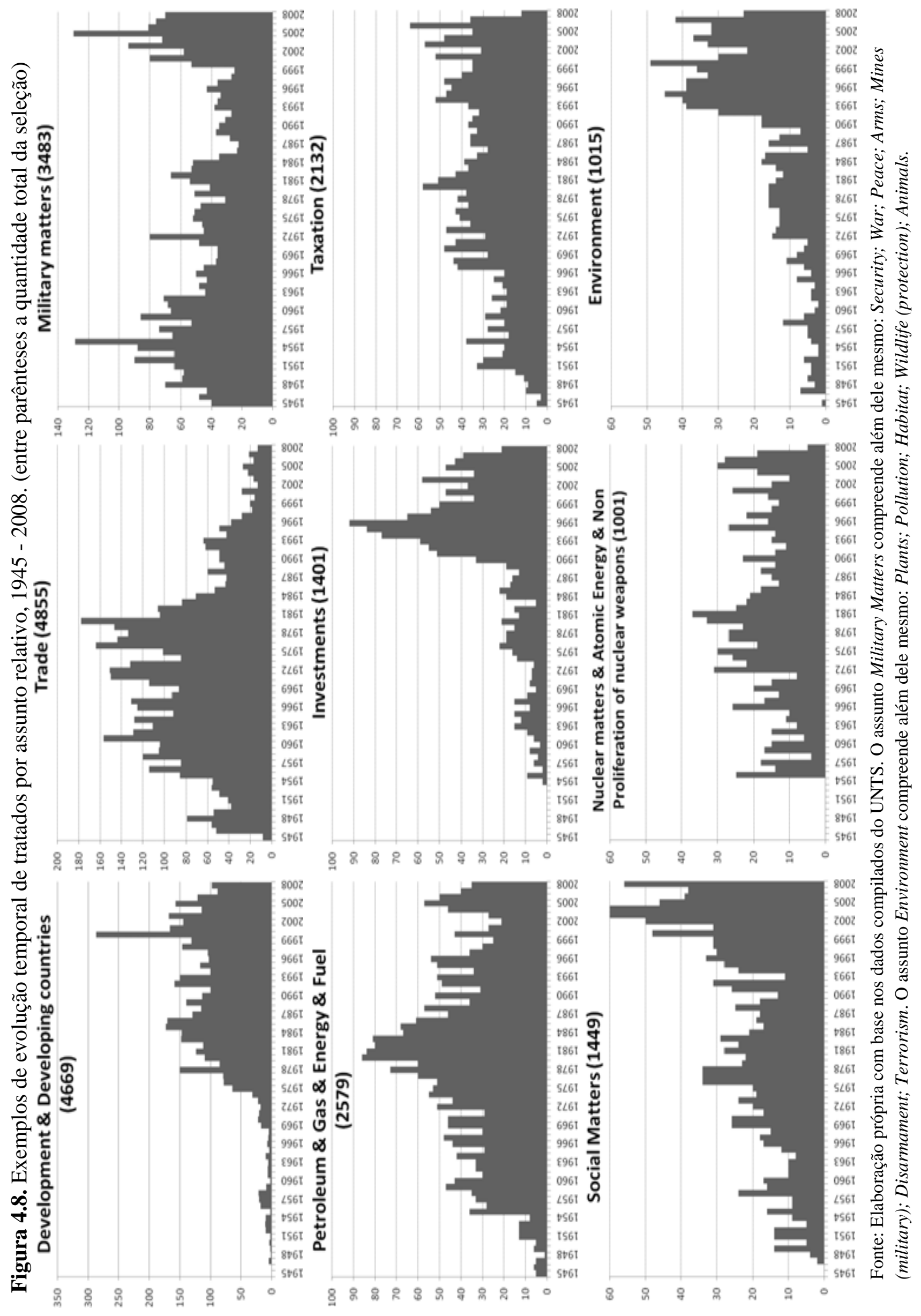


Outros exemplos trazem perguntas cujas respostas são menos aparentes e que se beneficiariam tanto de um aprofundamento nas características relevantes nos dados por meio da sua exploração quanto de informações que só podem ser conseguidas fora do âmbito destas ferramentas. Por exemplo, pode-se fazer um gráfico que mostra congregados os assuntos Petroleum, Gas e Fuel, e correlacioná-lo com os preços internacionais do petróleo como feito abaixo.

Figura 4.9. Evolução dos preços internacionais do petróleo (ajustados para 2011) e da quantidade de tratados relacionados aos assuntos Petroleum, Gas e Fuel, 1945 2007.

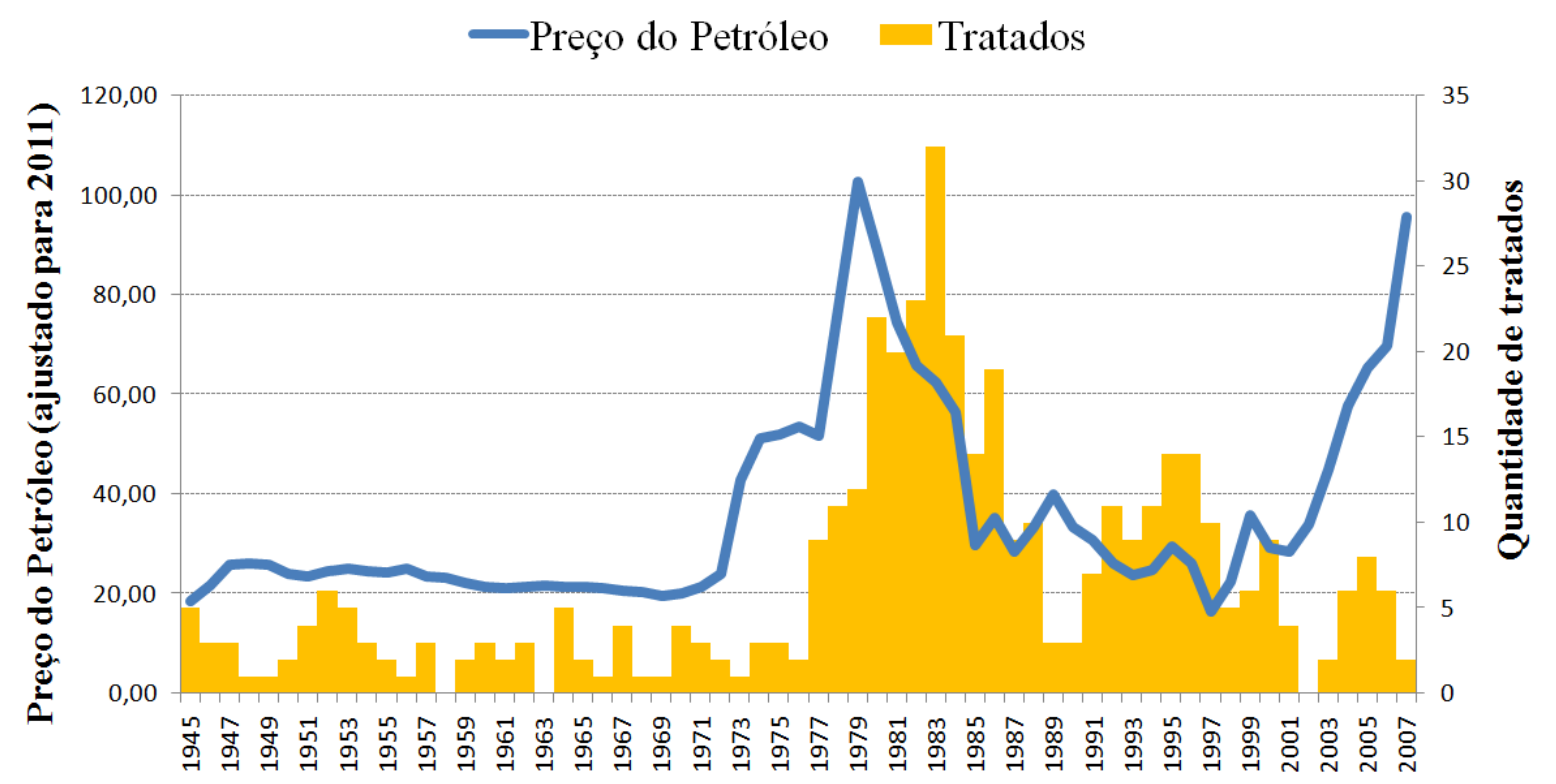

Fonte: Tratados: Elaboração própria com base no UNTS. Cotações históricas do petróleo: United States Energy and Information Administration (www.eia.gov).

Olhando para a linha da cotação do petróleo percebem-se claramente os momentos dos chamados "choques do petróleo" de 1973 e 1979, quando o preço internacional dispara. É interessante notar como o gráfico que representa as quantidades de tratados seguem semelhante padrão geral de crescimento, acompanhando com um pouco de atraso o pico dos preços da década de 1970. Pode-se especular sobre explicações para este atraso, apontando para a distância entre os incentivos a fazer um tratado e a entrada em 
vigor deste, tendo entre estas pontas variadas negociações e burocracias ${ }^{41}$. De todo modo neste caso fica evidente a correlação entre um fator econômico e a política internacional feita por meio de tratados. Com uma olhada ainda mais minuciosa sobre os tratados feitos no período representado pelo pico (de 1977 a 1980), isto é, vendo a lista de títulos dos tratados assinados, percebe-se que uma parte considerável destes tratados se refere a projetos de financiamento para exploração e produção das commodities energéticas. Isto pode significar que não só os atores afetados negativamente por este salto nos preços (como foi o caso do Brasil) fizeram tratados como medida de proteção, mas que mesmo aqueles autossuficientes nesta seara, dada a nova margem de retorno dos negócios, tiveram um atrativo a investir e que muitas vezes isso implicou em tratados.

Escolhemos ainda mais dois exemplos, o ator Brasil e o assunto Trade, para mostrar o aprofundamento exploratório que as manipulações das ferramentas permitem sobre as variáveis presentes nos dados.

Voltando aos gráficos dos assuntos ligados ao comércio (Figura 4.8.) destaca-se a queda brusca dos tratados relacionados com o assunto Trade. Por outro lado, pode-se perceber a ascensão da quantidade de tratados relacionados com os assuntos Taxation e especialmente Investments. Apesar de esses acontecimentos estarem dispostos em momentos distintos é possível supor que a evolução destes dois índices esteja relacionada, assim inserimos os mesmos dados num único gráfico (Figura 4.10.). Fica a pergunta: quais os motivos para que isso se desse desta maneira neste determinado momento? A evolução positiva dos tratados relacionados sob o assunto Trade está concentrada no período do pósguerra. Na passagem da década de 1970 para 1980 uma grande virada ocorre, com a queda abrupta dos tratados assinalados sob esta rubrica. Como na década de 1970 grande parte dos tratados desta seleção tinha como uma das partes os Estados Unidos, o motivo para esta queda abrupta deve ser encontrado também majoritariamente nas ações deste país.

\footnotetext{
${ }^{41}$ Quando as mudanças na política internacional se expressam em um aumento da quantidade de tratados acreditamos que de maneira geral este padrão de atraso entre eles deve ser recorrente pelos motivos já listados. Por outro lado, se as mudanças na política internacional se expressam na forma de queda da quantidade dos tratados ela deve ser imediata.
} 
Figura 4.10. Evolução das quantidades de tratados relacionados aos temas Trade e Taxation \& Investments. 1945-2007.

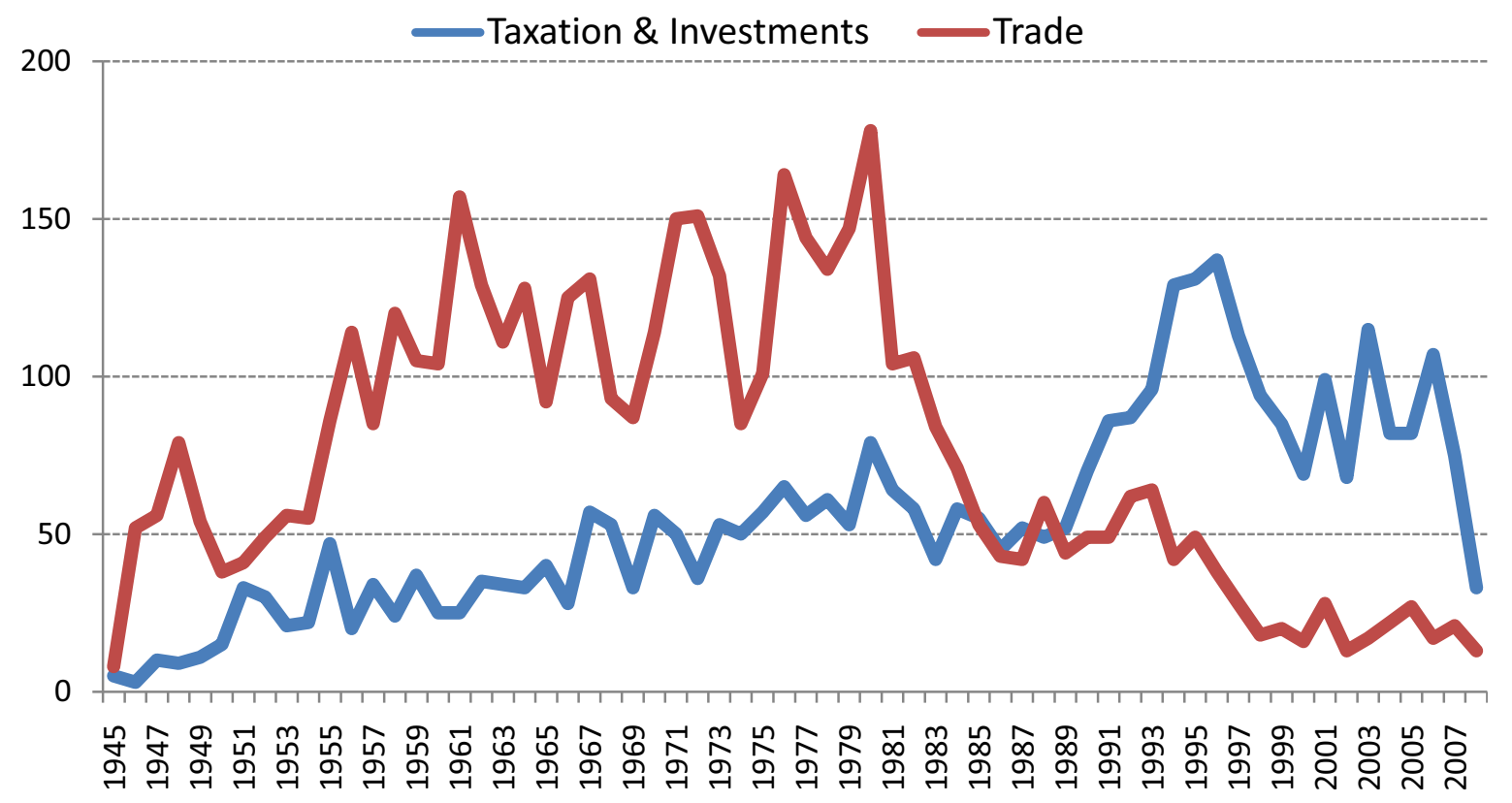

Fonte: Elaboração própria com base nos dados do UNTS.

Podemos lembrar alguns acontecimentos marcantes da época e nos perguntar se estes podem ser trazidos para construir uma explicação sobre estes dados. O chamado "choque Volker", a subida repentina e expressiva dos juros americanos que ocorreu em 1979, ou a eleição de Ronald Reagan em 1980, e um pouco antes, na Inglaterra, a de Margaret Thatcher, podem fazer parte dos fatores elencados para tentar explicar esta mudança substancial?

No entanto, nota-se que a tendência de crescimento dos tratados de taxação e especialmente aqueles que visavam proteger os investimentos externos não veio na mesma década da queda nos tratados de comércio ${ }^{42}$.

\footnotetext{
${ }^{42}$ Um fator para esta diferença de datas pode ser novamente causada pelo tempo necessário para negociar, assinar e entrar em vigor gasto por qualquer tratado.
} 
Figura 4.11. Distribuição dos tratados relacionados aos assuntos General Trade (Azul) e Investments Guarantees (Vermelho).
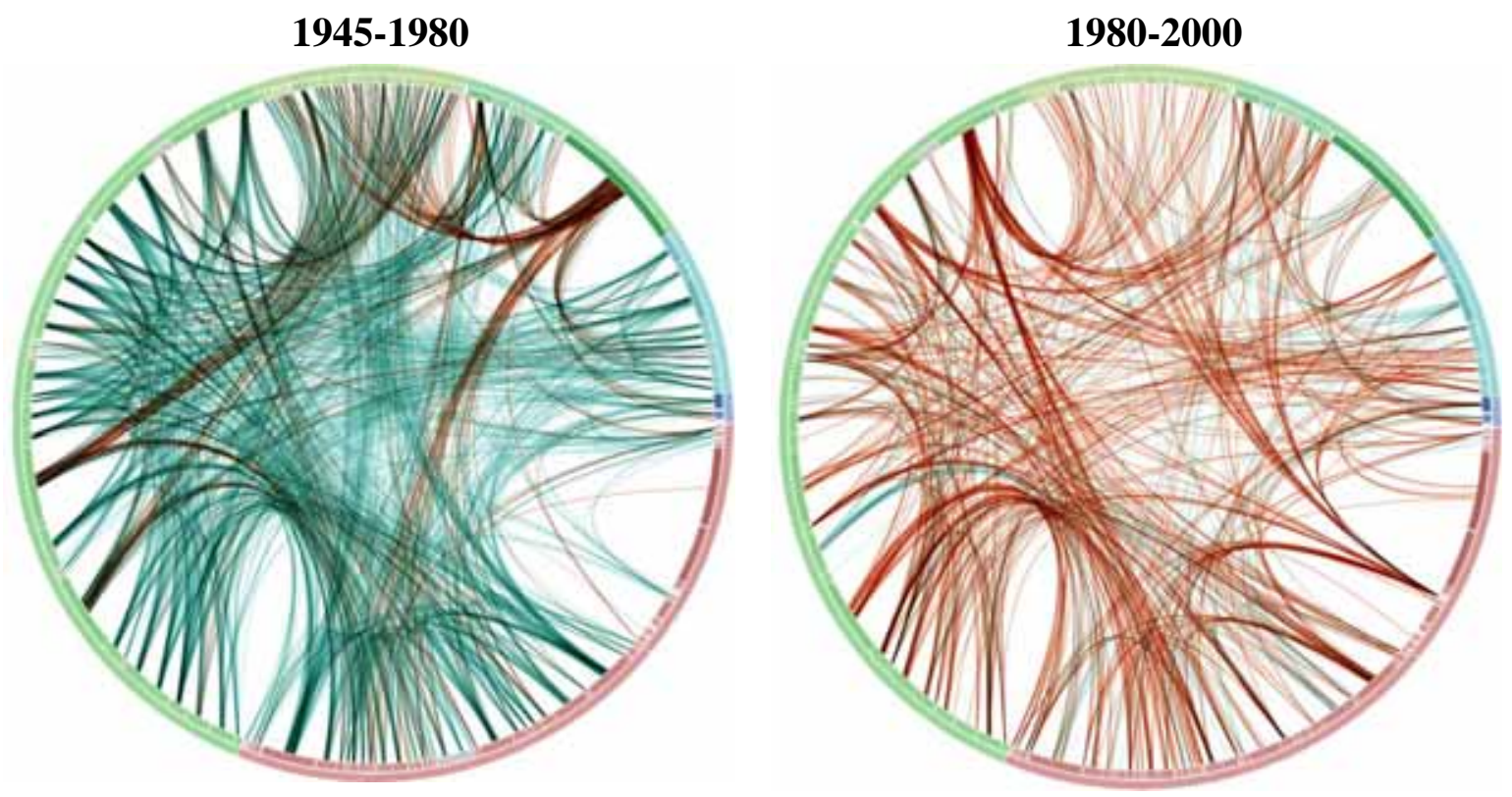

Fonte: Elaboração própria com base nos dados do WTI.

Usando a ferramenta de representação radial como no exemplo acima que mostra, ao mesmo tempo, os tratados relacionados com o assunto Trade e Investments, é fácil perceber que houve mudanças nas quantidades destes, visto que a cor predominante em cada um deles é bastante distinta. Ao interagir com a ferramenta fica claro quem são os desviantes da média. Os Estados Unidos, e em menor medida a Alemanha Ocidental, são os atores que, ao contrário da média, tem maior quantidade de tratados relacionados com investimento antes de 1980, e estes se concentram com países africanos e asiáticos. Depois de 1980, quando há um amplo predomínio de tratados relacionados com investimentos, os tratados de comércio se concentram no Brasil e na Alemanha reunificada.

Somente na década de 1990, tratados sob a rubrica Investments têm um aumento expressivo e bastaste evidente no gráfico, década em que quintuplicaram (UNCTAD, 2000). Novamente podemos fazer o procedimento de elencar acontecimentos importantes da época, como a queda da União Soviética, o fim da Guerra Fria, e a aceitação ou imposição do chamado "Consenso de Washington" para os países da periferia, para 
tentar correlacionar os acontecimentos na esfera política internacional com os padrões de tratados. Podemos especular, por exemplo, que com o fortalecimento do chamado neoliberalismo na década de 1990 se privilegiassem os tratados que protegessem investimentos externos em detrimento de tratados comerciais. Em todo caso a interpretação dos dados neste sentido depende claramente do observador, dado que será ele quem pode decidir quais fatores elencar, ou ter embasamento teórico de tal maneira distinto que leve a entendimentos diferentes destes acontecimentos e, por conseguinte, também das possíveis ligações que os padrões de tratados tenham com estes acontecimentos.

Um exemplo que pode ter maior chance de ser beneficiado com conhecimento prévio do observador são os padrões de tratados do Brasil. Abaixo fazemos uma breve e introdutória exploração destes, tal qual permitido pelas ferramentas, novamente a fim de exemplificar os procedimentos sugeridos para o usuário final. Primeiramente a distribuição espacial dos tratados em três diferentes períodos.

Figura 4.12. Distribuição espacial dos tratados do Brasil, 01/01/1945 01/04/1964.

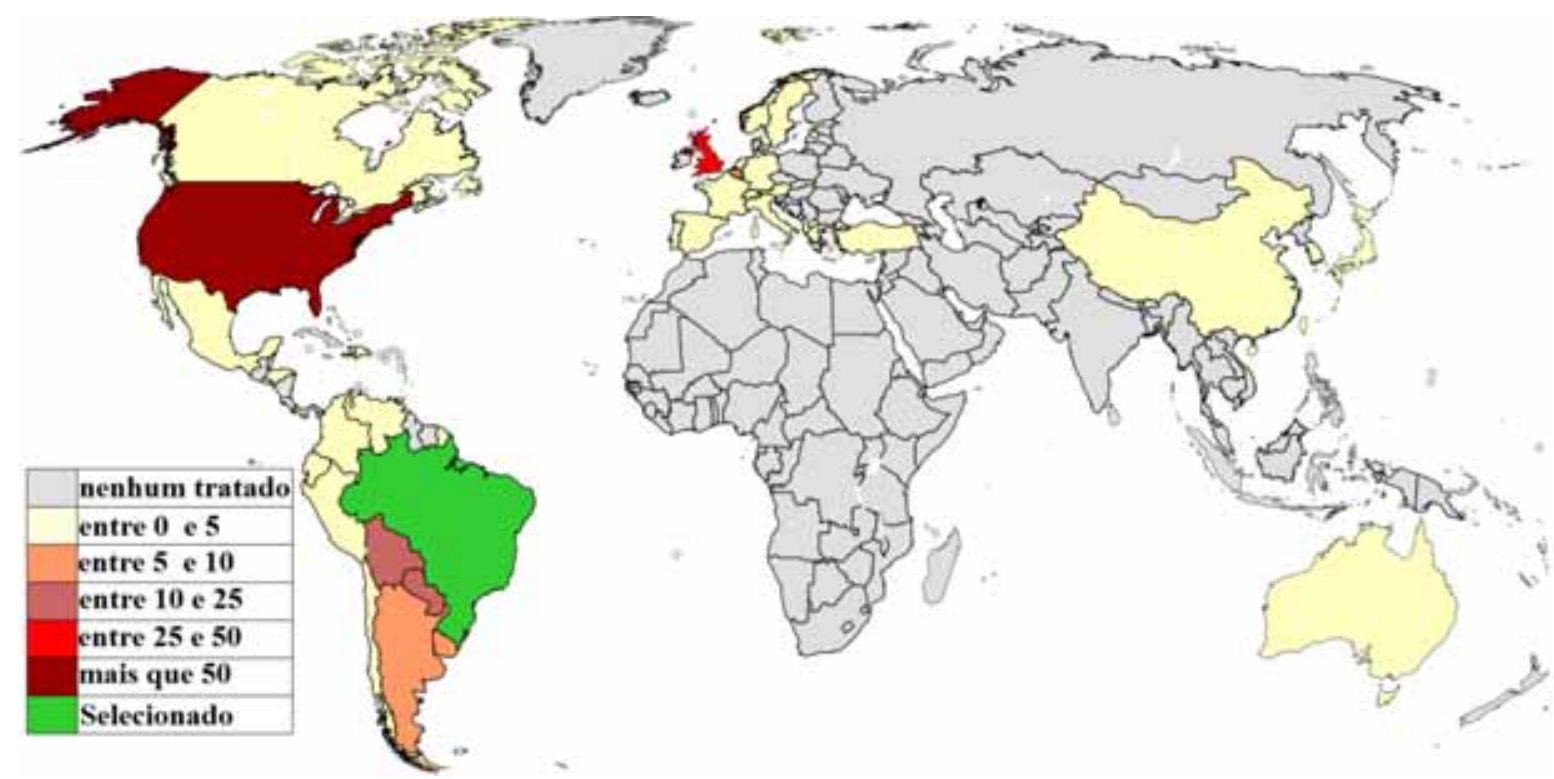

Fonte: Elaboração própria com base nos dados do UNTS. 
Figura 4.13. Distribuição espacial dos tratados do Brasil, 01/04/1964 01/04/1985.

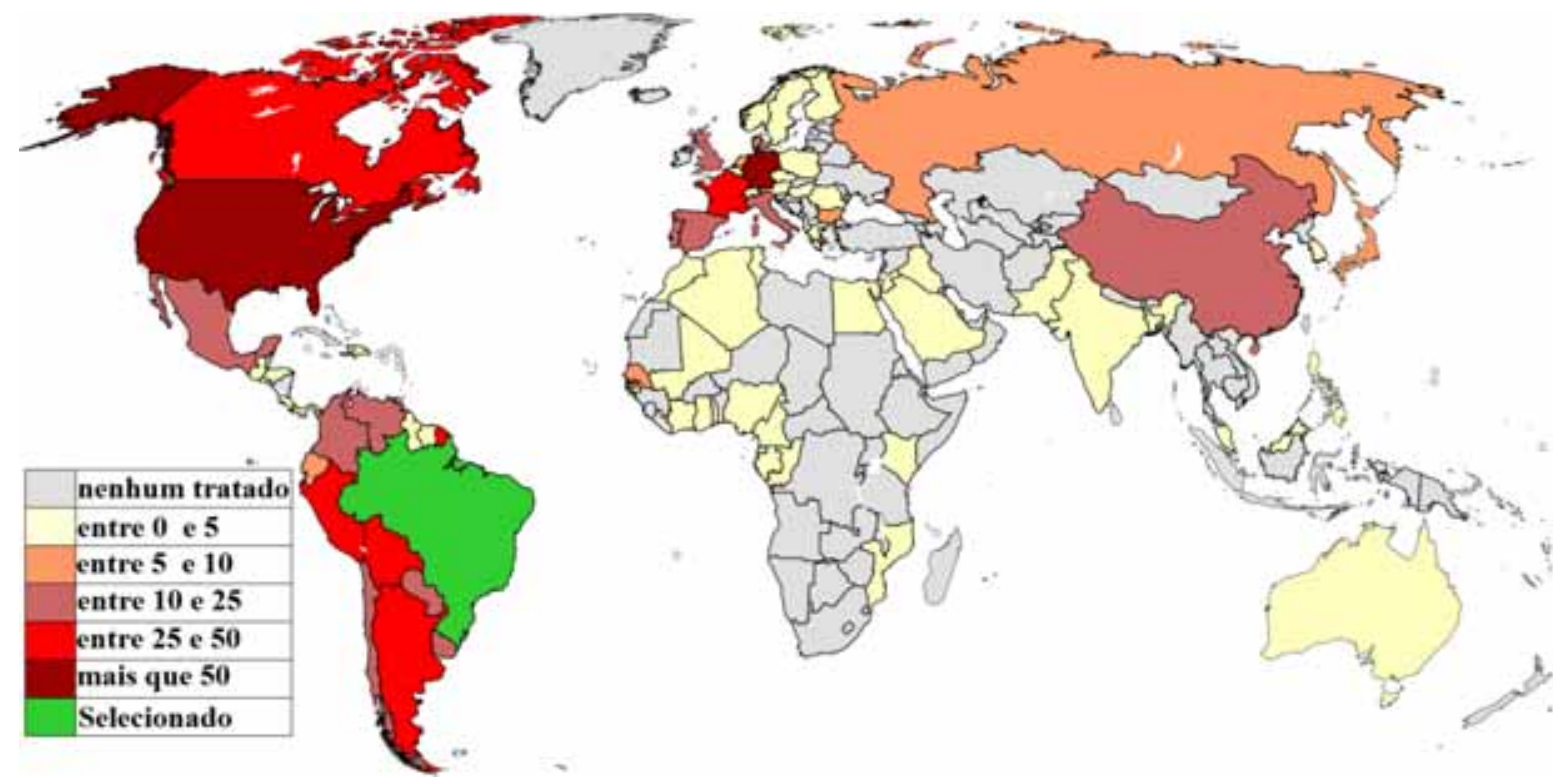

Fonte: Elaboração própria com base nos dados do UNTS.

Figura 4.14. Distribuição espacial dos tratados do Brasil, 01/04/1985 $31 / 12 / 2008$.

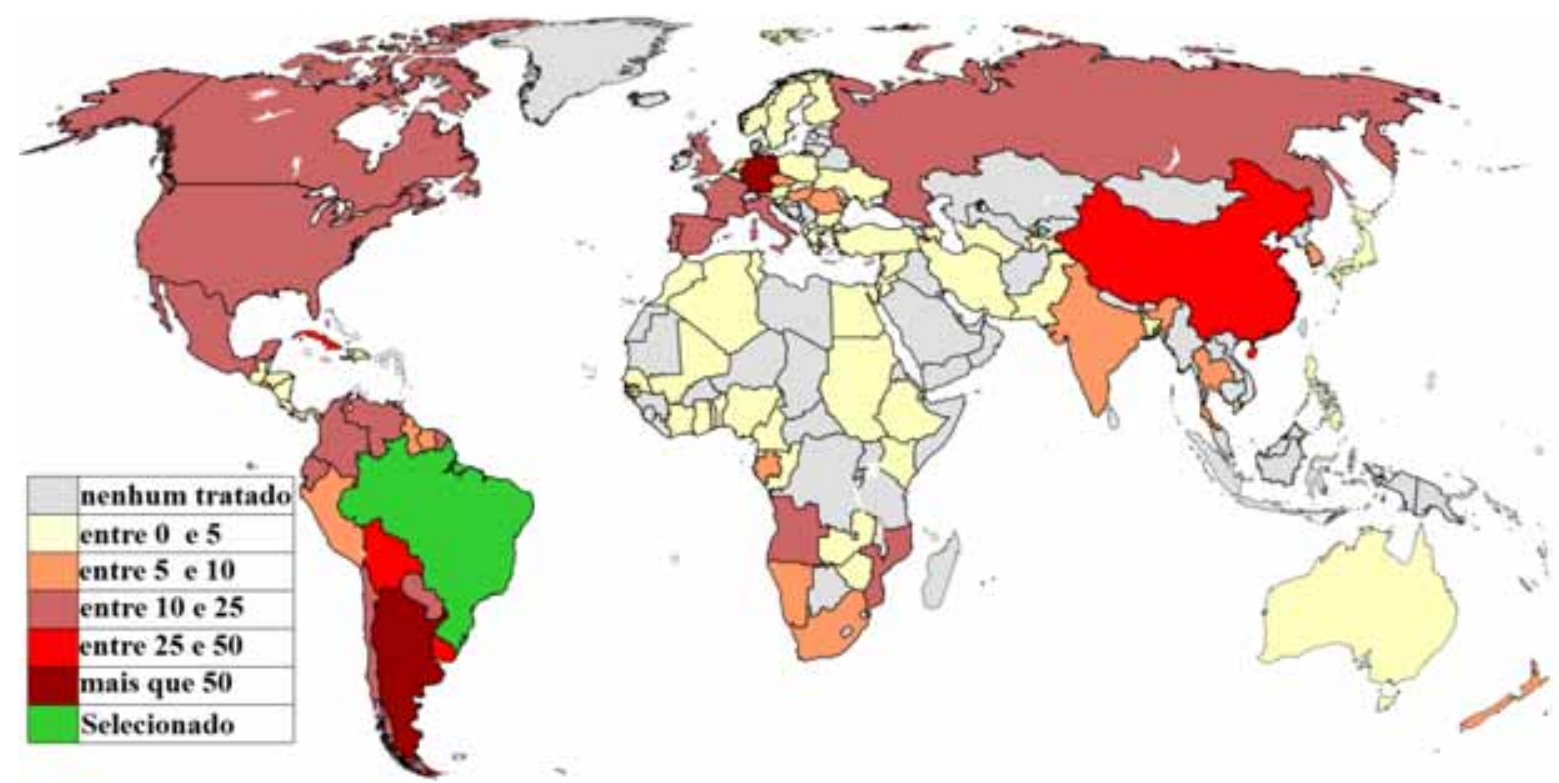

Fonte: Elaboração própria com base nos dados do UNTS. 
Estes exemplos são uma boa oportunidade para relembrar algumas das vicissitudes e dos problemas advindos da formulação dos dados e da construção do mapa apresentados nos capítulos anteriores. Primeiro, quanto mais específica a seleção, isto é, quanto menor for o período ou menor for a quantidade de atores, menor será a quantidade de tratados da seleção e, com isso menor será a segurança das inferências feitas sobre eles. Segundo, deve-se atentar para as seleções feitas pois a amplitude dos períodos é distinta; no caso do período de governo militar são aproximadamente 20 anos congregados. As quantidades destes devem ser comparadas com cuidado com outras visualizações que utilizam períodos menores ou maiores. Terceiro, como visto no capítulo 3 (sessão 3.3.2.), a filiação como membro na ONU ocorre em momentos distintos para muitos destes países, em especial para os africanos. Assim, quando olhamos para a distribuição espacial dos tratados que entraram em vigor entre 1945 e 1964 e vemos que a África se mantém fora do campo dos tratados brasileiros, não podemos interpretar isso politicamente, visto que a maioria destes países não eram à época soberanos e portanto eram incapazes de fazer tratados a não ser sob responsabilidade da sua metrópole. Quarto, os parâmetros para as legendas foram escolhidos por meio de seguidos testes de tal modo que pudéssemos usar a mesma distribuição de cores para todas as visualizações que pretendemos comparar. Desta maneira muitas vezes estes parâmetros de legenda podem não ser os mais adequados para uma seleção específica (visto que foram feitos para todas elas ao mesmo tempo). As ferramentas permitem manipular estes parâmetros se o usuário assim desejar. Quinto, relembramos que os mapas não são adequados para representar atores não territoriais, isto é, Organizações Internacionais ficam de fora desta representação ${ }^{43}$.

Estas considerações inibem mas não impedem que estes dados e representações sejam usados em uma análise exploratória. Tomando o devido cuidado, ao observarmos os mapas podemos perceber, por exemplo, a concentração de tratados brasileiros na América do Sul, o aumento dos tratados feitos com países como Índia e China e aqueles do sul da África, em especial a lusófona, e uma diminuição daqueles feitos com os Estados Unidos.

\footnotetext{
${ }^{43}$ Vale lembrar ainda que os mapas são feitos sobre as linhas fronteiriças de 2011 (veja nota da Figura 3.4.).
} 
É possível também representar os dados separando por assunto relacionado aos tratados. Na Figura 4.15. abaixo expomos alguns exemplos.

Figura 4.15. Evolução da quantidade total de tratados do Brasil, e de alguns assuntos selecionado, 1945-2008.

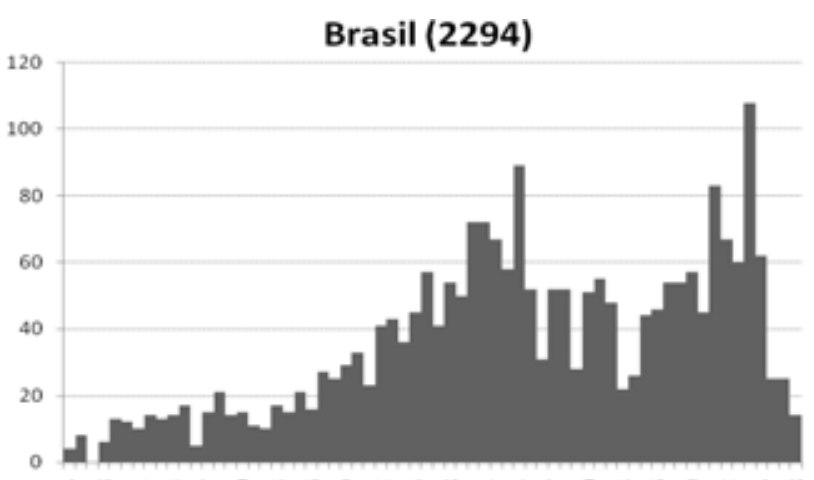

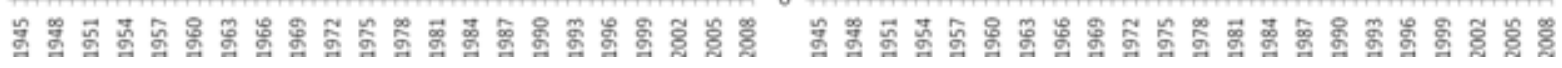
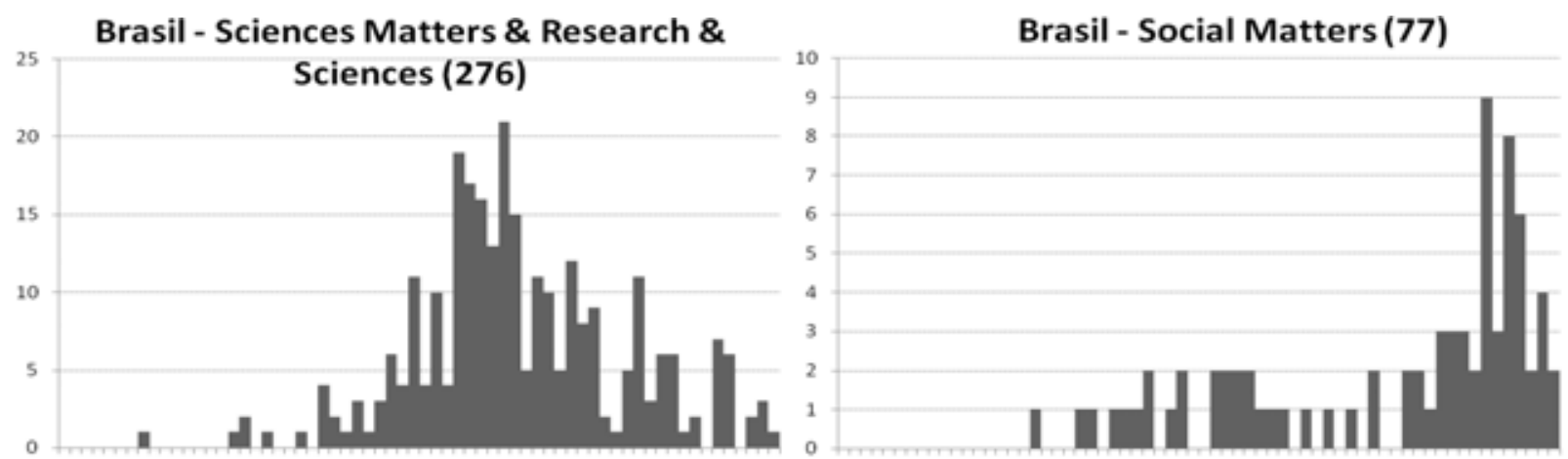

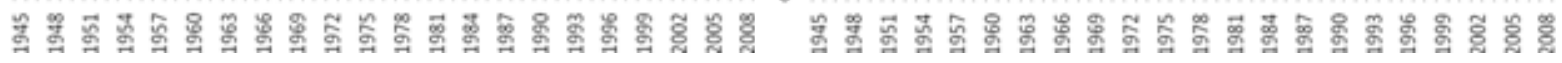

Fonte: Elaboração própria com base nos dados do UNTS.

É possível explorar os dados dos tratados brasileiros de maneira a tentar desvendar quais foram os assuntos mais recorrentes nos dois picos presentes no primeiro gráfico da Figura 4.15., quais são os as estruturas de assuntos em diferentes períodos e podemos nos perguntar os motivos de tal evolução. Ainda há a possibilidade de buscar desvelar quais são os atores com quem estes tratados são feitos em diferentes momentos. Usando as diferentes ferramentas de visualização pode-se representar uma seleção de dados novamente em forma de mapa, desta vez somente com um único assunto dos tratados brasileiros, em busca de alguma nova pista. Como fica evidente, os dados podem ser 
recortados cada vez mais até chegar o momento em que fará mais sentido olhar para a lista de tratados e não mais para os padrões gerais destes.

O número de combinações diferentes entre todas as manipulações das variáveis presentes nos dados e as diferentes maneiras de representá-las visualmente ultrapassa facilmente a casa das centenas de milhares, embora somente uma parte destas tenha realmente algum valor analítico a ser descoberto. E mais do que isso, mesmo entre aquelas que têm valor analítico, a depender do usuário, algumas serão de interesse e outras não. Se o estudioso pretende, ao usar a ferramenta, analisar as relações internacionais ambientais através de tratados, provavelmente não se interessará pelos tratados de comércio, ou se o interesse recair sobre os tratados belgas pouca atenção será dada aos tratados australianos. Isso pode ser visto como um excesso de possibilidades, mas por outro lado permite que tantos interessados no estudo de qualquer um destes atores usem esta ferramenta de forma produtiva e comparada se necessário.

Usando estas ferramentas de apoio o analista pode comparar o que vê com seus conhecimentos e hipóteses já construídas relativas às relações internacionais brasileiras. Ou pode, por outro lado, perceber algo nos mapas que gere novos questionamentos ou novas hipóteses. Usando o exemplo brasileiro, perguntas que poderiam surgir seriam: o que significa politicamente o aumento de tratados relacionados como Social Matters nos últimos anos? Esta é uma tendência mundial ou somente brasileira? Com que atores são estes tratados? Como estão distribuídos espacialmente estes tratados? Como cada governo e sua política externa pode ser interpretado por estes padrões?

\subsection{Conclusão}

O estudo de padrões de tratados é pouco corrente na disciplina de Relações Internacionais, e o banco de dados escolhido não foi alvo de estudos na atual era da informática, logo as ferramentas de visualização de dados também podem ser consideradas novidades para tais estudos. Neste sentido esta pesquisa é exploratória, sem muitos exemplos onde se apoiar, a não ser fora da disciplina. Tivemos o cuidado de pensar e construir tais ferramentas não para a simples análise de dados, como se pudéssemos usá-las para qualquer conjunto de dados, mas sim para uma análise interessada no olhar das 
Relações Internacionais sobre estes dados. Este olhar é múltiplo e variado, o que não impediu seu conjunto de influenciar todo o projeto com implicações profundas no tratamento dos dados, na construção das ferramentas, e em especial na percepção das possibilidades e limites de uso destas ferramentas.

Além desta pesquisa como um todo, as próprias ferramentas propostas também são exploratórias em um sentido distinto: elas foram concebidas para permitirem a manipulação interessada dos dados pelos usuários e a representação das diferentes dimensões presentes nestes, facilitando o entendimento de um conjunto amplo e complexo. São dadas condições para recortar este conjunto de dados de maneiras distintas, atentando para as variáveis presentes nos dados, tais como atores, assuntos e períodos. As diferentes representações visuais permitem a apreensão rápida de dimensões relevantes dos dados das seleções feitas, como qual é a composição geral de atores ou assuntos, sua distribuição espacial e temporal. Tudo isso permite tanto explorações mais abrangentes dos padrões e características relevantes presentes nos dados, quanto ir mais a fundo em busca de características específicas escondidas e até mesmo inesperadas.

Para a realização desta pesquisa, foi necessário nos atermos a dois objetivos práticos: o primeiro foi criar um banco de dados de tratados baseado no banco de dados do UNTS, e o segundo pensar e construir as ferramentas de representação visual que permitissem sua exploração e análise. Estes dois objetivos práticos estiveram interligados, as possibilidades e limites das ferramentas de representação visual determinaram como e quais dados foram coletados durante a compilação, e de um ponto de vista inverso, as representações foram construídas tentando refletir as características presentes nos dados. Um terceiro fator já mencionado influenciou ainda neste processo, a saber, nosso objetivo de construir esta ferramenta voltada para análises de Relações Internacionais.

Devido ao caráter exploratório da pesquisa ao lado destes objetivos práticos está um objetivo de ordem mais teórica: avaliar as possibilidades da ferramenta e seus limites. Para tanto optamos por esmiuçar no corpo deste trabalho os principais fatores influentes em todo o processo de execução deste projeto. No primeiro capítulo discutimos como os tratados são usados por atores internacionais com variadas motivações e formas. Descrevemos as ferramentas no segundo capítulo, isto é, como elas trabalham os dados, 
como estas representam estes dados visualmente, e as consequiências e distorções que estes procedimentos acarretam para o entendimento final destas representações (e, portanto, para as possibilidades de uso das ferramentas). No terceiro capítulo descrevemos a fonte de dados e grande parte de suas características passando pela burocracia do direito internacional até os procedimentos que tomamos para criar um banco de dados paralelo baseado no UNTS. Tudo isso visa dar base para uma análise crítica dos problemas que podem estar presentes entre o longo caminho que vai das relações políticas internacionais mediante tratados e as interpretações dos padrões gerais destes através das ferramentas construídas.

As limitações descritas ao longo do texto se acumulam nas ferramentas reduzindo seu poder epistemológico, o que não impede sua força como ferramenta exploratória. Não se espera que ela apresente muitas respostas, mas que gere conjecturas e perguntas que devem ser respondidas visitando outros conjuntos de dados e utilizando outros métodos. Isto é outra maneira de dizer que as ferramentas mostram somente um recorte especifico da realidade, limitado por suas vicissitudes, e que devem ser usadas criticamente e com apoio de um conjunto mais amplo de ferramentas, métodos e fontes de dados.

Sem fugir da linha do que foi feito nesta pesquisa antevemos possibilidades de melhora nas ferramentas propostas, das quais elencamos três. A primeira seria mesclar os bancos de dados do UNTS e do WTI aumentando a representatividade do conjunto. A segunda seria adicionar uma linha do tempo descrevendo os principais acontecimentos políticos internacionais para comparação pelo usuário com os dados apresentados nas visualizações o que ajudaria na exploração das ligações entre o mundo da política internacional e os padrões de tratados. Como terceira melhoria sugerimos renovar as ferramentas para melhor manipulação dos tratados multilaterais, visto que o foco recaiu aqui mormente nos bilaterais. A ferramenta radial representa primordialmente uma linha por tratado, logo uma sugestão, no caso de multilaterais, seria inscrevê-los como atores fazendo com que a ferramenta atual construa tantas linhas quanto o tratado tem como participantes (ao invés de ligar cada ator participante com todos os outros). Isto permitiria 
manipular para os tratados multilaterais variáveis semelhantes aos tratados bilaterais (como datas e assuntos) e avaliar estas no contexto geral.

Outras possibilidades, mais distantes do que foi aqui feito, são também possíveis: a) construir uma representação de rede que se utilize da posição dos atores como variável mostrando a centralidade do ator no sistema; b) repassar todos os tratados qualificando cada um deles de acordo com sua importância, de maneira a tentar evitar o problema da redução de todos os tratados ao mesmo nível; c) avaliar as correlações dos dados aqui utilizados com outros conjunto de dados ${ }^{44}$. Há muitos casos de correlações possíveis que poderiam ser exploradas, por exemplo, verificar a correlação dos tratados relacionados ao comércio com aumento no fluxo comercial.

Esperamos ter conseguido mostrar que o estudo dos padrões de tratados pode ser produtivo e que este é beneficiado pela ajuda das ferramentas aqui apresentadas. Esperamos também ter conseguido prover o leitor dos instrumentos críticos para avaliar os limites de tal empresa.

\footnotetext{
${ }^{44}$ Há um exemplo próximo quando comparamos os tratados relacionados com petróleo e combustível com os preços internacionais da commodity.
} 


\section{BIBLIOGRAFIA}

ABBOTT, Kenneth W. KEOHANE, Robert O.; MORAVCSIK, Andrew; SLAUGHTER, Anne-Marie; SNIDAL, Duncan. The Concept of Legalization. (2000). In GOLDSTEIN, J. et al. (Ed.). Legalization and World Politics. pp. 17-36. MIT Press, Massashusetts, EUA. 2001.

ADAMS, Jerold L. Japanese Treaty Patterns. Asian Survey, Vol. 12, No. 3, pp. 242-258. University of California Press. Março, 1972.

AUSLIN, Michael R. Negotiating with Imperialism: The Unequal Treaties and the Culture of Japanese Diplomacy. Harvard University Press. EUA. 2006.

AUST, Anthony. The Theory And Practice Of Informal International Instruments. International and Comparative Law Quarterly. VOL. 35, pp. 787-812, 1986.

Press, Inglaterra, 2002. Modern Treaty Law and Practice. $2^{\circ}$ Edição Cambridge University Handbook of International Law. Cambridge University Press,

Inglaterra. 2005.

BARTHEL, Fabian; BUSSE, Matthias; NEUMAYER, Eric. The Impact of Double Taxation Treaties on Foreign Direct Investment: Evidence from Large Dyadic Panel

Data. Contemporary Economic Policy, Vol. 28 (3), pp.366-377. 2010.

BENDER-DEMOLL, Skye. Potential Human Rights Uses of Network Analysis and Mapping: A report to the Science and Human Rights Program of the American Association for the Advancement of Science. 28 de abril de 2008.

BLACK, Jeremy. A History of Diplomacy. Reaktional Books, Inglaterra. 2010.

BRADFORD, William C. International Legal Compliance: Surveying the Discipline.

Bepress Legal Series - Paper 331. Indiana University, EUA. 2004.

BRANDES, Ulrik; KENIS, Patrick; RAAB, Jörg; SCHNEIDER, Volker; WAGNER, Dorothea. Explorations into the Visualization of Policy Networks. Journal of Theoretical Politics. Vol. 11 (1), pp. 75-106. 1999.

BRANDES, Ulrik \& LERNER, Jürgen. Visualization of Conflit Networks. In: KAUfFMAnN, M. (Org.) Building and Using Datasets on Armed Conflicts. 
NATO Science for Peace and Security Series - E: Human and Societal Dynamics, Volume 36. 2009.

BRESCIANI, S. \& EPPLER, M.J. The risks of visualization: a classification of disadvantages associated with graphic representation of information. ICA working paper No 1. 2008.

BURKHARD, Remo A. Learning from Architects: The Difference between Knowledge Visualization and Information Visualization. Proc. Eigth International Conference on Information Visualization (IV04), Londres, Julho de 2004.

BÜTHE, Tim. \& MILNER, Helen V. The Politics of Foreign Direct Investment into Developing Countries: Increasing FDI through International Trade Agreements? American Journal of Political Science. Vol 52 (4) Outubro, 2008.

BUZAN, Barry. The Level of Analysis Problem in International Relations Reconsidered. in BOOTH, Ken \& SMITH, Steve (eds.), International Relations Theory Today, Pennsylvania State University Press, pp.198-216, 1995.

BYERS, Michael. Custom, Power and the Power of Rules: International Relations and Customary International Law. Cambridge University Press, Inglaterra. 2004.

CAPELOVITCH, Mark S. \& PUTNAM, Tonya L. Rationality in Context: Rethinking approaches to the Design of International Agreements. Annual Conference of the American Political Science Association, Washington D.C., EUA, Agosto de 2010 CARD, Stuart K. MACKINLAYU Jack D. SHNEIDERMAN, Ben. (Org.) Readings in Information Visualization: Using Vision to Think. Editora Morgan Kaufman, São Francisco. 1999.

CONFORTI, Benedetto. The Law and Practice of United Nations. $3^{\circ}$ Edição Revisada. Martinus Nijhof Publisher. Leiden, Holanda. 2005.

DENEMARK, Robert A. \& HOFFMANN, Matthew J. Global Cooperation: Treaties and the Dynamics of Multilateralism. Conferência apresentada na International Studies Association. San Diego California, Março, 2006.

It's the Relationships. Trabalho apresentado no Annual Meeting of the International Studies Association, Chicago. 28 de fevereiro, 2007. 
Just Scraps of Paper?: The

Dynamics of Multilateral Treaty-Making. Cooperation and Conflict; 43 (2); pp.185219. 2008[a].

System History: A Network Analysis of the Multilateral Treaty System over 400 Years. Trabalho apresentado em ISA's 49th ANNUAL CONVENTION, São Francisco, USA, 26 de Março de 2008[b].

DOBBERT, J.P. Evolution of the Treaty-Making Capacity of International Organizations.

In: FAO Essays in memory of Jean Carroz. The Law and the Sea. FAO, Itália, 1987.

DROR, I. \& HARNAD, S. Offloading Cognition onto Cognitive Technology. In Dror, I. \& Harnad, S. (Org): Cognition Distributed: How Cognitive Technology Extends Our Minds. Editora John Benjamins, Arsterdam, 2009.

DROR, I.E. Gold mines and land mines in cognitive technology. In DROR, I. E. (Org.). Cognitive Technologies and the Pragmatics of Cognition (pp.1-7). Editora John Benjamin. Amsterdam. 2007.

EBERT, Achim. DIX, Alan. GERSHON, Nahum. POHL, Margit.. Human Aspects of Visualization. In : GROSS et al. (Org.): INTERACT 2009, Part II, LNCS 5727, pp. 965-966. 2009.

ELKINS, Zachary. GUZMAN, Andrew. SIMMONS, Beth. Competing for Capital: The diffusion of Bilatteral Investiment Treaties, 1960-2000. University of Illinois Law Review. Vol. 1, pp.265-304, 2008.

ELSIG, Manfred \& STÜRCHLER, Nikolas. Emerging Patterns of a New International Law: Who Joins the Multilateral Party and Why? ISA Annual Convention, São Francisco, Estados Unidos, 29 de março de 2008.

ESTEVADEORDAL, Antoni. \& SUOMINEN, Kati. Sequencing Trade and Cooperation Agreements. Integration and Regional Programs Departament - Inter-American Development Bank. 2005. 
FISHER , Ali. Mapping The Great Beyond: Identifying Meaningful Networks in Public Diplomacy. CPD Perspectives on public Diplomacy, Paper 2. Figueroa Press, Los Angeles. 2010.

FRIENDLY, Michael \& DENIS, D. Milestones in the history of thematic cartography, statistical graphics, and data visualization. York University. 2009.

GAHEGAN, Mark. Visual Exploration and Explanation in Geography Analysis with Light. In: MILlER, H., \& HAN, J., (Org.) Geographic Data Mining and Knowledge Discovery (pp. 291-324). Taylor \& Francis. 2007.

GARRIGA, Ana Carolina. Regime Type and Bilateral Treaty Formalization Do Too Many Cooks Spoil the soup. Journal of Conflict Resolution, Vol. 53 № 5, pp. 698-726. 2009.

GILBERT, John K.; REINER, Miriam; NAKHLEH, Mary. Visualization: theory and practice in science education. Editora Springer. Dordrecht, Holanda. 2008.

GLEDITSCH, Kristian Skrede, \& WARD, Michael D. Visualization in International Relations. In: MINTZ, Alex \& RUSSETT, Bruce M. (Org). New Directions in International Relations, pp. 65-91. Lexington Books Press, Lexington, 2005.

GOLDSMITH, Jack L. \& POSNER, Eric A. The Limits of International Law. Oxford University Press, New York. 2005.

GOLDSTEIN, Judith.; KAHLER, M.; KEOHANE, R. O.; SLAUGHTER, A. Introduction: Legalization and World Politics. pp. 1-16. In: GOLDSTEIN, J. et al. (Ed.). Legalization and World Politics. MIT Press, Massashusetts, EUA. 2001.

GREEN, T. M.; RIBARSKY, W., e FISHER, B. Visual analytics for complex concepts using a human cognition model. Visual Analytics Science and Technology. IEEE Symposium , pp. $91-98$, novembro 2008.

GUZMAN, Andrew, T. A Compliance Based Theory of International Law. California Law Review, Vol. 90 (6), pp. 1823-1887, dezembro 2002.

HAFNER-BURTON, E. M.; KAHLER, M.; MONTGOMERY, A. H. Network Analysis for International Relations. International Organization, Vol. 63(3), pp. 559-592, 2009. HALLISEY, Elaine J. Cartographic Visualization: An Assessment and Epistemological Review. The Professional Geographer, 57(3), pp. 350-364. Blackwell. 2005. 
HANNA, Gila \& SIDOLI, Nathan. Visualization and proof: a brief survey of philosophical perspectives. In: ZDM Mathematics Education. Vol. 39, pp. 73-78. 2007.

HATHAWAY, Oona A. Treaties'End: The Past, Present and Future of International Lawmaking in the United States. The Yale Law Journal. Vol 117, pp. 1236-1372. 2008.

HELFER, Laurence R. Exiting Treaties. Virginia Law Review. Vol. 91, pp. 1579-1648. 2005 .

HOFFMANN, Michael H. G. Cognitive Conditions of Diagrammatic Reasoning. In SEMIOTICA - Special Issue On Peircean Diagrammatical Logic. Georgia Institute of Technology - School of Public Policy. Atlanta USA. Fevereiro de 2007.

HOLTEN, Danny. Hierarchical Edge Bundles: Visualization of Adjacency Relations in Hierarchical Data. IEEE Transactions on Visualization and Computer Graphics, VOL. 12, NO. 5, Setembro/Outubro 2006.

INTERNATIONAL COURT OF JUSTICE. Anglo-Iranian Oil Co. (jurisdiction) (United Kingdom v. Iran) Judment of July $22^{\text {nd }}$ of 1952. ICJ Reports. p.93. 1952.

JÖNSSON, Christer \& HALL, Martin. Essence of Diplomacy. Editora Palgrave Macmillan, Grã-Bretanha. 2005.

KAHLER, Miles. Conclusion: The Causes and Consequences of Legalization. pp. 277-300. In: GOLDSTEIN, J. et al. (Ed.). Legalization and World Politics. MIT Press, Massashusetts, EUA. 2001.

KEOHANE, Robert O. International Relations and International Law: Two Topics. Harvard International Law Journal. Vol. 38 pp. 487-502. 1997.

KOHONA, Palitha T. B. The United Nations Treaty Collection on the Internet Developments and Challenges. International Journal of Legal Information. VOL 30 (3); pp. 397-425. 2002.

KURTZ, Glen S. \& PEAKE, Jeffrey S. Treaty Politics and the Rise of Executive Agreements: International Commitments in a System of Shared Powers. The University of Michigan Press, Estados Unidos da América. 2009. 
LANTIS, Jeffrey S. The Life and Death of International Treaties: Double-edged Diplomacy and the Politics of Ratification in Comparative Perspective. Oxford University Press, Inglaterra. 2009.

LATOUR, Bruno. Visualization and Cognition: Thinking with Eyes and Hands. In:

KUCLICK, H. (Org.), Knowledge and Society Studies in the Sociology of Culture

Past and Present. Jai Press vol. 6, pp. 1-40. 1986.

LAZER, David. The Free Trade Epidemic of the 1860s and Other Outbreaks of Economic Discrimination. World Politics. Vol. 51 (4), pp.447-483. 1999.

LAZER, David, et al. Computation Social Sciences. Science. Vol. 323 no. 5915 pp. 721 723. 6 de fevereiro, 2009

LESTER, Simon. \& MERCURIO, Bryan (Ed.). Bilateral and Regional Trade Agreements: Commentary and Analysis. Cambridge University Press. Cambridge, Inglaterra. 2009.

LIGA DAS NAÇÕES. Carta da Liga das Nações, Paris, 1919. (Disponível online em http://avalon.law.yale.edu/20th_century/leagcov.asp\#art18, acesso em agosto de 2012).

MANCOSU, Paolo. Visualization in Logic and Mathematics. In: MANCOSU, Paolo; JØRGENSEN, K.F.; PEDERSEN, S.A. (Orgs.). Visualization, Explanation and Reasoning Styles in Mathematics. SYNTHESE LIBRARY Studies in Epistemology, Logic, Methodology, and Philosophy of Science. Volume 327. Springer. Holanda. 2005.

MAOZ, Zeev. \& TERRIS, Lesley G. International Relations: a Network Approach. Apresentação na Gilman Conference on New Directions in International Relations. Yale University, Fevereiro, 2003

MAOZ, Zeev. Network of Nations: The Evolution, Structure, and Effects of International Networks, 1816-2001. Department of Political Sciences, University of California. Janeiro de 2009.

MERKL, D.; SCHWEIGHOFER, E. En route to data mining in legal text corpora: clustering, neuralcomputation, and international treaties. Database and Expert Systems Applications, VOL. 1-2, pp. 465-470, setembro 1997. 
MARTIN, Lisa. The President and International Commitments: Treaties as Signaling Devices. Presidential Studies Quarterly V.35 (3), pp. 440-465, 2005.

MILES, Thomas J. \& POSNER, Eric A. Which States Enter Into Treaties, and Why? John m. Olin law \& Economics Working Paper no. 420. Public Law and Legal Theory Working Paper no. 225. The Law School, University of Chicago. Agosto, 2008.

MITCHELL, Ronald B. International Environmental Agreements: A Survey of Their Features, Formation, and Effects. Annual Review Environmental Resources. Vol. 28, pp. 429-61, 2003.

MONMONIER, M. How to lie with maps. ( $2^{\circ}$ edição) University of Chicago Press. Chicago e Londres.1996.

MONTGOMERY, Alexander H. Quantitative Social Network Analysis and Relationalism: Pathologies and Potentials. Trabalho apresentado na $50^{\text {th }}$ Annual Convention of the International Studies Association. Nova York. Fevereiro 2009.

NEUMAYER, Eric. Geography, Power and Ideology: Diplomatic Representation in a Spatial, Unequal and Divided World. Research Papers in Environmental and Spatial Analysis No. 122. The London School of Economics and Political Science. Londres. 2007.

NIEROP, Tom. Systems and regions in global politics : an empirical study of diplomacy, international organization, and trade, 1950-1991. New York: Jokn Wiley \& Sons. 1994.

OGANDAGA, Muriel Djella; REQUESENS, Arturo. Registration of Treaties under Article 102 of the Charter of the United Nations. Seminar on the undertaking of Treaty Actions for Treaties. Sede da ONU, Nova York. Novembro, 2009.

ONU[a]. Carta das Nações Unidas, Nova York. 1945.

ONU[b]. United Nations Treaty Collection Overview. Acesso em 16 maio 2011. http://treaties.un.org/Pages/Overview.aspx?path=overview/overview/page1_en.xml. ONU[c]. Registration and Publication of Treaties and International Agreements: Regulations to Give Effect to Article 102 of the Charter of the United Nations. (Adopted by the General Assembly on 14 December 1946 [Resolution 97 (1)], as modified by resolutions $364 \mathrm{~B}$ (IV), 482 (V) and 33/141 A, adopted by the General 
Assembly on 1 December 1949, 12 December 1950 and 18 December 1978, respectively)

ONU[d]. Treaty Handbook. Preparado pela Treaty Section of the Office of Legal Affairs. United Nations Publications No. E.02.V2, Nova York, 2006.

ONU[e] Treaty Reference Guide. (disponível em http://untreaty.un.org/olainternet/assistance/guide.pdf ultimo acesso em 16 maio 2011). 1999

ONU[f]. United Nations Conference on the Law of Treaties - Second Session. Summary Records of the plenary meetings of the committee of the Whole. Viena 9 de abril a 22 de maio de 1969.

ONU[g]. Summary of Practice of the Secretary-General as Depositary of Multilateral Treaties. United Nations Publications E.94.V.15, Nova York. 1999.

ONU[h]. Repertory of Practices of United Nations Organs: Extracts relating to Article 102 of the Charter of the United Nations. Codification Division: Office of Legal Affairs. United Nations. V. 5, 1955; Supplement $N^{\circ} 1$ (1954-1955) V.2, 1956; Supplement No 2 (1955-1959) V.3, 1960; Supplement No 3 (1959-1966) V.4, 1967; Supplement No 4 (1966-1969) V.2, 1970; Supplement No 5 (1970-1978) V.5, 1979; Supplement No 6 (1979-1984) V.6, 1985; Supplement No 7 (1985-1988) V.6, 1989; Supplement No 8 (1989-1994) V.6, 1995; Supplement No 9 (1995-1999) V.6, 2000; Supplement No 10 (2000-2009) V.6, 2010.

PENNA-FORTE, Marcelo do Amaral. Iconografia Científica: um estudo sobre as representações visuais na ciência. Tese de doutorado apresentado ao Instituto de Filosofia e Ciências Humanas da Universidade Estadual de Campinas. Campinas. 2006.

PETERSON, Donald Ed. Forms of Representation: An interdisciplinary Theme in cognitive sciences. Intellect Books, Wiltshire, Inglaterra, 1996

PRICE, Sara Janet. Diagram Representation: The Cognitive Basis for Understanding Animation in Education. Tese de doutorado em filosofia da Universidade de Sussex, Inglaterra. Cognitive Science Research Paper 553. 2002.

POLlinS, B. M. Does trade still follow the flag? American Political Science Review. VOL. 83, pp. 465-480. 1989 
RAUSTIALA, Kal. Form \& Substance in International Agreements. UCLA Law School. Draft, fevereiro de 2004.

REUS-SMIT, Christian. The Constitutional Structure of International Society and the Nature of Fundamental Institutions. International Organization. Vol. 51(4), pp. 555-89. 1997.

ROHN, Peter H. Canada in the United Nations Treaty Series: A Global Perspective. Canadian Yearbook of International Law, V. 102. 1966.

Quarterly, Vol. 12, No. 2, pp. 174-195. Junho, 1968.

ROTHMAN, Steven B. Understanding Data Quality through Reliability: A Comparison of Data Reliability Assessment in Three International Relations Datasets. International Studies Review. V. 9, pp. 437-456. 2007.

RUSSETT, B. M. and LAMB, W. C. Global patterns of diplomatic exchange, 1963-64. Journal of Peace Research VOL. 6, pp. 37-54. 1969.

SCHRODT, Phillip A. Event Data in Foreign Policy Analysis. In. NEACK, Laura et al. Foreign Policy Analysis: Continuity and Change in Its Second Generation. Prentice Hall, Nova York. 1993.

international event data. In. CIOFFI-REVILLA, C. (Ed.) Power laws in social sciences: Discovering complexity and non-equilibrium dynamics in the social universe. (Disponível em: http://web.ku.edu/keds/papers.dir/Schrodt.PL.2005.pdf , acesso em março 2012). 2005.

SCOTT, Gary L. Treaties of the People's Republic of China: A Quantitative Analysis. Asian Survey, Vol. 13, No. 5. pp. 496-512. Maio, 1973.

SETEAR, John K. An Iterative Perspective on Treaties: a Synthesis of International Relations Theory and International Law. 1996.

SHINOBU, Takashi. China's Bilateral Treaties, 1973-82: A Quantitative Study. International Studies Quarterly. Vol. 31, No. 4, pp. 439-456. Dezembro, 1987. 
SIMMONS, Beth A. \& HOPKINS, Daniel J. The Constraining Power of International Treaties: Theory and Methods. American Political Science Review. Vol. 99, No. 4. Novembro 2005.

SINGER, J. David. The Level-of-Analysis Problem in International Relations. World Politics, Vol. 14, No. 1, pp. 77-92, outubro 1961.

SMALL, M. \& SINGER, J. D. The diplomatic importance of states, 1816-1970: an extension and refinement of the indicator. World Politics VOL. 25, pp. 577-599. 1973.

STEIN, Jana Von. Do Treaties Constrain or Screen? Selection Bias and Treaty Compliance. American Political Science Review. Vol. 99, No. 4. Novembro 2005

STENNING, K. \& OBERLANDER, J. A cognitive theory of graphical and linguistic reasoning: logic and implementation. Cognitive Science , 19, 97 - 140. 1995.

STONE, Maureen. Information Visualization: Challenge for the Humanities. In: CLIR. Working Together or Apart: Promoting the Next Generation of Digital Scholarship (pp. 43-57). CLIR Publications No. 145. 2009.

TUFTE, Edward. Envisioning Information. Cheshire. Graphics Press. 1990.

Visual Explanations: Images and Quantities, Evidence and narrative.

Cheshire. Graphics Press. 1997

Graphics Press, 2001.

TRISKA, Jan F. Soviet Treaty Law: A Quantitative Analysis. Law and Contemporary Problems, Vol. 29, No. 4, (The Soviet Impact on International Law) pp. 896-909. 1964.

UNCTAD. Bilateral Investment Treaties 1959-1999. United Nations, Nova York e Genebra. 2000.

UNITED STATES SENATE, Committee of Foreign Relations. Treaties and Other International Agreements: The Role of The United States Senate. Preparado pelo Congressional Research Service, Library of Congress. $2^{\text {nd }}$ Session of $106^{\text {th }}$ Congress. Print 106-71. 2001. 
VIENA CONVENTION ON THE LAW OF TREATIES 1969. (Disponível em http://untreaty.un.org/ilc/texts/instruments/english/conventions/1_1_1969.pdf )

VOIGT, Stefan. The Economics of Informal International Law - An Empirical Assessment. Working Paper Series, 2011. (disponível em: http://ssrn.com/abstract=1835963 acesso em março 2012)

WASSERMAN, Stanley, and FAUST, Katherine. Social Network Analysis: Methods and Applications. Cambridge, Inglaterra, Cambridge University Press, 1994.

WIJK, Jarke J. van. The Value of Visualization. Proceedings of IEEE on Visualization pp.79-86. 2005.

WILSON, Woodrow. Discurso proferido ao congresso americano em 8 de janeiro de 1918.

Records of the United States Senate; Record Group 46. National Archives. (acesso em março de 2012 http://www.ourdocuments.gov/doc.php?doc=62)

WOODS, John. \& ROSALES, Alirio. Virtuous Distortion: Abstraction and Idealization in Model-Based Science. In. Model Based Reasoning in Science and Technology: Abduction, Logic, and Computational Discovery. MAGNANI, L.; CARNIELLI, W. \& PIZZI, C. (Eds.). Editora Springer, Alemanha. 2010.

WORLD TREATY INDEX. (www.worldtreatyindex.com acesso em março 2012).

WUSTEN, Herman; DENEMARK, Robert A; HOFFMANN, Matthew; YONTEN, Hasan. The Map of Multilateral Treaty-Making 1600-2000: A contribution to the Historical Geography of Diplomacy. Tijdschrift voor economische en sociale geografie. Vol. 102 (5), pp. 499-514. 2011.

YOO, John. Rational Treaties: Article II, Congressional-Executive Agreements, and International Bargaining. Berkley Program in Law ans Economics, Working Paper Series. 2011. (disponível em http://escholarship.org/uc/item/99f758qd)

ZAWAHRI, Neda A. \& MITCHELL, Sara Mclaughlin. Fragmented Governance of International Rivers: Negotiating Bilateral versus Multilateral Treaties. Trabalho apresentado na "2009 Annual Meeting of the International Studies Association", Nova York, 15-18 de Fevereiro, 2008.

ZINOVYEV, Andrei. Data visualization in political and social sciences. Institut Curie, Paris, 2010. 


\section{ANEXOS}

Anexo I - Lista de atores e quantidades de tratados no banco de dados do Treaty Section do Office of Legal Affairs da ONU (1900 - 2010).

Abu Dhabi (1)

Afghanistan (148)

African and Malagasy Coffee Organization

(1)

African and Malagasy Organisation for

Economic Co-operation (1)

African Development Bank (9)

African Development Fund (1)

African Export-Import Bank (1)

African Groundnut Council (1)

African Intellectual Property Organization (2)

African Regional Centre for Technology (1)

African Trade Insurance Agency (4)

African Union (3)

African, Carribean and Pacific Group of States (1)

Afro-Asian Rural Reconstruction

Organization (2)

Agency for Cultural and Technical Cooperation (9)

Agency for the Prohibition of Nuclear Weapons in Latin America (2)

Agency for the Prohibition of Nuclear

Weapons in Latin America and the Caribbean (1)

Ajman (1)

Albania (244)

Algeria (247)

Allied High Commission for Germany (1)

Andean Community (2)

Andean Development Corporation (10)

Andorra (14)

Anglo-Egyptian Sudan (1)

Angola (72)

Antigua and Barbuda (21)

Arab Atomic Energy Agency (1)

Arab Center for the Studies of Arid Zones and Dry Lands (6)

Arab Fund for Economic and Social

Development (1)
Arab Industrial Development Organization (1)

Arab Labour Organization (1)

Arab League Educational, Cultural and Scientific Organization (2)

Arab Maghreb Union (1)

Arab Organization for Agricultural Development (1)

Arab Organization for Mineral Resources (2)

Arab Organization for Standardization and Metrology (1)

Argentina (850)

Armenia (114)

Aruba (4)

Asian Development Bank (22)

Asian Productivity Organization (1)

Association of Caribbean States (2)

Association of Iron Ore Exporting

Countries (1)

Association of South-East Asian Nations

(4)

Association of Tin Producing Countries (1)

Australia (1039)

Austria (1180)

Austria-Hungary (4)

Azerbaijan (103)

Bahamas (40)

Bahrain (40)

Bangladesh (472)

Bank for International Settlements (1)

Bank of the Central African States (1)

Barbados (79)

Belarus (99)

Belgian Congo (1)

Belgium (1151)

Belgium (on behalf of Belgium and Luxembourg in the name of the Belgo-

Luxembourg Economic Union) (117)

Belize (51) 
Benelux Organisation for Intellectual Property (1)

Benin (183)

Bhutan (39)

Black Sea Economic Cooperation (1)

Bolivia (507)

Border Environment Cooperation Commission (1)

Bosnia and Herzegovina (85)

Botswana (133)

Brazil (2347)

British Guiana (2)

British Occupation Authorities in Germany (1)

British/US Zone of the Free Territory of Trieste (7)

Brunei Darussalam (16)

Bulgaria (549)

Burkina Faso (143)

Burma (172)

Burundi (139)

Byelorussian Soviet Socialist Republic (2)

CAB International (3)

Cambodia (112)

Cameroon (229)

Canada (1593)

Cape Verde (124)

Cape Verde Islands (1)

Caribbean Agricultural Research and Development Institute (1)

Caribbean Community (10)

Caribbean Development Bank (24)

Caribbean Free Trade Association (1)

Caribbean Meteorological Organisation (1)

CARIFORUM (1)

Central African Economic and Monetary Community (3)

Central African Empire (3)

Central African Republic (103)

Central African States Development Bank (2)

Central American Bank for Economic Integration (8)

Central American Integration System (1)

Central Bank of the West African States (2)

Central Commission for the Navigation of the Rhine (1)

Central-American Commission

on Environment and Development (2)

Chad (151)

Channel Islands (1)

Chile (502)

China (1063)

China (for Macao Special Administrative Region) (1)

Colombia (647)

Commission for East African Cooperation (1)

Commission for Environmental Cooperation (2)

Commission for Technical Co-operation in Africa South of the Sahara (1)

Commission for the Conservation of Antarctic Marine Living Resources (2)

Commission for the Conservation of Southern Bluefin Tuna (1)

Commission of the European Communities (4)

Commission to the Cartagena Agreement (3)

Common Fund for Commodities (26)

Common Market for Eastern and Southern Africa (1)

Commonwealth Agricultural Bureaux (1)

Commonwealth Foundation (1)

Commonwealth of Independent States (1)

Commonwealth of Learning (2)

Commonwealth Secretariat (2)

Commonwealth

Telecommunications Organisation (1)

Comoros (53)

Congo (100)

Congo (Brazzaville) (4)

Congo (Leopoldville) (15)

Congo People's Republic (4)

Consultative Group on International Agricultural Research (International Service for National Agricultural Research) (2)

Contracting Parties to the General Agreement on Tariffs and Trade (1)

Cook Islands (16)

Cooperation Council for the Arab States of the Gulf (4) 
Costa Rica (248)

Council for Mutual Economic Assistance (9)

Council of Europe (3)

Council of Ministers of the West-African Monetary Union (1)

Council of the Entente (2)

Croatia (122)

Cuba (237)

Curacao (1)

Customs Co-operation Council (2)

Cyprus (260)

Czech and Slovak Federal Republic (25)

Czech Republic (125)

Czechoslovakia (606)

Dahomey (37)

Democratic Kampuchea (1)

Democratic People's Republic of Korea (43)

Democratic Republic of the Congo (70)

Democratic Republic of Viet-Nam (13)

Democratic Yemen (68)

Denmark (1245)

Desert Locust Control Organisation for Eastern Africa (1)

Development Bank for Central African States (1)

Djibouti (60)

Dominica (44)

Dominican Republic (255)

Dubai (1)

East African Common Services Authority (1)

East African Community (6)

East African Community (Terminated) (1)

East-African Common Services Organization (2)

Economic and Statistical Observatory of Sub-Saharan Africa (1)

Economic Community of the Great Lakes Countries (1)

Economic Community of West African States (8)

Economic Cooperation Organization (10)

Ecuador (420)

Egypt (657)

El Salvador (266)
Energy Charter Conference (1)

Equatorial Guinea (52)

Eritrea (36)

Estonia (258)

Ethiopia (369)

Eurojust (3)

European and Mediterranean Plant Protection Organization (1)

European Atomic Energy Community (29)

European Bank for Reconstruction and Development (3)

European Centre for Medium-Range Weather Forecasts (6)

European Chemicals Agency (1)

European Coal and Steel Community (4)

European Communities (1)

European Communities and their Member States (24)

European Community (41)

European Economic Community (64)

European Environment Agency (2)

European Forest Institute (1)

European Free Trade Association (1)

European Investment Bank (2)

European Molecular Biology Laboratory (3)

European Monetary Institute (1)

European Monitoring Centre on Racism and Xenophobia (1)

European Organisation for Nuclear Research (8)

European Organisation for the Exploitation of Meteorological Satellites (1)

European Organization for the Development and Construction of Space Vehicle Launchers (2)

European Organization for the Safety of Air Navigation (7)

European Patent Organisation (12)

European Police College (1)

European Police Office (4)

European School (2)

European Southern Observatory (1)

European Space Agency (22)

European Space Research Organisation (22)

European Space Vehicle Launcher Development Organisation (2) 
European Telecommunications Satellite Organization (2)

European Union (2)

Executive Board Established by the Statute of the European School (1)

Federal Republic of Germany (2739)

Federation of Malaya (31)

Federation of Rhodesia and Nyasaland (28)

Fiji (86)

Finland (1060)

Food and Agriculture Organization of the United Nations (60)

Food and Agriculture Organization of the United Nations (World Food Programme) (35)

France (3214)

French Committee of National Liberation (1)

French Equatorial Africa (1)

French National Committee (1)

French Zone of Occupation of Germany (4)

Fujairah (1)

Gabon (110)

Gambia (122)

Georgia (135)

German Democratic Republic (248)

Germany (2561)

Ghana (372)

Gibraltar (1)

Greece (655)

Greenland (2)

Grenada (45)

Group of Latin American and Caribbean Sugar Exporting Countries (1)

Guatemala (255)

Guinea (205)

Guinea-Bissau (65)

Guyana (132)

Hague Conference on Private International Law (9)

Haiti (244)

Holy See (25)

Honduras (313)

Hong Kong (11)

Hong Kong (under an entrustment of authority from the United Kingdom Government) (33)
Hong Kong Special Administrative Region (under authorization by the Government of China) (41)

Hungary (660)

Ibero-American Social Security Organization (1)

Ibero-American Youth Organization (1)

Iceland (200)

India (1246)

Indonesia (885)

Industrial Property Organization for English-Speaking Africa (1)

Inter-American Center for Tax Administrations (1)

Inter-American Development Bank (22)

Inter-American Indian Institute (1)

Inter-American Institute for Cooperation on Agriculture (10)

Inter-American Institute for Global Change Research (1)

Inter-American Institute of Agricultural Sciences (1)

Inter-American Nuclear Energy Commission (1)

Intergovernmental Authority on Development (4)

Intergovernmental Authority on Drought and Development (1)

Intergovernmental Bureau for Informatics (2)

Intergovernmental Committee for European Migration (3)

Inter-governmental Committee for Migration (3)

Inter-Governmental Council of Copper Exporting Countries (1)

Inter-Governmental Maritime Consultative Organization (17)

Interim Commission for the International Trade Organisation (2)

Interim Commission for the International Trade Organization/GATT (2)

International Atomic Energy Agency (460)

International Bank for Reconstruction and Development (5366)

International Bauxite Association (1)

International Bureau of Education (1) 
International Center for Public Enterprises in Developing Countries (2)

International Centre for Agriculture Research in the Dry Areas (1)

International Centre for Migration Policy Development (2)

International Centre for the Study of the Preservation and the Restoration of Cultural Property (2)

International Centre for Tropical Agriculture (1)

International Centre of Genetic Engineering and Biotechnology (5)

International Civil Aviation Organization (37)

International Civil Defence Organization (2)

International Cocoa Organization (4)

International Coffee Organization (5)

International Commission for the Conservation of Atlantic Tunas (1)

International Commission for the Protection of the Danube River (1)

International Committee of Weights and Measures (1)

International Cotton Advisory Committee (3)

International Council for Exploration of the Sea (1)

International Court of Justice (3)

International Criminal Court (12)

International Criminal Police Organization (6)

International Development AssociatI-42216 (1)

International Development Association (4812)

International Exhibition Bureau (2)

International Finance Corporation (17)

International Fund for Agricultural Development (1113)

International Hydrographic Organization (2)

International Institute for Cotton (2)

International Institute for Democracy and Electoral Assistance (2)
International Institute for the Unification of Private Law (1)

International Institute of Administrative Sciences (1)

International Institute of Refrigeration (1)

International Jute Organization (3)

International Labour Organisation (109)

International Lead and Zinc Study Group (6)

International Maize and Wheat Improvement Center (1)

International Maritime Organization (4)

International Maritime Satellite Organization (1)

International Mobile Satellite Organization (1)

International Monetary Fund (6)

International Natural Rubber Organization (2)

International Nickel Study Group (2)

International Office for dealing with Contageous Diseases of Animals (1)

International Oil Pollution Compensation Fund (4)

International Olive Oil Council (3)

International Organisation for the Development of Fisheries in Eastern and Central Europe (EUROFISH) (1)

International Organisation of Legal Metrology (1)

International Organization for Migration (4)

International Pepper Community (2)

International Refugee Organization (4)

International Relief Union (1)

International Road Traffic Organization (5)

International Rubber Study Group (2)

International Seabed Authority (5)

International Sugar Organization (6)

International Tea Promotion Association (1)

International Telecommunication Union (16)

International Telecommunications Satellite Organization (4)

International Tin Council (2)

International Trade Centre

(UNCTAD/WTO) (1) 


\begin{tabular}{|c|c|}
\hline $\begin{array}{l}\text { International } \\
\text { UNCTAD/GATT }(1)\end{array}$ & $\begin{array}{l}\text { Latin Union (2) } \\
\text { Latin-American Centre for Physics (1) }\end{array}$ \\
\hline $\begin{array}{l}\text { International Tribunal for the Law of the } \\
\text { Sea (4) }\end{array}$ & $\begin{array}{l}\text { Latvia (339) } \\
\text { League of Arab States (8) }\end{array}$ \\
\hline $\begin{array}{l}\text { International Tropical Timber Organization } \\
\text { (4) }\end{array}$ & $\begin{array}{l}\text { League of Nations }(9) \\
\text { Lebanon (179) }\end{array}$ \\
\hline International Visegrad Fund (1) & Lesotho (133) \\
\hline International Whaling Commission (3) & Liberia (197) \\
\hline International Wheat Council (3) & Libya (61) \\
\hline Inter-Parliamentary Union (3) & Libyan Arab Jamahiriya (38) \\
\hline $\operatorname{Iran}(249)$ & Libyan Arab Republic (7) \\
\hline Iran-United States Claims Tribunal (3) & Liechtenstein (30) \\
\hline Iraq (168) & Liptako-Gourma \\
\hline Ireland (456) & Development Authority (3) \\
\hline Islamic Development Bank (2) & Lithuania (354) \\
\hline Isle of Man (2) & Luxembourg (282) \\
\hline Israel (988) & Macau (14) \\
\hline Italy (974) & Madagascar (266) \\
\hline Ivory Coast (259) & Malawi (271) \\
\hline Jamaica (261) & Malaysia (258) \\
\hline Japan (932) & Maldive Islands (2) \\
\hline Joint Vienna Institute (1) & Maldi \\
\hline Jordan (401) & Mali (302) \\
\hline Kazakhstan (120) & Malta ( \\
\hline Kenya (443) & Mano River Union (3) \\
\hline ablic (32) & Marshall Islands (8) \\
\hline Kingdom of the Serbs, Croats and Slovenes & Mauritania (181) \\
\hline Kiribati (11) & Mekong River Commission (3) \\
\hline Korea & Mexico (1415) \\
\hline Kuwait (84) & Mexico-U.S. Commission for Educational \\
\hline Kyrgyzstan & and Cultural Exchange (1) \\
\hline Lake Chad Basin Commission (1) & Micronesia (8) \\
\hline Lao People's Democratic Republic (123) & Moldov \\
\hline Laos (43) & Mona \\
\hline Latin American and Caribbean Institute for & Mongolia (177) \\
\hline Economic and Social Planning (1) & Mont \\
\hline Latin American Economic System (5) & Morocco (530) \\
\hline Latin American Faculty of Social Sciences & Mozambique (192) \\
\hline $\begin{array}{l}\text { (FLACSO) }(2) \\
\text { Latin American Free Trade Association (1) }\end{array}$ & $\begin{array}{l}\text { Multilateral Investment Guarantee Agency } \\
\text { (99) }\end{array}$ \\
\hline $\begin{array}{l}\text { Latin American Handicraft Cooperation } \\
\text { Programme (1) }\end{array}$ & $\begin{array}{l}\text { Multinational Force and Observers (22) } \\
\text { Muscat and Oman (7) }\end{array}$ \\
\hline Latin American Institute for the Prevention & Myanmar (15) \\
\hline of Crime and the treatment of offenders & Namibia (83) \\
\hline (1) & $\mathrm{Nat}$ \\
\hline Latin American Integration Association (4) & Nepal (220) \\
\hline
\end{tabular}


Netherlands (1804)

Netherlands Antilles (2)

New Zealand (615)

Newfoundland (1)

Nicaragua (323)

Niger (215)

Nigeria (240)

Niue (5)

Nordic Development Fund (1)

Nordic Environment Finance Corporation (2)

Nordic Investment Bank (1)

NORSAD Agency (1)

NORSAD Fund (1)

North Atlantic Salmon Conservation Organization (1)

North Atlantic Treaty Organization (15)

North Atlantic Treaty Organization (NATO Maintenance and Supply Organization) (2)

North Pacific Marine Science Organization (2)

North-East Atlantic Fisheries Commission (1)

Norway (743)

Oman (75)

OPEC Fund for International Development (4)

Organisation for Economic Co-operation and Development (7)

Organisation for European Economic Cooperation (2)

Organisation for the Prohibition of Chemical Weapons (4)

Organisation for the Prohibition of Nuclear Weapons in Latin America and the Caribbean (1)

Organization for the Development of the Senegal River (5)

Organization of African Unity (20)

Organization of American States (27)

Organization of Central American States (1)

Organization of Ibero-American States for Education, Science and Culture (1)

Organization of the Islamic Conference (4)
Organization of the Petroleum Exporting Countries (6)

Pakistan (808)

Palau (9)

Pan American Sanitary Organization (1)

Pan American Union (2)

Pan-African Telecommunications (PATU) (1)

Panama (311)

Pan-American Health Organization/World Health Organization (13)

Papua New Guinea (99)

Paraguay (337)

Parliamentary Assembly of the Mediterranean (1)

People's Democratic Republic of Yemen (7)

People's Republic of Kampuchea (9)

Permanent Court of Arbitration (2)

Permanent Executive Secretariat of the 'Andres Bello' Convention (1)

Permanent Inter-State Committee for Drought Control in the Sahel (4)

Permanent Secretariat of the General Treaty on Central American Economic Integration (2)

Persia (4)

Peru (553)

Philippines (788)

Poland (824)

Portugal (495)

Preparatory Commission for the Comprehensive Nuclear Test-Ban Treaty Organization (19)

Preparatory Commission for the Organisation for the Prohibition of Chemical Weapons (1)

Provisional International Civil Aviation Organization (1)

Qatar (43)

Ras Al Khaimah (1)

Republic of Cameroon (2)

Republic of China (154)

Republic of Korea (928)

Republic of Moldova (83)

Republic of South Viet-Nam (3)

Republic of the Congo (8)

Republic of Viet-Nam (125) 
Romania (730)

Russian Federation (353)

Rwanda (169)

Samoa (39)

San Marino (25)

Sao Tome and Principe (41)

Saudi Arabia (144)

Scientific, Technical and Research Commission - Organization of African Unity (1)

Secretariat of the Basel Convention (6)

Secretariat of the Convention on Biological Diversity (2)

Secretariat of the United Nations Convention to Combat Desertification (2)

Senegal (375)

Serbia (9)

Serbia and Montenegro (22)

Seychelles (50)

Sharjah (1)

Sierra Leone (196)

Singapore (227)

Slovakia (101)

Slovenia (106)

Solomon Islands (31)

Somalia (137)

South Africa (283)

South Pacific Commission (4)

South Pacific Forum Fisheries Agency (2)

South-East Asia Treaty Organization (2)

Southeast Asian Ministers of Education Organisation (2)

Southern African Development Community (12)

Southern Rhodesia (1)

Southern Yemen (3)

Soviet Military Administration for Germany (3)

Spain (1639)

Special Court for Sierra Leone (2)

Sri Lanka (386)

St. Kitts and Nevis (27)

St. Lucia (65)

St. Vincent and the Grenadines (39)

Sudan (247)

Sultanate of Nejd (1)
Supreme Commander for the Allied Powers (5)

Supreme Headquarters Allied Powers in Europe (5)

Suriname (56)

Surveillance Authority of the European Free Trade Association (1)

Swaziland (63)

Sweden (1037)

Swiss Confederation (6)

Swiss Federal Council (2)

Switzerland (847)

Syria (43)

Syrian Arab Republic (144)

Tajikistan (60)

Tanganyika (17)

Tanzania (9)

Technical Centre for Agricultural and Rural Cooperation (4)

Thailand (547)

The former Yugoslav Republic of Macedonia (119)

Timor-Leste (28)

Togo (155)

Tonga (45)

Transjordan (7)

Trinidad and Tobago (116)

Trust Fund for the Development of the River Plate Basin (1)

Trust Territory of Western Samoa (19)

Tunisia (482)

Turkey (838)

Turkmenistan (29)

Tuvalu (9)

Uganda (249)

Ukraine (195)

Ukrainian Soviet Socialist Republic (4)

Umm Al Qaiwain (1)

Union of Banana Exporting Countries (1)

Union of South Africa (155)

Union of Soviet Socialist Republics (1215)

United Arab Emirates (51)

United Arab Emirates (Abu Dhabi) (2)

United Arab Republic (128)

United Kingdom of Great Britain and Northern Ireland (3880) 
United Kingdom of Great Britain and Northern Ireland (Belize) (2)

United Kingdom of Great Britain and Northern Ireland (Gilbert Islands) (2)

United Kingdom of Great Britain and Northern Ireland (Hong Kong) (17)

United Kingdom of Great Britain and Northern Ireland (in respect of Bermuda) (5)

United Kingdom of Great Britain and Northern Ireland (in respect of Turks and Caicos Islands) (1)

United Kingdom of Great Britain and Northern Ireland (India) (1)

United Kingdom of Great Britain and Northern Ireland (Kuwait) (3)

United Kingdom of Great Britain and Northern Ireland (on behalf of Antigua) (3)

United Kingdom of Great Britain and Northern Ireland (on behalf of British Honduras) (1)

United Kingdom of Great Britain and Northern Ireland (on behalf of Dominica) (3)

United Kingdom of Great Britain and Northern Ireland (on behalf of Fiji) (2)

United Kingdom of Great Britain and Northern Ireland (on behalf of Grenada) (1)

United Kingdom of Great Britain and Northern Ireland (on behalf of Jamaica) (1)

United Kingdom of Great Britain and Northern Ireland (on behalf of Montserrat) (2)

United Kingdom of Great Britain and Northern Ireland (Palestine) (2)

United Kingdom of Great Britain and Northern Ireland (St. Kitts-NevisAnguilla) (2)

United Kingdom of Great Britain and Northern Ireland (St. Lucia) (1)

United Kingdom of Great Britain and Northern Ireland (St.Vincent) (2)

United Nations (1627)
United Nations (Economic and Social Commission for Asia and the Pacific) (22)

United Nations (Economic and Social Commission for Western Asia) (3)

United Nations (Economic Commission for Latin America and the Caribbean) (71)

United Nations (Economic Commission for Latin America) (7)

United Nations (International Criminal Tribunal for Rwanda) (1)

United Nations (International Criminal Tribunal for the former Yugoslavia) (3)

United Nations (Office of the High Commissioner for Human Rights) (4)

United Nations (Office of the United Nations Disaster Relief Co-ordinator) (16)

United Nations (Techical Assistance Board) (1)

United Nations (United Nations Capital Development Fund) (206)

United Nations (United Nations Centre for Human Settlements) (2)

United Nations (United Nations Children's Fund) (304)

United Nations (United Nations Conference on Trade and Development) (6)

United Nations (United Nations Council for Namibia) (4)

United Nations (United Nations Development Programme) (227)

United Nations (United Nations Economic Commission for Africa) (5)

United Nations (United Nations Environment Programme) (26)

United Nations (United Nations Fund for Drug Abuse Control) (2)

United Nations (United Nations Fund for Population Activities) (6)

United Nations (United Nations High Commissioner for Refugees) (23)

United Nations (United Nations Industrial Development Organization) (53) 
United Nations (United Nations International Drug Control Programme) (4)

United Nations (United Nations Latin American Institute for the prevention of crime and the treatment of offender) (1)

United Nations (United Nations Office on Drugs and Crime) (1)

United Nations (United Nations Population Fund) (7)

United Nations (United Nations Revolving Fund for Natural Resources Exploration) (40)

United Nations (United Nations University) (6)

United Nations (United Nations Volunteers Programme) (1)

United Nations and Food and Agriculture Organization of the United Nations on behalf of the WFP (1)

United Nations Development Programme (14)

United Nations Development Programme (Special Fund) (28)

United Nations Educational, Scientific and Cultural Organization (55)

United Nations High Commissioner for Refugees (41)

United Nations Industrial Development Organization (210)

United Nations Joint Staff Pension Board (11)

United Nations Relief and Rehabilitation Administration (2)

United Nations Relief and Works Agency for Palestine Refugees in the Near East (21)

United Nations Social Defence Research Institute (Rome) (1)

United Nations Special Fund (113)

United Nations Transitional Administration in East Timor (2)

United Republic of Tanganyika and Zanzibar (1)
United Republic of Tanzania (365)

United States of America (11248)

United States United Kingdom and French Military Governors in Germany (3)

United States/British Zones of Occupation in Germany (1)

United States/United Kingdom Military Governments for Germany (5)

United States/United Kingdom Occupied Areas in Germany (2)

Universal Postal Union (9)

University for Peace (3)

Upper Volta (103)

Uruguay (310)

Uzbekistan (112)

Vanuatu (22)

Venezuela (Bolivarian Republic of) (430)

Viet Nam (270)

West African Development Bank (5)

West African Economic and Monetary Union (2)

West African Economic Community (1)

West African Rice Development Association (1)

Western European Union (5)

World Food Programme (1)

World Health Organization (289)

World Health Organization/Pan American Sanitary Bureau (2)

World Intellectual Property Organization (23)

World Meteorological Organization (23)

World Tourism Organization (11)

World Trade Organization (2)

Yemen (63)

Yemen Arab Republic (168)

Yugoslavia (Socialist Federal Republic of) (806)

Zaire (160)

Zambia (258)

Zanzibar (1)

Zimbabwe (123) 


\section{Anexo II - Lista de assuntos relacionados e quantidades de tratados no banco de dados do Treaty Section do Office of Legal Affairs da ONU (1900 - 2010).}

Nota: neste banco de dados cada tratado pode ser relacionado a mais de um assunto, logo a soma destes supera a quantidade total.

\begin{tabular}{|c|c|}
\hline Administration (770) & Conferences-Meetings (851) \\
\hline Adoption (7) & Construction (253) \\
\hline Africa (162) & Cooperation (11070) \\
\hline commodities & Copyright (74) \\
\hline$(2213)$ & Corporations (138) \\
\hline Agriculture (4573) & Council of Europe (1) \\
\hline Alaska (12) & Credits (4574) \\
\hline Alliances (27) & Criminal matters (927) \\
\hline Amazon (21) & Cultural matters (1682) \\
\hline Americas (9) & Customs (555) \\
\hline Animals (190) & Dairy farming (45) \\
\hline Antarctica (11) & Data processing (8) \\
\hline Arab states (6) & Desalination (8) \\
\hline Arbitration and conciliation & Developing countries (76) \\
\hline$(65)$ & Development (4646) \\
\hline Archives (14) & Diplomatic and consular \\
\hline Arms (360) & relations $(565)$ \\
\hline Asia (58) & Disarmament (73) \\
\hline Assistance (4972) & Disaster relief (311) \\
\hline Associations (27) & Diseases (193) \\
\hline Atomic energy & Dispute settlement (93) \\
\hline uses) (209) & Documents (116) \\
\hline Aviation (3055) & Drought (476) \\
\hline Belgo-Luxembourg & Earth sciences (173) \\
\hline Economic Union (16) & East Timor (22) \\
\hline
\end{tabular}

Food and Agriculture Organization of the United Nations (FAO) (58)

Foreign policy (79)

Forestry (271)

Friendship (464)

Frontiers (1083)

Fuels (234)

Gas (105)

General Agreement on Tariffs and Trade (GATT) (31)

Geneva Conventions (40)

Geographical names (399)

Habitat (28)

Headquarters (organizations) (288)

Health and health services (1445)

Housing (117)

Human rights (121)

Humanitarian matters (70)

ICJ jurisdiction (5)

Immigration (94)

Benelux Economic Union (1) Economic Community of

Berlin (West) (6)

Biology (7)

Bridges (93)

West African States (ECOWAS) (6)

Indigenous peoples (10)

Caribbean (80)

Economic matters (1786)

Cartography (162)

Education (2625)

Energy (2221)

Central America (14)

Engineering (145)

Charters-Constitutions-

Environment (736)

Statutes (78)

Europe (213)

Extradition (353)

Chemical products (163)

Fairs-Exhibitions (4)

Family matters (223) (290)

Civil law (68)

Civil matters (366)

Claims-Debts (946)

Films (173)

Finance (6352)

Fishing and fisheries (644)

Commodities (2645)

Food (263)

Industry (1047)

Information (497)

Insects (48)

Insurance (240)

International Atomic Energy Agency (IAEA) (8)

International Civil Aviation Organization (ICAO) (4)

International Court of Justice (ICJ) (17)

International Labour Organisation (ILO) (12)

International organizationsInstitutions (301) 
International

Telecommunication

Union (ITU) (4)

Investments (1403)

Judicial matters (530)

Kyoto Protocol (11)

Labour (1950)

Latin America (73)

Law of the Sea (133)

Law of Treaties (29)

League of Nations (7)

Legal matters (1291)

Lend-lease agreements (68)

Loans (7125)

Mano River Union (19)

Maritime matters (463)

Marketing (79)

Metals (70)

Meteorology (26)

Middle East (57)

Migration (317)

Military matters (2576)

Mines (military) (72)

Mining (124)

Missions; see also United Nations Missions-

Peacekeeping (56)

Monetary matters (347)

Motor vehicles (100)

Mutual relations (509)

Narcotics (385)

Nationality (84)

NATO (49)

Natural resources (242)

Navigation (807)

Neutrality (6)

Non-proliferation of nuclear weapons (38)

Nordic countries (4)

North America (10)

North Atlantic Organization (42)
Nuclear matters (855)

Offices (212)

Outer space (280)

Pacific (107)

Passports (1111)

Patents (70)

Payments (552)

Peace (359)

Penal matters (10)

Pensions (161)

Petroleum (143)

Planning (77)

Plants (111)

Police (85)

Pollution (94)

Population (258)

Ports (253)

Postal services (438)

Privileges-Immunities (285)

Professions (86)

Property matters (469)

Public works (159)

Publications (84)

Railway (26)

Refugees (95)

Regional cooperation (73)

Religion (14)

Rescue (53)

Research (631)

Roads (1472)

Sanitation (364)

Sciences (547)

Scientific matters (1710)

Sea (202)

Security (241)

Services (428)

Ships and shipping (623)

Social matters (1460)

Soils (17)

South America (3)

Treaty South Pacific (2)

(NATO) Southeast Asia (6)
Specialized agencies; see also names of agencies (12)

Sports (55)

Statistics (62)

Taxation (2177)

Telecommunications (1001)

Territories (195)

Terrorism (41)

Tourism (413)

Trade (4955)

Trade law (24)

Trade-marks and appellations of origin (61)

Transport (4891)

Treaties-Agreements (application) (96)

Trust territories; see also Territories (34)

United Nations (UN) (638)

United Nations Children's Fund (UNICEF) (164)

United Nations Development Programme (UNDP) (16)

United Nations Industrial Development Organization

(UNIDO) (20)

United Nations MissionsPeacekeeping (150)

Volunteers (167)

War (196)

Watercourses-Water resources (1499)

Whaling (19)

Wildlife (protection) (26)

Wines-Spirits (15)

Women (72)

World Health Organization (WHO) (5) 
Anexo III - Lista de atores e quantidades de tratados no banco de dados do World Treaty Index (1900-2000).

\begin{tabular}{|c|c|}
\hline AAEA (1) & Bahamas (43) \\
\hline AARRO (2) & Bahrain (36) \\
\hline Abu Dhabi (5) & Balkan Ent. (1) \\
\hline ACTC (5) & Union of Banana Exporting \\
\hline ADB (5) & Countries (1) \\
\hline ADBNK (46) & Bangladesh (479) \\
\hline $\mathrm{ADC}(4)$ & Barbados (75) \\
\hline Aden (2) & BDCAS (1) \\
\hline $\mathrm{ADF}(2)$ & BECHUA (1) \\
\hline A-E Sudan (1) & Belarus (39) \\
\hline AEIB (1) & Belgium (1393) \\
\hline AFBNK (14) & Belgium- belg. Congo (1) \\
\hline AFENT (1) & Belgium- Rwanda (1) \\
\hline Afghanistan (271) & Belize (30) \\
\hline AFGRO (1) & Benin (218) \\
\hline AFINS (1) & Bermuda (1) \\
\hline AFIPO (1) & Bhutan (24) \\
\hline $\operatorname{AFMCOF}(1)$ & BIS (2) \\
\hline African Coffee Organization & BLEGIU (1) \\
\hline (2) & Benelux (169) \\
\hline AFSAH (2) & Bolivia (Plurinational State \\
\hline AFSED (1) & of) (1106) \\
\hline AIEC (3) & Bosnia and Herzegovina (32) \\
\hline AJMAN (1) & Botswana (139) \\
\hline Albania (435) & Brazil (2318) \\
\hline Algeria (373) & Brit. Guiana (2) \\
\hline ALO (1) & Brit. Honduras (1) \\
\hline AMBASS. CONF. (4) & Brit. India (32) \\
\hline Andorra (6) & Brunei Darussalam (12) \\
\hline Angola (72) & Bulgaria (1220) \\
\hline Antigua and Barbuda (14) & Burkina Faso (210) \\
\hline AOMR (1) & Burundi (124) \\
\hline $\mathrm{AP}(4)$ & BYELOR (2) \\
\hline APNWLA (2) & CABNK (8) \\
\hline Arabe League (8) & Cambodia (2) \\
\hline Argentina (1597) & Cambodia (166) \\
\hline Armenia (31) & Cameroon (248) \\
\hline ASCENS (1) & Canada (1482) \\
\hline ASEAN (3) & Cape Verde (103) \\
\hline Asian Bank (1) & CARBNK (20) \\
\hline ASPRO (2) & CARCTY (2) \\
\hline Australia (831) & CARDI (1) \\
\hline Austria (1500) & CASDB (1) \\
\hline Azerbaijan (23) & CBWAS (1) \\
\hline
\end{tabular}

CCAMLR (2)

CEC (5)

Central African Republic (133)

Central-American

Commission on

Environment and

Development (2)

CEPGL (1)

CERN (8)

Chad (147)

Chile (657)

China (2639)

CIAT (1)

CLEUR (4)

COIRT (1)

Colombia (635)

COMAGB (3)

COMFON (1)

COMFUN (2)

Commission for The Conservation Of Southern Bluefin Tuna (1)

COMOL (1)

Comoros (37)

COMSEC (1)

COMTEL (2)

Congo (158)

Cook Islands (14)

Costa Rica (267)

Cotte D'Ivoire (278)

Croatia (36)

CTBTO (1)

Cuba (736)

Curacao (2)

CUSTOM (1)

Cyprus (260)

Czech Republic (16)

Czechoslovakia (1395)

DANZIG (6)

Democratic People's

Republic of Korea (926)

Democratic Republic of the Congo (233) 


\begin{tabular}{|c|c|c|}
\hline \multirow{2}{*}{$\begin{array}{l}\text { Dem } \\
\text { Den }\end{array}$} & & \multirow{2}{*}{$\begin{array}{l}\operatorname{ICAC}(3) \\
\operatorname{ICC}(2)\end{array}$} \\
\hline & EXHIBI (3) & \\
\hline Djibouti (48) & EXIMBK (2) & $\operatorname{ICCAT~(1)~}$ \\
\hline Dominica (50) & Republic & $\operatorname{ICCEC~(1)~}$ \\
\hline Dominican Republic (223) & Germany (4035) & ICCROM (2) \\
\hline Dubai (1) & Fiji (90) & $\operatorname{ICDCS}(2)$ \\
\hline EAC (9) & Finland (1326) & $\operatorname{ICDO}(2)$ \\
\hline EAFC (6) & FONPLA (1) & Iceland (363) \\
\hline East Atlantic & Food and & ICES (1) \\
\hline Commission (1) & Organization (138) & $\operatorname{ICITO}(2)$ \\
\hline EBRD (2) & Fr. Indochina (6) & ICJ (1) \\
\hline ECMWF (3) & France (4274) & ICMPD (1) \\
\hline ECPTA (2) & French Equatorial Africa (1) & ICO (4) \\
\hline $\operatorname{ECSC}(12)$ & FRHOD (14) & $\operatorname{ICOCO}(1)$ \\
\hline Ecuador (538) & FUJAIR (1) & ICOTIN (2) \\
\hline EEA (1) & Gabon (143) & $\operatorname{ICWM}(2)$ \\
\hline EEC (203) & Gambia (135) & IDA (3276) \\
\hline EFTA (2) & Georgia (43) & IDBNK (2) \\
\hline Egypt (977) & Democratic & IFC (8) \\
\hline El Salvador (278) & Republic (2294) & IHO (1) \\
\hline ELDO (7) & Germany (Unified) (558) & $\operatorname{IIR}(1)$ \\
\hline EMBL (4) & GERMU (523) & IIUPL (1) \\
\hline EPO (8) & Ghana (388) & ILZ (3) \\
\hline EPPO (2) & Gibraltar (1) & $\operatorname{IMCO}(18)$ \\
\hline Equatoral Guinea (64) & Greece (968) & IMSO (1) \\
\hline Eritrea (18) & Grenada (29) & India (2094) \\
\hline ESRO (30) & Guatemala (298) & Indonesia (843) \\
\hline Estonia (338) & Guinea (276) & INFISH (1) \\
\hline Ethiopia (350) & Guinea Bissau (86) & INTEA (1) \\
\hline EUI (1) & GULFCC (2) & Inter-American Institute For \\
\hline EURAT (22) & Guyana (140) & Global Change Research \\
\hline EURCOM (10) & Hague Conference on Private & (1) \\
\hline EURCON (9) & International Law (4) & Intergovernmental Authority \\
\hline EURIB (1) & Haiti (227) & On Development (3) \\
\hline European Communities And & HEDJAZ (4) & International Atomic Energy \\
\hline Their Member States (2) & Holy See (1) & Agency (247) \\
\hline European Monetary Institute & Honduras (252) & International \\
\hline$(1)$ & Hong Kong (43) & Reconstruction \\
\hline European & Hungary (1297) & Development (4363) \\
\hline Recreational & IAAGR (9) & International Civil Aviation \\
\hline Industry & IABNK (90) & Organization (37) \\
\hline (International Council of & IANEC (1) & International Fund \\
\hline Industry & IAOE (1) & Agricultural Development \\
\hline Associations) (11) & IAOSS (1) & $(426)$ \\
\hline EURSAG (11) & IBA (1) & International \\
\hline EURSCH (2) & $\operatorname{IBE}(2)$ & Organization (107) \\
\hline EURTEL (2) & IBI (2) & \\
\hline
\end{tabular}


International Monetary Fund (7)

International

Telecommunication Union (17)

INTPEP (1)

IOEPIZ (1)

IOLM (2)

IOOC (2)

IOPC (2)

IPI (1)

IPOESA (1)

IPU (2)

Iran (Islamic Republic of) (636)

Iraq (336)

Ireland (324)

IRO (3)

IRSG (1)

IRTO (4)

IRU (1)

ISLAM (4)

ISNAR (1)

ISO (3)

Israel (813)

Italy (1906)

ITC (1)

ITSO (2)

ITTO (1)

IUPIP (1)

IUSCT (1)

IWC (1)

IWHAC (1)

Jamaica (236)

Japan (1854)

Jordan (353)

JVI (1)

Kazakhstan (45)

Kenya (458)

KFAD (1)

Kiribati (10)

Kuwait (98)

Kyrgyzstan (27)

LACP (1)

LACRIM (1)

LAES (5)

LAFSS (1)
Lao Peoples Democratic NASCO (1)

$$
\text { Republic (178) Nauru (13) }
$$

Latin American Free Trade NEJD (1)

$$
\text { Association } \tilde{A}, \hat{A} \text { (4) Nepal (301) }
$$

LATUN (1)

Latvia (266)

Netherlands (1617)

LCBC (1)

Nevis (1)

New Zealand (452)

LEAGUE (9)

NEWFOU (3)

Lebanon (281)

Nicaragua (259)

Lesotho (112)

Niger (243)

Liberia (198)

Nigeria (300)

Libyan Arab Jamahiriya Niue (1) (144)

NORSAD (1)

NORSAF (1)

Liechtenstein (54)

North Atlantic Treaty

Lithuania (226)

Organization (16)

LPBC (1)

Luxembourg (307)

Macao (10)

Madagascar (243)

Malawi (242)

Malaysia (305)

Maldives (30)

Mali (307)

Malta (144)

Manchukuo (1)

MANOR (3)

Marshall Islands (3)

Martinique (2)

Mauritania (229)

Mauritius (106)

Mexico (1155)

Micronesia Federated States of (1)

MIGA (74)

Monaco (116)

Mongolia (438)

Montenegro (1)

Morocco (614)

Mozambique (146)

North Viet Nam (438)

Norway (1312)

NPMSO (1)

NRHOD (2)

OCAS (2)

ODSR (4)

Oman (57)

OPECF (2)

Organisation for Economic Cooperation and Development (16)

Organisation of African Unity (17)

Organization of American States (24)

Organization of the Petroleum Exporting Countries (3)

ORMAL (2)

Pakistan (863)

Palau (8)

Panama (286)

Papua New Guinea (87)

Paraguay (464)

Multinational Force and PASAN (21) Observers (11)

Multinational Force And Peru (692) Observers (1)

MUSCAT (14)

Myanmar (265)

Namibia (27)
PATU (1)

Philippines (827)

PLO (4)

Poland (1756)

Port. India (3) 
Portugal (833)

Qatar (25)

RAKHAI (1)

REDCRO (4)

Relief Bonds (1)

Republic of China (189)

Republic of Korea (962)

Republic of Moldova (37)

Republic of Palau (1)

Rhineland C. (1)

RNAVI (1)

Romania (1329)

Russian Federation (191)

Rwanda (148)

SAAR (14)

SABAYA (1)

SAFRI (270)

Saint Kitts and Nevis (11)

Saint Lucia (40)

Saint Vincent and the Tajikistan (14) Grenadines (22)

Samoa (20)

San Marino (58)

Sao Tome and Principe (50)

SATO (1)

Saudi Arabia (156)

SCAPJ (10)

SEATO (2)

SECAB (1)

Secretariat

Of

Convention On Biological Diversity (1)

Senegal (399)

Serbia (8)

Seychelles (39)

SHARJA (1)

SIECA (2)

Sierra Leone (204)

Singapore (328)

Slovakia (39)

Slovenia (48)

Socialist Federal Republic of Yugoslavia (1643)

Solomon Islands (25)

Somalia (184)

Soth Viet Nam (204)
South African Development UNCHS (1)

Community (9)

Southern Rhodesia (3)

SOVEC (10)

$\operatorname{UNEP}(19)$

SOVRR (1)

SPACI (4)

Spain (2755)

Span. Guinea (1)

SPFFA (1)

Sri Lanka (490)

STCRI (1)

STRAITS (3)

Sudan (289)

Suriname (76)

Swaziland (71)

Sweden (2049)

Switzerland (1385)

Syrian Arab Republic (554)

TAB (11)

Tanganyika (22)

TECAG (2)

Thailand (517)

The former Yugoslav Republic of Macedonia (31)

Tibet (1)

Timor-Leste (0)

TJIKI (1)

TJORD (4)

Togo (256)

Tonga (35)

Trans- Jordan (2)

Triest (3)

Trinidad and Tobago (114)

Tunisia (591)

Turkey (1097)

Turkmenistan (17)

Tuvalu (11)

UAQAIW (1)

Uganda (185)

UIPI (1)

Ukraine (96)

Un Economic Commission For Africa (1)

UN University (1)

UNCDF (165)
UNESCP (11)

UNFDAC (1)

UNFNRE (27)

UNFPA (7)

Union of Soviet Socialist Republics (2997)

United Arab Emirates (31)

United Kingdom of Great Britain and Northern Ireland (3658)

United Nations (1121)

United Nations Children's Fund (262)

United Nations Conference on Trade and Development (7)

United Nations Development Programme (342)

United Nations Disaster Relief Coordinator (18)

United Nations Economic Commission for Latin America and the Caribbean (63)

United Nations Educational Scientific and Cultural Organization (UNESCO) (67)

United Nations High Commissioner for Refugees (44)

United Nations Industrial Development Organization (153)

United Republic of Tanzania (454)

United States of America (7775)

Universal Postal Union (8)

UNJSPF (11)

UNKRA (2)

UNRRA (5)

UNRWA (24)

UNTAG (1)

UPEACE (2) 


\begin{tabular}{|c|c|c|}
\hline Upper Volta (13) & WAFDB (4) & Meteorological \\
\hline Uruguay (564) & WAFMU (1) & Organization (19) \\
\hline Uzbekistan (46) & WARDA (1) & World Trade Organization \\
\hline Vanuatu (18) & WEU (6) & (WTO) (9) \\
\hline Vatican (114) & WINDI (1) & WSAMO (30) \\
\hline Venezuela & Winward Is. (1) & Yemen Arab Republic (15) \\
\hline Republic of (479) & World Food Programme (7) & Yemen (223) \\
\hline Viet Nam (36) & World Health Organization & Zambia (249) \\
\hline VINE (2) & $(306)$ & Zanzibar (2) \\
\hline West Allies (1) & World Intellectual Property & Zimbabwe (101) \\
\hline WAEC (2) & Organization $(20)$ & \\
\hline WAFDA (1) & & \\
\hline
\end{tabular}

Anexo IV - Lista de assuntos relacionados suas descrições, e quantidades de tratados, no banco de dados do World Treaty Index (1900-2000). Baseado em "Peter Rohn's Topic Thesaurus"' (disponível em http://worldtreatyindex.com/topic_fields.pdf)

Nota: Neste banco de dados cada tratado é relacionado a somente um assunto, logo a soma das quantidades de todos é exatamente o total de tratados.

Alliance (1ALLY); Quantidade (133); Descrição: Military alliances, possibly including non-military matters.

Amity (1AMITY); Quantidade (1352); Descrição: Friendship, general relations, and matters concerning more than one topic in the Topic Group

Arms Control (1ARMCO); Quantidade (204); Descrição: Arms control and disarmament, including safeguards for operation of nuclear reactors.

UN Membership (1CHART); Quantidade (0); Descrição: Acceptance of obligations of UN charter.

Dispute Settlements (1DISPU); Quantidade (492); Descrição: Formal procedural and substantive resolutions of legal and political controversies.

IGO Establishment (1ESTAB); Quantidade (420); Descrição: Establishment of an international government organization (IGO).

IGO Headquarters (1HEAD); Quantidade (246); Descrição: Establishment of an IGO headquarters, and relations between it and the host country.

Military Occupation (1OCCUP); Quantidade (17); Descrição: Belligerent occupation.

International Court of Justice Clause (1OPTC); Quantidade (0); Descrição: Acceptance of compulsory jurisdiction of the International Court of Justice(ICJ). Treaties entered under this topic are all Unilateral.

Peace/Armistice (1PEACE); Quantidade (100); Descrição: Termination of war or hostilities.

Diplomacy/Recognition (1RECOG); Quantidade (569); Descrição: Diplomatic relations and recognition, independence of new states,acceptance of treaty obligations.

Reparations (1REPAR); Quantidade (214); Descrição: Post-war reparation settlements. These are on a global or country-to-country level, and would often involve one country giving another country some lump sum of money to pay for damages. 
Status of Forces (1STATU); Quantidade (156); Descrição: Peacetime status of foreign military forces.

Territorial Limits (1TERRI); Quantidade (494); Descrição: National land and water boundaries determined by political decisions.

UN Trusteeship (1TRUST); Quantidade (14); Descrição: Establishment or operation of a UN trusteeship. Does not involve money in trust.

General Welfare (2HEW); Quantidade (109); Descrição: Matters concerning more than one topic in this group.

Relief/Rescue (2HUMAN); Quantidade (133); Descrição: Humanitarian relief and rescue relating to shipwrecks, floods, earthquakes and other disasters. These involve short-term assistance for particular disasters that have occurred.

Labor (2LABOR); Quantidade (363); Descrição: Includes migratory labor, trade unions, and internships.

Narcotics Control (2NARK); Quantidade (216); Descrição: Control of illegal drug production and traffic.

Refugees (2REFUG); Quantidade (90); Descrição: Refugees and repatriation.

Human Health (2SANIT); Quantidade (465); Descrição: Disease control, public health, projects or techniques to aid public health and sanitation.

Social Security (2SECUR); Quantidade (922); Descrição: Social security, retirements, old age benefits, disability, unemployment compensation.

Status of Women (2WOMEN); Quantidade (22); Descrição: Legal status of women and issues of women's equality.

Claims, Debts, Assets (3CLAIM); Quantidade (1147); Descrição: Claims regarding particular debts and assets, mainly concerning retrospective settlement. Claims for damages are analogous to a US suit for damages.)

Raw Materials Trade (3COMMO); Quantidade (674); Descrição: Trade in specific commodities, e. g. aluminum, cotton, rubber, fish, meat, phosphates, wool.

Customs Duties (3CUSTO); Quantidade (539); Descrição: Custom rates and tariffs.

Economic Cooperation (3ECON); Quantidade (1327); Descrição: General economic cooperation and matters not covered elsewhere, or concerning more than one topic in Topic Group 3.

Industry (3INDUS); Quantidade (157); Descrição: Factories or entire industrial sectors.

Investment Guarantee (3INVES); Quantidade (843); Descrição: General guarantees for protection of investments.

Most Favored Nation Status (3MOSTF); Quantidade (87); Descrição: Traditional mostfavored nation treatment as the main function of a treaty, rather than as an incidental clause.

Patents and Copyrights (3PATEN); Quantidade (356); Descrição: Patents, copyrights, trademarks, intellectual property.

Payments and Currency (3PAYMT); Quantidade (1147); Descrição: Routine commercial payments and exchange rates. 
Products and Equipment (3PROD); Quantidade (456); Descrição: Finished goods, industrial products, equipment, facilities, installations, commercial as well as military.

Taxation (3TAXAT); Quantidade (1759); Descrição: Double taxation, tax exemptions, fiscal evasion.

Technical Cooperation (3TECH); Quantidade (1411); Descrição: Technical and scientifictechnological cooperation and exchange between equally developed nations.

Tourism (3TOUR); Quantidade (291); Descrição: Promotion of tourism.

General Trade (3TRADE); Quantidade (3709); Descrição: Trade not limited to any particular commodity.

Trade and Payments (3TRAPA); Quantidade (825); Descrição: Equal or similar emphasis on both.

Food or Agricultural Aid (4AGRIC); Quantidade (3066); Descrição: Aid for foodstuffs, fertilizers, and agricultural products, equipment, and techniques. These projects are typically short-term: they have a limited lifespan.

Unspecified Aid (4AID); Quantidade (879); Descrição: Aid concerning more than one topic in topic group, or which does not fall into other topics.

Atomic Energy Aid (4ATOM); Quantidade (16); Descrição: Aid for peaceful use of nuclear energy.

Educational Aid (4EDUC); Quantidade (1036); Descrição: Aid for academic and vocational training.

Financial Aid (4LOAN); Quantidade (6299); Descrição: Loans and other repayable financial aid, including World Bank projects; financial cooperation between developed and developing nations. Loans for purposes represented by other topics are classified under those topics, e.g. 4MILIT for loans for military equipment.

Medical Aid (4MEDIC); Quantidade (580); Descrição: Aid for hospital construction and equipment, as well as organization of public health services.

Military Aid (4MILIT); Quantidade (638); Descrição: Aid for military supplies, equipment, training.

Peace Corps or other Volunteers (4PCOR); Quantidade (174); Descrição: American Peace Corps and similar volunteer services of donor countries, e.g. European volunteers, Japanese volunteers.

Resources Aid (4RESOU); Quantidade (3278); Descrição: Aid for the build-up of infrastructures to develop national resources.

Technical Assistance (4TECA); Quantidade (1851); Descrição: Non-financial aid through advisory services for modernization, chiefly short-term assistance projects. Do not use this topic for development credits. Between IGO/developed nation and developing nation.

UNICEF Aid (4UNICE); Quantidade (198); Descrição: Aid involving UN Children's Fund.

Air Transport (5AIR); Quantidade (2692); Descrição: Air services, airlines, airports, landing rights.

Land Transport (5LAND); Quantidade (942); Descrição: Road and rail transport including passengers, freight, bridges, tunnels 
General Transport (5TRANS); Quantidade (85); Descrição: Matters concerning more than one topic in this topic group.

Water Transport (5WATER); Quantidade (762); Descrição: Ocean, lake, river transport including passengers, freight, ports.

Communications (6COMMU); Quantidade (173); Descrição: General communications; matters concerning more than one topic in topic group.

Mass Media (6MEDIA); Quantidade (412); Descrição: Newspapers, radio, television, exchange of newsreels.

Postal Services (6POST); Quantidade (637); Descrição: Rates and handling procedures for letters, parcels, and postal money orders.

Telecommunications (6TELCO); Quantidade (542); Descrição: Telephone and telegraph services, construction and operation of radar stations, allocation of frequencies.

Culture (7CULT); Quantidade (2348); Descrição: Theater, opera, ballet, films, books, sports; as well as matters concerning more than one topic in this topic group.

Education (7EDUC); Quantidade (485); Descrição: Student and teacher exchange, joint schools and programs, equivalence of degrees and diplomas, cooperation in educational projects. Primary emphasis on teachers/students from kindergarten to Ph.D.

Religion (7RELIG); Quantidade (58); Descrição: Not limited to any particular religion, but with religion as the primary focus of the treaty.

Science and Technology (7SCIEN); Quantidade (781); Descrição: Research programs and exchanges in science and technology, weather stations, earth and ocean observations, cooperation between academies of science.

Seminars and Conferences (7SEMIN); Quantidade (525); Descrição: UN sponsored and other seminars and conferences on specific issues. Typically treaties between the UN group and a host country.

Space Exploration and Research (7SPACE); Quantidade (203); Descrição: Peaceful uses of outer space and related space technology, including satellites and orbital stations.

Agriculture (8AGRIC); Quantidade (260); Descrição: Fertilizer, experimental programs, pest and disease control, quarantine.

Cattle or Fowl (8CATTL); Quantidade (238); Descrição: Veterinary matters, vaccination, health certificates, crossboundary grazing, migratory birds.

Energy (8ENERG); Quantidade (677); Descrição: All forms of energy.

Environment or Ecology (8ENVIR); Quantidade (175); Descrição: Pollution control, wildlife protection by species or region, water quality, environmental

Fisheries (8FISH); Quantidade (585); Descrição: Fish and all other living marine animals as resources. Conditions and ones of conservation and harvesting.

Metallurgy (8METAL); Quantidade (92); Descrição: Mining and processing of metals as natural resources.

Water (8WATER); Quantidade (143); Descrição: Multiple use of water, e.g. irrigation, power, drinking. 
Wood or Forestry (8WOOD); Quantidade (39); Descrição: Forestry management, reforestation, logging, fire protection.

Administration (9ADMIN); Quantidade (1248); Descrição: Routine matters that don't fit into any other Topic or that concern more than one Topic in this Topic Group. Arrangements between IGOs to handle projects.

Boundary Maintenance (9BOUND); Quantidade (346); Descrição: Physical maintenance and marking of borders, e.g. bridges, tunnels, checkpoints, mapping.

Nationality or Aliens (9CITIZ); Quantidade (268); Descrição: Immigration, citizenship, nationality, minorities, military service requirements.

Consulates (9CONSU); Quantidade (738); Descrição: Consular matters including functions, buildings. Also includes business being transacted at the diplomat/consul level.

Legal Procedures (9LEGAL); Quantidade (1049); Descrição: Judicial assistance, enforcement of civil and criminal judgements.

Military Procedures (9MILIT); Quantidade (842); Descrição: Routine military cooperation between equivalent countries

Military Missions (9MILMI); Quantidade (123); Descrição: Permanent military missions.

Privileges and Immunities (9PRIVI); Quantidade (277); Descrição: Diplomatic immunities of governments and international organizations.

Visas and Passports (9VISAS); Quantidade (2004); Descrição: Visas and visa fees, regulation of movement of persons and goods across borders.

Extradition (9XTRAD); Quantidade (582); Descrição: Extradition and deportation. 